\title{
Why Monarchy?
}

\section{The Rise and Demise of a Regime Type}

\section{Contents}

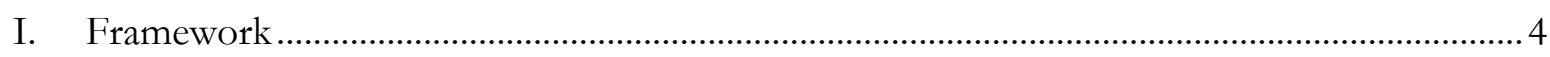

Legitimacy

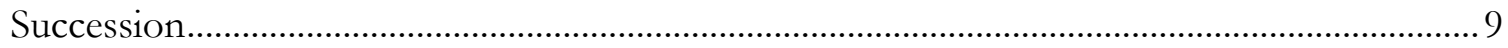

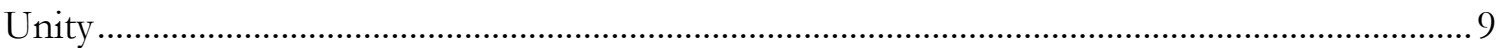

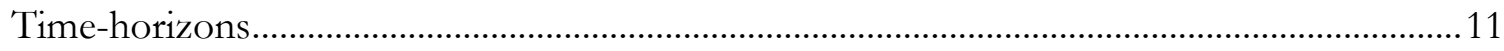

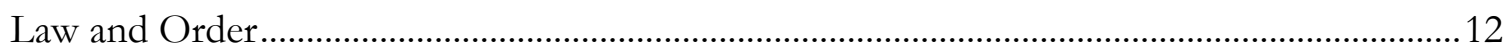

The Demise of Monarchy ……………………………………………………………….....14

II. Concept and Measure.........................................................................................................

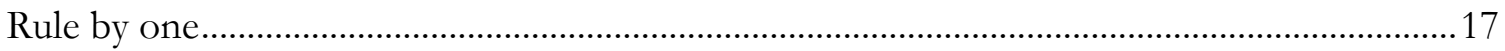

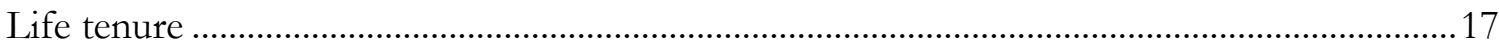

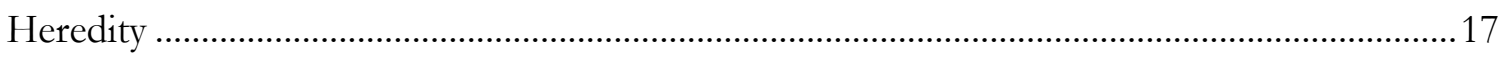

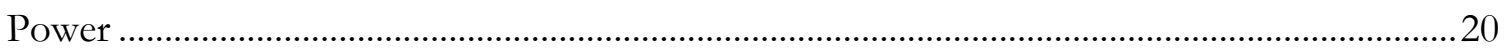

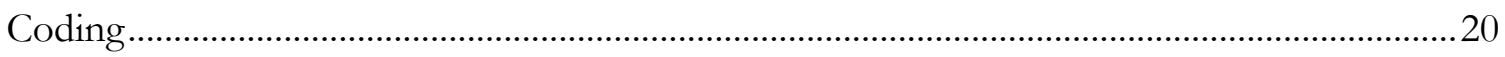

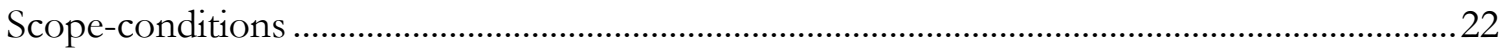

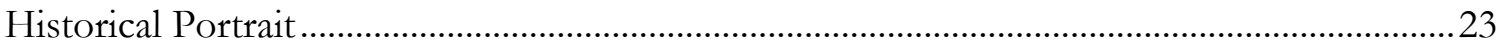

III. Hypotheses and Analyses .............................................................................................26

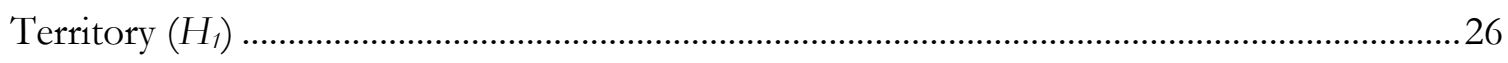

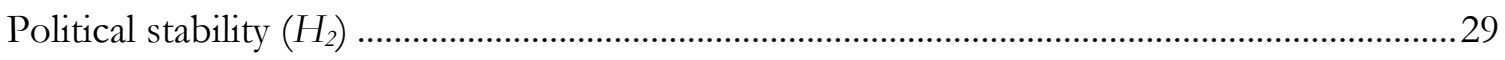

Tenure in office $\left(H_{3}\right)$..................................................................................................

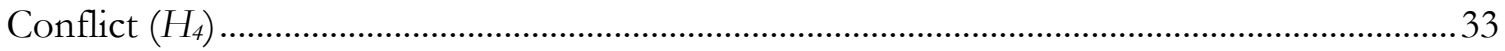

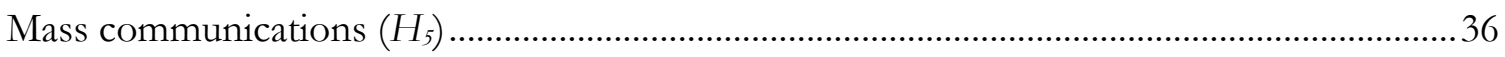

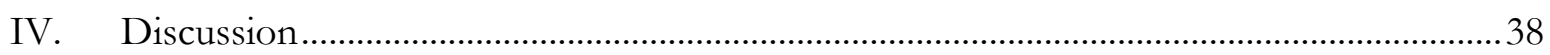

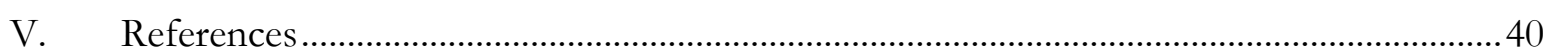

Appendix A: Alternatives to Monarchy in the Pre-Modern Era ......................................................47

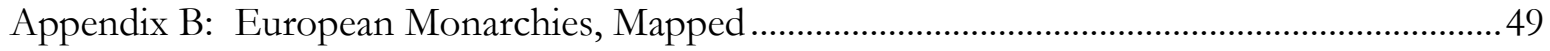

Appendix C: Global Monarchies, Mapped ……………………………………………………......61

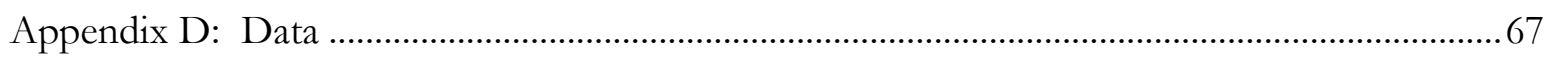

Appendix References...................................................................................................................72 
If one were able to catalog rulers of state-like polities from the beginning of human civilization to the present one sort of ruler would predominate among all others. Monarchy, in one form or another, has a storied history in every region of the world. The first rulers, as recorded in the first written texts, were usually monarchs, who passed down their title from generation to generation within the same family. ${ }^{1}$

Today, this once-dominant regime type has fallen on hard times. To the extent that hereditary rulers persist they are likely to be displaced by other actors who exercise executive power in their stead. Only a handful of monarchs retain their titles and their prerogative - in Bahrain, Bhutan, Brunei, Jordan, Kuwait, Liechtenstein, Monaco, Morocco, Oman, Qatar, Saudi Arabia, Swaziland, Tonga, and United Arab Emirates.

Yet, the question of monarchy remains central to our understanding of how political power is generated and regenerated through history. According to one venerable intellectual tradition, political history is the history of monarchs and their dynasties, who played a principal role in the success or failure of the nations they ruled. In the modern era, Menaldo (2012) argues that monarchies are less prone to instability than other forms of government. The influence of monarchy resonates even in countries where hereditary executives no longer rule or no longer exist (McDonagh 2015). Since monarchy is the usual precursor to democracy and non-monarchic varieties of autocracy it is also central to our understanding of regime-change.

Helpfully, a gigantic library of work by anthropologists, archaeologists, historians, political scientists, and sociologists chronicles the rise and fall of dynasties and the inner workings of monarchies around the world (Duindam 2016). A smaller body of studies center on monarchical tenure and succession (e.g., Kokkonen, Sundell 2014). Even so, there is no well-developed theory that might explain the rise and near-demise of monarchy.

One may infer that ideational factors loomed large. Historical sources suggest that monarchs once commanded a great deal of legitimacy. Over time, as reverberations from the age

\footnotetext{
${ }^{1}$ A longer version of this article, with citations to an immense historical literature, is available upon request.
} 
of revolutions and enlightenment diffused, monarchy lost its sanctity and allure. By the late twentieth century, monarchies seemed at odds with modern forms of political legitimacy (Huntington 1966). But why did attitudes toward this ancient regime type change so profoundly over the past two centuries? Why did the bases of legitimacy shift? Distal factors are more elusive.

One may regard the decline of monarchy as the end-product of a seismic sociological shift. As the basis of socioeconomic status shifted from birthright to merit, a system of rule based entirely on inheritance came to seem anachronistic (Wolf 1991: 255-57). Accordingly, one would expect that measures of socioeconomic development and overall modernization such as per capita GDP would predict the fall of monarchy. Yet, we find no such correlation in our empirical analyses. Indeed, the monarchies that persist tend to be richer and more developed than republics in their respective regions.

Conceivably, the decline of monarchy is linked to the decline of autocracy over the past two centuries. While there may be some truth to this narrative, one must also bear in mind the persistence of autocratic forms of rule in the twenty-first century under other guises - military, personal, or partisan (e.g., Ezrow, Frantz 2011). If autocracy survives while monarchy perishes, this suggests that the two developments are not closely linked.

To account for monarchical survival in the dozen or so countries where a hereditary ruler still wields effective power scholars have invoked a variety of factors including cultural characteristics specific to the Middle East (Lewis 2000), political leadership (Kechichian 2001), Ottoman and/or British influences (Ayalon 2000), Islam (Karawan 1992), oil rents (Gause 1994), international security concerns (Gause 2000), the imperatives of statebuilding (L. Anderson 1991), institutionalization (Lucas 2012), and the ability of royal families to successfully manage transitions (Herb 1999). While plausible, these narrowly focused explanations do not purport to provide a general account of the decline - and occasional resilience - of monarchy. 
The goals of this paper are severalfold. First, we propose a theory intended to explain both the rise of monarchy to global dominance and its subsequent near-demise. Second, we offer a definition of this vexed term, focusing on the most distinctive and consequential aspects of the regime type, and a binary index of monarchy that is coded across polities in Europe back to 1000 and throughout the world back to 1700 - an original dataset of unparalleled scope, which we use to track the rise and fall of monarchy in Europe and the world. Finally, we use this data to test a set of hypotheses intended to corroborate the theory.

\section{Framework}

A monarchy, for present purposes, is a polity with an executive office that is (a) hereditary, (b) held by a single individual, (c) endowed with life tenure, and (d) of non-trivial importance in running the affairs of state. So defined, state-like forms of political organization around the world from Mesopotamia to the present may be classified as monarchical or republican. (Further discussion of conceptualization and measurement is taken up in the next section.)

Within this expansive frame, we hope to explain why monarchy became the dominant regime type in the pre-modern era and why it fell from grace in the modern era (beginning, following convention, with the French Revolution). One might be skeptical of a framework that purports to encompass such a large expanse of time and space. However, we shall argue that the rise and decline of monarchy is closely linked. Accordingly, we gain theoretical and empirical leverage by examining the entire life-history of this unique regime type.

We begin with the leaders of states, who play a key role in our theory. The desire of parents to install offspring as their successors presumably stems from a biological propensity to propagate one's genetic heritage (Dawkins 1978). By passing down power and wealth to one's children (the most common pattern of succession) a ruler perpetuates his lineage. In this light, monarchy is a particular form of inheritance system, designed to assure the smooth transfer of 
property so that a family's wealth and status is preserved across generations (Goody, Thirsk, Thompson 1979). Note that property is regarded as belonging not to the individual but to the royal family, or "house." Arguably, all political leaders aspire to be monarchs, just as all parents aspire to bequeath power, status, and wealth to their children.

Evolutionary theory may explain the behavior of leaders, who are well-positioned to influence the selection of their successor. However, whether this dynastic venture is successful or not depends upon those outside the royal family, who must support the family's birthright.

To explain the behavior of non-royals we presume that they, like royals, would prefer to rule - or at least to have a hand in controlling the ruler. However, they may be willing to relinquish this ambition if monarchy promises a more effective solution to the problem of order than other systems currently available, thus promising to preserve their lives, property, and status. The question, then, is why monarchy may have provided an efficient solution to the problem of order in some periods but not in others.

Where the scale of human societies is small - in bands, tribes, or villages - public order may be achieved through a variety of formal and informal institutional arrangements (Crone 1989). (We exclude such non-state entities from our theoretical purview, as discussed below.) As the scale of a society grows, coordination challenges multiply and are solvable only where there is a single locus of sovereignty.

In any society, there will be many aspirants for the position of sovereign. Moreover, the choice among them is highly consequential. Those allied with the winner are likely to prosper; those allied with the loser may find their fortunes impaired and their lives endangered. A good deal is at stake in the outcome of a contest for leadership. Nonetheless, a leader or leadership group must be chosen, and their authority respected, lest society dissolve into anarchy. In order to establish sovereignty everyone, or most everyone, must agree on where that locus of authority resides. 
We argue that a monarchical system of rule is best equipped to solve this coordination dilemma in disconnected societies, where obstacles to coordination are greatest. This explains its appeal in the pre-modern world, where most citizens were illiterate, spoke a babble of tongues, rarely encountered those outside their locality, and consequently had little sense of belonging to a larger community (Crone 1989). These features, in turn, were by-products of the diffuseness of human settlement, poor communications and transportation infrastructure, and languages that were unwritten or largely untaught. For these reasons, populations in pre-modern societies were not closely interconnected and the flow of information was glacial. In a disconnected society of this sort, monarchy offered a workable solution to society's coordination problem.

As societies became more interconnected other methods of leadership selection became more viable. The muteness of monarchy, its self-evident but non-negotiable quality, became a detriment in an age of mass communications when ordinary citizens were easily reached and mobilized. This explains its demise in the modern age.

To recapitulate, monarchy offers an efficient solution to the primordial problem of order where societies are large - requiring a state-like form of organization - and citizens isolated from each other. Its efficiency is challenged by other methods of leadership selection when barriers to communication are removed.

We begin by laying out the advantages of monarchy in a pre-modern setting - namely, a sovereign who could claim: (a) political legitimacy, (b) orderly succession, (c) unity, (d) long timehorizons, and (e) the ability to impose law and order. Supplementing this discussion, Appendix A offers a brief review of the alternatives to monarchy in the pre-modern era. Next, we discuss the demise of monarchy in the modern era. 


\section{Legitimacy}

Effective governance depends upon legitimacy - the idea that a ruler exercises rightful authority. In establishing legitimacy, monarchs were able to draw upon diverse strands of "traditional" authority (Weber 1904-05/1958), which they also re-invented and perpetuated.

To begin with, monarchs descended from royalty, a claim that could be enhanced and embellished in a variety of ways. Royal scribes worked hard to establish the bloodlines of the royal family, extending all the way back to a founding ruler or god. Since the official historical record was usually in the hands of the king's men this left plenty of room for myth-making. From this followed a tradition of meticulous - even obsessive - genealogy (Parker 2011: 365-67; Sutherland 2001).

Royal legitimacy rested, second, upon scrupulous attention to the distinctiveness of the king, who occupied a position separate and apart from everyone else. This status was sanctioned by special forms of address, special architecture, and special crowns, scepters, stools, seals, crests and other regalia - a vast assemblage of royal bling. Dynastic founders often came from somewhere else, generating the myth of the stranger-king (Duindam 2016: 44). Royal families were physically isolated from the citizenry. The Japanese emperor (admittedly an extreme case) was visited only by a few select interlocutors; his visage was deemed so sacred that no others could gaze upon it. Where kings were seen, they were generally approached from a distance and with elaborate protocols intended to reinforce a distinction between royalty and commoners. (Exceptions might be made for war and hunting.) The purpose of this distinction-mongering was to remove the monarch from everyday conflicts and jealousies that beset society, and to further ensure that his (occasionally her) special role was respected.

Royal legitimacy rested, third, upon elaborate rituals - coronations, receptions, holidays, parades, dedications, pilgrimages, cremations, and pageants of various sorts - intended to project their personal style of rule across the land (e.g., Elias 1983). In so doing, kings maintained a central position in society. 
Royal legitimacy rested, fourth, upon spiritual authority. Kings might receive special sanction from the clergy and from religious texts, serve as religious leaders, intercede with the gods on behalf of their subjects, or claim the status of a deity themselves. Monarchical authority and spiritual authority were usually closely intertwined (Bendix 1980).

A final element of legitimacy was the monarch's symbolic role as the head of the body (head of state) and of the family, i.e., as father (occasionally mother) of the nation (Bodin 1955; Filmer 1991). It is probably not coincidental that the Germanic word for king evolved from the word for kindred. Monarchs were able to invoke a form of authority that was familiar by virtue of being familial, and biologically imprinted. Just as a father ought to procure "his children's welfare ... so ought a good prince think of his people ... for a King is trewly Parens Patria, the politique father of his people," thought James I (quoted in McDonagh 2015: 993). Subjects were exhorted to follow the king or queen for the same reason that they were expected to obey their own father or mother, their grandparents, and communal leaders. It was natural to do so, and unnatural contrary to natural law and divine law - to resist. Monarchy is a patrimonial (and very occasionally, a matrimonial) form of governent (Weber 1987, vol 2: 1107). Accordingly, monarchs commanded a good deal of popular respect, not to mention awe. When Charles I, the King of England, was executed in 1649 it is said that the crowd was overwhelmed by emotion and fear (Hibbert 1968: 280).

The legitimacy of monarchs thus rested on the authority of blood, the body, of patriarchy, of religion, and of tradition more generally. Likewise, monarchs were recognized as the defender of tradition. This "symbolic" aspect of the argument might seem at odds with an explanatory framework centered on coordination. However, symbolic power is an essential component of the monarch's advantage in solving the coordination problem of politics, for hereditary rulers enjoyed many symbolic props that other contenders for power were at pains to muster. In a world in which communication, and therefore rational deliberation, was difficult, decisions on important matters were usually legitimated through force of tradition. The monarch represented 
that tradition and therefore occupied a central role in society. He was, symbolically speaking, irreplaceable.

\section{Succession}

Rules of hereditary succession limited claims to the throne, generally to one or several individuals with plausible claims to succeed the sitting monarch. Despite incessant arguments over the legitimacy of rival claimants, potential conflicts were limited in scope. Not only were there a small number of claimants but they were generally members of the same family, offering the prospect of reaching consensus before violence broke out and healing breaches thereafter.

Without the principle of hereditary rule societies found it difficult to secure a smooth transition from one ruler to the next. Strong men could gain power after great struggle, but who would succeed them? Any number of individuals could claim to be the strongest, most intelligent, most skilled, most virtuous, or most meritorious (along some other dimension). When it comes to judging the ineffable talents of leadership, claims are highly indeterminate. And where claims are indeterminate, disputes are likely to devolve into violence.

Studies suggest that succession conflicts were less likely to arise in European monarchies that practiced primogeniture or son succession rather than other forms of succession such as partible inheritance or agnatic seniority (e.g., Kokkonen, Sundell 2014). We surmise that the distinction between monarchical and non-monarchical rule was even more consequential. Since succession opens up a polity to violent conflict - both internal and external - and since this conflict has drastic consequences (Acharya, Lee 2019), a method that provides a smooth and orderly transition from one leader to the next enjoys a critical advantage (Burling 1974).

\section{Unity}

The figure of the monarch provided a focal point around which issues of sovereignty could be resolved and unity preserved. Although monarchs often ruled in consultation with others, and 
although their actual power might be constrained, the existence of a single locus of authority meant that it was easier to preserve unity in a fissiparous society.

By contrast, collective forms of government - centered on an assembly, committee, or open forum - were likely to serve as springboards to societal conflict. Aquinas (2012: Kindle Locations 265-66) observes that "group government [polyarchy] most frequently breeds dissension. This dissension runs counter to the good of peace which is the principal social good." Just as one would not appoint multiple captains to guide a ship, one should not appoint multiple leaders to guide a polity, he argued, echoing a common refrain in the pre-modern era. It may seem odd that a single individual, especially one who was manifestly unrepresentative, could unify wildly diverse pre-modern societies. Yet, it was the very diversity of society that made the presence of the monarch necessary, as s/he provided one of the few - and sometimes the only - common point of reference (Krieger 1970: 5-8), and did so without upsetting long-standing ascriptive identities, social ties, and special rights and privileges. Premodern societies were viewed "not as collections of equal individuals but as communities composed of different orders, each of which fulfilled its due function according to custom and right order" (Reynolds 1999: 92). In this context, "monarchy celebrates and reinforces identification with both the narrowest of loyalties - the family - and the broadest of universalist attachments - to a transcendent God. What it avoids - indeed rejects - is an exclusive or singular ethnic, linguistic, or cultural identity" (L. Anderson 2000: 57). Duindam (2016: 23) writes, "Ruling demanded treating all groups equitably but not necessarily equally: ruling clans occupied privileged positions; priests, soldiers, peasants, and merchants could expect to be treated in different ways, as could regions or ethnicities.” In seventeenth-century Spain, for example, the monarch was expected to recognize the unique identities and statuses of each principality that composed the empire. "These kingdoms must be ruled and governed as if the king who holds them all together were king only of each one them" (Solorzano y Pereira 1776; quoted in Ellis 1992: 53). 
Monarchs are the antithesis of the national ideal, which presupposes a uniformity of cultural modes - language, religion, ethnicity - throughout a nation (B. Anderson 1991: 18-19). As such, they were ideally suited to pre-modern states and empires, whose hallmark was diversity, which lacked a common sense of nationality or peoplehood, and which often spanned noncontiguous territories (Burbank, Cooper 2010).

\section{Time-horizons}

A core problem of governance is that of time-horizons, whereby leaders neglect policies that require short-term sacrifices and long-term investments. Monarchy provided a partial solution to this perennial problem by elongating the tenure of the ruler and institutionalizing power in the hands of a ruling house, which aspired to rule in perpetuity.

Rules of hereditary succession usually meant that power was passed to the next generation, or to a younger sibling. Those ascending to the throne might be quite young, and often not yet adult. Once installed on the throne, monarchs were generally expected to rule until their demise or until illness or dotage made them unfit to rule. Monarchs might be deposed, of course, but such unconstitutional interruptions were rare. As a result, monarchs could expect to rule for quite a long time - considerably longer than other sorts of rulers. This matters insofar as leaders with longer terms have elongated time-horizons (Wright 2008).

Equally important, a sitting monarch considers his reign as part of a dynasty, beginning with his children and stretching far into the future. This is implicit in the notion of the king's "two bodies," one of which referred to his physical body and the other of which lived in perpetuity through the crown (Kantorowicz 1957). Some dynasties lasted for centuries and a few for millennia, during which time wealth and power accumulated in the hands of a single family. Ruling was a family business, and the prosperity of the family depended upon preserving riches and investing in the future. This, too, should elongate the time-horizons of rulers. 
Finally, a sitting monarch - along with the monarch's ruling clique - regarded their political community as a kingdom, which would endure even if one ruling family was replaced by another. Here, time-horizons extended as far into the future as a ruler's political imagination might allow.

Thus, although monarchy represented a personalization of power it also, at the same time, institutionalized power through the royal family and through the abstract notion of an everlasting kingdom. Insofar as kings represented a family lineage stretching forward through time, they were conditioned to assume long time-horizons. Monarchs thus resemble "stationary bandits," and as such were more likely to respect private property and to provide public goods than "roving bandits" (Olson 1993: 572). Additionally, because the lineage of the royal family extended into the future this provided for some continuity of rule and the possibility of intertemporal bargaining - with the understanding that the monarch's descendants would respect agreements struck by the current occupant of the throne, establishing credible commitment (Kiser, Barzel 1989: 400). In this respect, royal families may have functioned in much the same fashion as political parties within modern polities, expanding the time-horizons of the present ruler (Magaloni 2008).

\section{Law and Order}

Advantages in legitimacy, succession, unity, and time-horizons culminated in a public good that was in short supply in pre-modern societies - law and order (North, Wallis, Weingast 2009). In an ordered society, there are basic rules of governance that everyone knows and most everyone obeys, and mechanisms of enforcement to punish those who do not. This opens up the possibility of providing more expansive public goods - property rights, infrastructure, education, social provision - all of which depend upon, and to some degree flow from, public order. By contrast, where public order does not exist, or has broken down, a state of anarchy obtains in 
which violence is common, insecurity high, private investment correspondingly low, and public goods entirely absent.

Anarchy is not a theoretical abstraction. "There was one thing that almost all medieval and early modern aristocrats feared more than tyranny; and that was anarchy," writes John Morrill (2004: 295). While we are accustomed to credit autocratic rule with threats of expropriation (North, Weingast 1989), it is important to bear in mind that before the existence of settled government a greater risk of expropriation stemmed from the lack of public order. Monarchy was an eminently rational solution if its principal alternative was anarchy. Indeed, the juxtaposition of monarchy (order) and chaos (anarchy) is a common theme in political texts from many lands and many historical eras (Grossman 2002).

By virtue of solving the coordination problem of government on a large scale monarchy promised a solution to the perennial problem of public order. Note that the king's interest in maintaining sovereignty over the land coincided with the citizen's interest in preserving life and property. The imposition of a "king's peace" meant that brigands, as well as more serious cases of civil conflict, would be suppressed, allowing for a degree of security for property and for trade to flourish throughout the realm (Myers 1982: 136, 140, 187-92). Monarchs played a direct role in establishing the rule of law by dispensing royal charters and establishing royal courts (Nelson 1995: 409). This occurred because of the happy coincidence that by dispensing justice monarchs could extend the writ of their authority, displacing regional powers and sometimes earning extra income (since judgments were often contingent upon payment a fee). Although decisions rendered by the king, or the king's courts, were not always predictable or rulebound, they had the virtue of being decisive and backed by force (Myers 1982: 187). Prior to rule of law there must be rule by law, and monarchs were effective in laying down the law - their law. 


\section{The Demise of Monarchy}

Monarchy's institutional advantage in the pre-modern era stemmed from its capacity to overcome coordination dilemmas in disconnected societies. As societies became more connected in the modern era, this advantage disappeared.

Greater connectivity can be credited to improvements in infrastructure, trade, and schooling, and the increasing density of human settlement. Of these, the factor with greatest political relevance is probably the development of mass communications, allowing leaders to establish a direct connection to their followers by communicating with all of them

simultaneously. The printing press, newspapers, national postal systems, the telegraph, television, and the internet all played their part, in various historical eras (Headrick 2000). Of these, the tool with the most immediate and far-reaching impact may have been the radio, which became widely used in many advanced industrial countries in the 1920s and spread quickly to the developing world, where it remains a dominant channel of information today (Hale 1975; Castro 2013). W. Philips Davison (1965: 136) calls radio "the greatest single instrument for involving people in emerging countries in political activity.”

The effect of mass communication was to overcome the tyranny of distance, assuring that local communities were no longer isolated from each other. Over the past three centuries, a public sphere arose (Habermas 1991), and with it consciousness of a cross-regional "national" identity based on the (presumed) shared characteristics of lay citizens (B. Anderson 1991). Using new communication tools at their disposal, elites developed new systems of rule, all of which bore the imprint of mass politics. Whether democratic or autocratic, representative or plebiscitarian, all contemporary systems of rule featured mass mobilization - via political parties, elections, referenda, public demonstrations, or other vehicles (Huntington 1968). In this respect, they contrasted starkly with the age-old system of hereditary succession, which engaged citizens only as passive spectators and in which there was no (or very little) common identity as a people or nation, except that provided by the over-arching dignity and magnificence of the monarch. 
To be sure, monarchs might appropriate new tools of mass communication for their own purposes (Blain, O'Donnell 2001). However, they could not embrace a mass ideology without compromising the terms of their special place of privilege and power. People could be mobilized to witness coronations and other rituals presided over by a monarch. However, there was little for them to do. They had no role to play, other than to passively observe.

Indeed, mobilizing the masses is at cross-purposes with the raison-d'etre of monarchy to remove masses from politics and depress the mobilization of humanity against the state, i.e., to keep order and maintain a central locus of sovereignty. So embracing modern telecommunications was not in the long-term interests of monarchs. It generally worked to desacralize sitting monarchs, exposing their personal lives - and, inevitably, their foibles - to public scrutiny. Observed up-close and personal, royals were revealed to be human, all too human.

Mass communications also privileged those who could use it to their advantage, which meant cultivating a personal relationship between leader and followers. One can televise a coronation, but it takes a different set of skills to hone a strong media presence. Immediacy, rather than transcendence, is required. And this sort of charisma is unlikely to be transmitted intergenerationally through a royal line.

The core problem for monarchs was that their traditional form of leadership was no longer needed. The effect of increasing connectedness was to mitigate the primordial coordination problem of government, making other forms of political organization practicable on a grand scale for the first time in human history and undermining the principal rationale of monarchy as the only viable alternative to anarchy.

Remaining justifications for monarchy tended to be parochial rather than cosmopolitan. In an age of mass communications, monarchs could no longer claim an exclusive role in knitting together a diverse and far-flung empire. But they could plausibly claim to preserve the unique features and independence of a small and homogeneous people, those who share the monarch's own ethnic, religious, or linguistic identity. Hence, in modern times we find monarchs 
emphasizing their representation of - rather than their differentiation from - society. In this vein, the Prince of Liechstenstein claims to represent the distinctive people of that micro-state (Veenendaal 2014). Instead of universality, monarchs came to symbolize particularity in the modern era.

\section{Concept and Measure}

Despite its ubiquity, monarchy is rarely defined in an explicit fashion. Over the centuries, it has carried a variety of connotations including (a) rule by one (the classical sense, dating back to Aristotle), (b) absolute power, (c) grandeur, (d) hereditary succession, (e) divine right, and (f) aristocracy. It has also been associated with a multitude of formal titles, often centered in a particular region or language, e.g., baron, basileous, caliph, czar, emir, emperor, huangdi, huey tlatoani, kaiser, khagan, khan, king, maharaja, malik, padishah, pasha, pharaoh, prince, raja, Sapa Inka, shah, shahanshah, sultan, tenno, tianzi, and wang.

A useful definition for social-scientific purposes should identify features of a subject that resonate with current usage, that clearly demarcate it from closely related phenomena (in this case, other regime types), that carry a consistent meaning across settings (historical and geographic), and that may potentially shed light on outcomes of interest.

With these goals in mind, we propose that the core idea of monarchy is to monopolize power, money, and status in the hands of a single ("royal") family (Herb 1999). This is achieved through an executive office that is (a) held by a single individual, (b) endowed with life tenure, (c) hereditary, and (d) of non-trivial importance. After reviewing these attributes, we develop a binary index along with several alternative indices. In the final section, we compare these indices to each other and to extant indices produced by other researchers. 


\section{Rule by one}

The office of monarch is usually held by a single individual - the monarch or king. There are just a few exceptions. In Swaziland, power is formally shared by the king and his mother, though the latter generally plays a secondary role (Kuper 1986). In many instances, power is temporarily shared between a monarch who is not yet of age or otherwise impaired and a regent, generally a family member. Nonetheless, the office remains under control of the royal family, which is what qualifies it as a monarchy according to our interpretation.

\section{Life tenure}

Once crowned, a monarch enjoys life tenure. There are no term limits and no formal means to remove a sitting monarch except in circumstances of extreme malfeasance or incapacity. Of course, many monarchs have abdicated, been deposed, or overthrown, and in some polities these were frequent events. This might signal a flawed monarchy. But it is still a monarchy, according to our definition, so long as methods of removal are not institutionalized. A monarch must have the constitutional right to hold on to the crown unto death.

\section{Heredity}

Under normal circumstances only members of the royal family are eligible to assume the position of monarch. Royalty means descent from a previous ruler, typically the founder of a dynasty. Granted, rules for defining membership in the royal family could be mesmerizingly complex, as they were for Japan (Webb 1968: 78-80). Sometimes, the (extended) royal family is large and many individuals can therefore mount a plausible claim to the throne, as in Saudi Arabia (Herb 1999). Nonetheless, family defines the universe of eligible rulers and the closer one is to the current ruler or the founder (by some recognized principle of descent), the better one's claim to the throne. By contrast, where no royal family is able to monopolize power we regard the system as non-monarchical - even if the ruler assumes the title of king (e.g., Poland during the pre- 
modern era) or emperor (e.g., the Roman Empire, where rule was only occasionally passed down within a family).

Temporary violations of hereditary succession may be caused by war, foreign occupation, coup/revolution, lack of a qualified heir, or disagreements among the royal family and other actors about whom should succeed to the throne. If the interregnum is short, and the polity reverts to hereditary rule, we shall regard the polity as retaining a monarchical form. For example, if one ruling family loses power and another assumes office in its stead, establishing a new royal line, the regime type is constant despite a change of personnel. What matters is that family status is regarded as an essential criterion for holding executive office.

Granted, the point at which power becomes hereditary - i.e., when the family status of would-be occupants of executive office comes to overshadow other characteristics - is often difficult to ascertain (Lachaud, Penman 2008). As in many European polities, the French monarchy evolved from a system of election in which a variety of contestants - not necessarily related to the current ruler - could compete. France's first dynasty ruled from 987 to 1328 , but the Capetians "never made a specific claim to a hereditary right to the throne" (Fawtier 1960: 49). Yet, because there was no real opposition to the successors nominated by the Capetian family we classify the system as monarchical. Over time, the hereditary principle became firmly established such that it was virtually inconceivable that anyone other than a member of the royal family could qualify for the job. A similar pattern may be establishing itself in North Korea today; until it is, we shall regard North Korea as a republic.

Operationally speaking, we code a system as hereditary if the practice is enshrined in law, if it is avowed by a sitting ruler (who proclaims his or her intention to restrict succession to family members), or if it is so well-established that it may be regarded as a norm (as evidenced by family trees showing relationships among successive rulers). Either de jure principles or de facto practices are sufficient to qualify a system as hereditary. Only where both are absent is a system classified as republican. 
Hereditary practices of succession vary considerably across monarchical systems and even within the same polity. Preference for the first-born, or primogeniture, may be understood as (a) absolute/equal/lineal (whether male or female), (b) agnatic/patrilineal (first-born male or female through the male line), (c) uterine (first-born male through the female line, e.g., the son of the sister of the previous monarch), (d) male-preference (females accorded the throne only if no males available), (e) Salic (females excluded altogether), (f) porphyrogeniture (preference to the first male born 'in purple,' i.e., after his father ascended to the throne), or (g) matrilineal (femalepreference). Other practices include ultimogeniture (precedence to youngest son), agnatic seniority (where brothers precede sons), partible inheritance (division of the realm among offspring), designation (where the sitting monarch designates a successor - sometimes crowned prior to the death of the sitting monarch), election or acclamation (generally by a group of unelected elites), or contest (generally among sons of the sitting monarch) (Duindam 2016: ch 2).

One might regard primogeniture, ultimogeniture, agnatic seniority, and designation as the purest versions of monarchy since they privilege and preserve the family unit. However, it is important to bear in mind that these principles of selection were not always clearly defined or strictly adhered to, and often intermingled. For example, preference might be given to the monarch's first-born except in instances when that individual was not regarded as suitable - a matter of opinion, evidently, and one that might be determined in the final instance by the sitting monarch or by a college of electors.

Hereditary succession by election may seem like a contradiction in terms; yet, this method was widely used in Europe in the Middle Ages and persisted in the Holy Roman Empire. We regard a system as hereditary if candidates were limited to those with royal blood. Note also that elections were unlikely to constitute a level playing field, and might serve merely to validate choices already made by a sitting monarch or high-ranking family members. Accordingly, Wolf (1991: 193, 253) does not regard election as qualitatively different from other succession rules employed in Europe. 
It is sometimes difficult to say which precise method of selection was the law of the land in a given polity at a given point in time (Duindam 2016: ch 2). Even where rules of descent were clear, controversy was bound to erupt in situations when no immediate descendants of the ruling monarch were available and when different rules came into conflict with one another (Wolf 1991). However, it is usually clear when a system of system of leadership selection is limited to members of a royal family, which is what qualifies it as hereditary in our schema.

\section{Power}

An executive must serve a non-trivial function in order to qualify as a monarch. S/he might make all key decisions himself, with little consultation and few constraints on the exercise of power an "absolutist" form of rule. S/he might appoint policymakers who are accountable (at least to some degree) to him or her, as in Jordan and Monaco today, or the Ottoman Empire previously.

By contrast, where a hereditary executive has no share in policymaking and is displaced by a fully democratic body we surmise that the king neither reigns nor rules; popular sovereignty has supplanted monarchic sovereignty (Huntington 1966: 763-64). Accordingly, we do not regard present-day United Kingdom or Sweden as monarchical regime types.

Granted, it is sometimes difficult to pinpoint the precise moment in time when an elective body eclipses a monarch, rendering the latter superfluous. Nonetheless, it is critical to distinguish hereditary executives who matter from those whose position is purely vestigial. In coding, we have tried to discern whether the monarch exercises more political influence than any other actor in the polity. If so, we categorize the state as monarchical (e.g., contemporary Tonga); if not - if non-hereditary rulers overshadow the hereditary ruler - it is coded as republican.

\section{Coding}

Regime types are identified as monarchical if they satisfy the four conditions laid out above - rule by one, life tenure, heredity, and power. Information required to make these judgments is drawn 
from a diverse set of historical sources including general histories, Wikipedia entries, and general works on monarchy.

States within Europe are coded from 1100 to 1700 at centennial intervals. We adopt a "Braudellian" definition of Europe including territories at the periphery, i.e., parts of west Asia in the East, Anatolia in the Southeast, and North Africa in the South. After 1700, all states throughout the world are coded annually. Historical polities and their GIS polygons are drawn from a variety of datasets, as indicated in Table 1.

Table 1: Sources for Polities and Polygons

\begin{tabular}{llll}
\hline \hline Source & Period & Region & Data \\
\hline Coppedge et al. 2017 & $1789-$ & World & Polities \\
Gleditsch, Ward 1998 & $1800-$ & World & Polities \\
Gerring, Wig, Tollefsen, Apfeld 2018 & $1789-$ & World & Polygons \\
EuroAtlas (Nussli 2017) & $1100-1800$ & Europe & Polities and polygons \\
GeaCron (geacron.com/the-geacron-project/) & $1700-1900$ & World & Polities and polygons \\
\hline \hline
\end{tabular}

The resulting index may be compared with extant indices of monarchy, as shown in Table 2. It will be seen that extant indices offer broad coverage in the contemporary period but none extend prior to 1789, omitting the golden age of monarchy. Importantly, codings across these indices are highly correlated. Despite small variations in coding rules there appears to be fairly strong consensus about which polities qualify as monarchical in the contemporary era, offering comfort to those who might worry about a lack of consensus around this complex concept. 
Table 2: Monarchy Indices

\begin{tabular}{lcccc}
\hline \hline & States & Years & Obs & Pearson's r \\
\hline Authors & 681 & $1100-2005$ & 24,308 & - \\
Wahman, Teorell, Hadenius (2013) & 189 & $1972-2010$ & 6,587 & 0.9325 \\
Cheibub, Gandhi, Vreeland (2010) & 194 & $1946-2008$ & 8,858 & 0.8285 \\
Geddes, Wright, Frantz (2014) & 152 & $1946-2010$ & 7,891 & 0.8953 \\
Anckar, Fredriksson (2016) & 194 & $1800-2015$ & 17,531 & 0.9579 \\
Teorell, Lindberg (2015) & 173 & $1789-2016$ & 16,562 & 0.7674 \\
\hline \hline
\end{tabular}

Note: Where datasets provide alternate operationalizations of monarchy we record values for the coding scheme that is closest to our own conceptualization. Observations are annual except for the authors' monarchy index, which is centennial from 1100 to 1700 and annual thereafter.

\section{Scope-conditions}

Our dataset, along with other datasets noted in Table 2, are limited to polities with a state-like form of government. States are understood as political units with a single locus of power (although perhaps not a fixed capital), some degree of sovereignty (sufficient to allow a choice of governmental forms), a recognized territory which the government controls (although frontiers may be only loosely delimited and controlled), and a governmental apparatus that persists from one ruler to the next (perhaps with some changes of a patrimonial nature). This is a fairly standard definition of the subject as it pertains to the pre-modern era and is consistent with the way in which states are identified by our sources (discussed above).

The justification for focusing on states is both practical and theoretical. From a practical perspective, there is no way we can code political practices in non-state entities prior to the modern era in a comprehensive fashion. Such an exercise would be limited in scope and highly speculative.

From a theoretical perspective, we surmise that a monarchical form of government was likely to develop only in state-like polities. Other political units such as bands, tribes, and chiefdoms were small enough to be governed in an informal fashion and power could be widely diffused without encountering significant coordination problems; there was little justification for monopolizing power in the hands of a single family. Moreover, because small societies are unable 
to support bureaucracies whoever leads the group will need to do much of the work of governing $\mathrm{him} /$ herself, such as leading forces into battle and assuring that food and shelter is available. This puts a premium on merit rather than heredity in the choice of leaders, and since merit is fairly easy to judge and to monitor - being up close and personal - there is a disincentive to appoint the person who happens to be related to the former ruler if there is someone better qualified for the job.

\section{Historical Portrait}

Using the monarchy index described above we are able to map the rise and fall of this distinctive regime type in Europe at 100-year intervals from 1100-2000, as shown in figures posted in Appendix B. These snapshots confirm that monarchies were the dominant regime-type in this region of the world through 1800. Republics were largely limited to areas along the Baltic Sea (1400), the Italian peninsula (1400-1800), the Alpine region (1500-), the Low Countries (1600-), the Grecian archipelago (1700), France (1800-), and parts of North Africa (1800). Most of the territory of Europe, and most of its state-like entities, were monarchical. After the French Revolution, the tide turned against monarchy in Europe, leaving only a few micro-states (e.g., Liechstenstein) on the continent and a few on the North African periphery (e.g., Morocco) at the turn of the twenty-first century.

A corresponding set of maps in Appendix $\mathrm{C}$ show the location of monarchies around the world at centennial intervals from 1700 to 2000 . Here, the fate of monarchies in Europe is replicated, with important regional differences. Relative to Europe, monarchies died more quickly in the New World and lasted longer in Asia. In any case, by 2000 they were all but extinguished in every region except the Middle East.

Figure 1 displays the number of states that were monarchies and republics in Europe from 1100 to the present. In the High Middle Ages, there were roughly sixty states that could be characterized as monarchical, and only a handful that were not. The number of monarchies grows 
over the next two centuries, largely as a product of the increasing number of states in Europe. Monarchies begin to decline in the fifteenth century, and in the sixteenth century the number of republican states begins to grow, narrowing the gap between these regime types. In the eighteenth century, monarchy undergoes a steep decline, which is partially a product of the consolidation of states in Europe (the number of republics also declines, though only modestly). Monarchy recovers briefly after the passing of the Napoleonic era, and then experiences a final decline in the late nineteenth and early twentieth century. By 1920 there are only a handful of monarchies left in Europe.

Globally, the number of monarchies and republics is tracked over the past three centuries in Figure 2. Here, the patterns are easier to follow. The number of monarchies remains fairly constant in the nineteenth century until 1870, at which point monarchies enter a long, slow decline. By contrast, republics are fairly stable in number through the nineteenth century but undergo a dramatic increase in the twentieth century. The tipping point is in 1910, at which point republics out-number monarchies for the first time in recorded history. After 1980, the number of monarchies stabilizes at about sixteen (reduced to thirteen as of today).

An important caveat is that our survey is limited to state-like entities, as described in the previous section. If one were able to include bands, tribes, and chiefdoms - most of which fail to reach our definition of statehood and most of which were probably non-monarchical - the dominance of monarchy would recede as one travels back in time for the simple reason that there were fewer states. 
Figure 1: Monarchies and Republics in Europe, 1100-2005

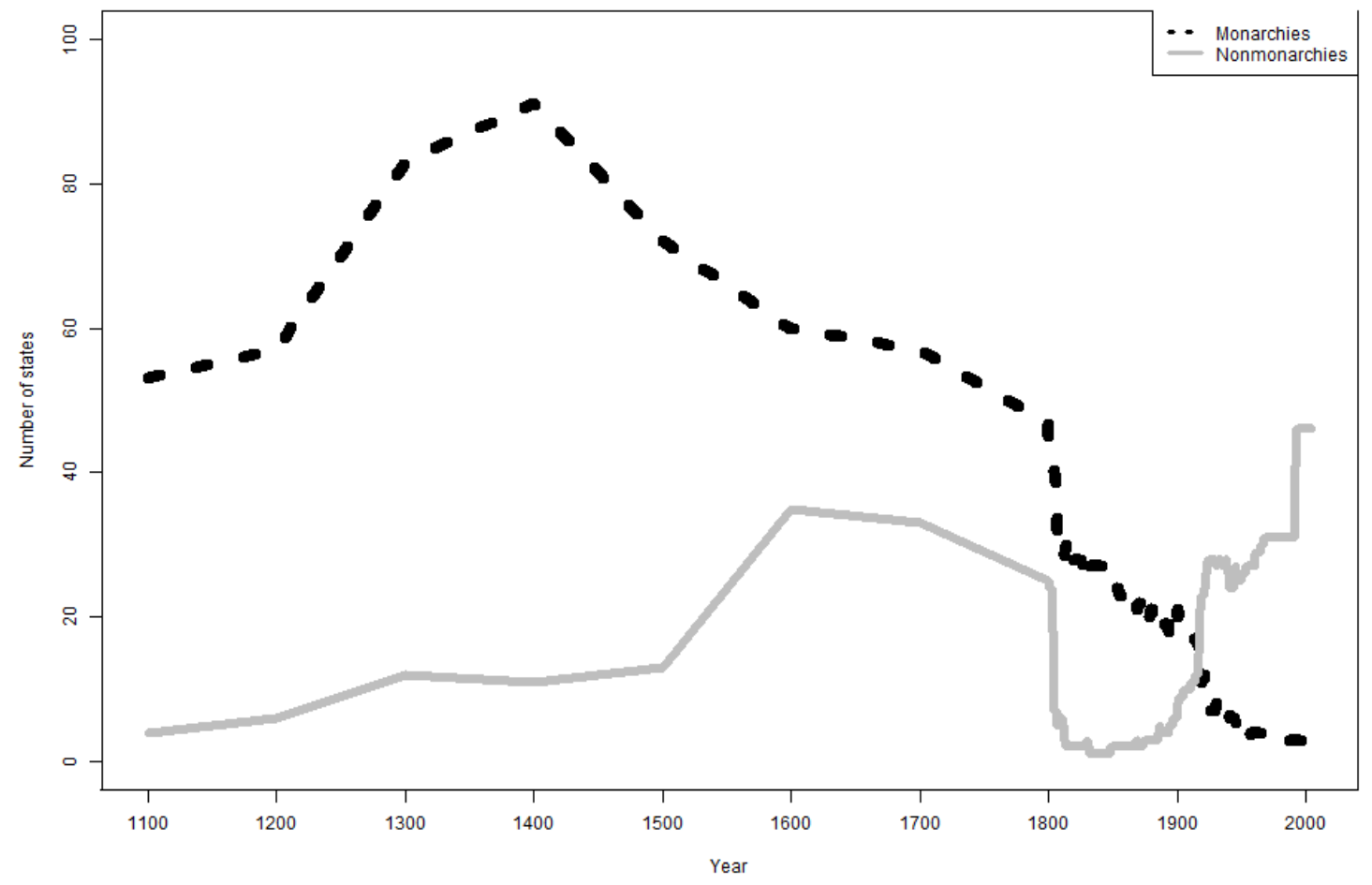

Figure 2: Monarchies and Republics in the World, 1700-2005

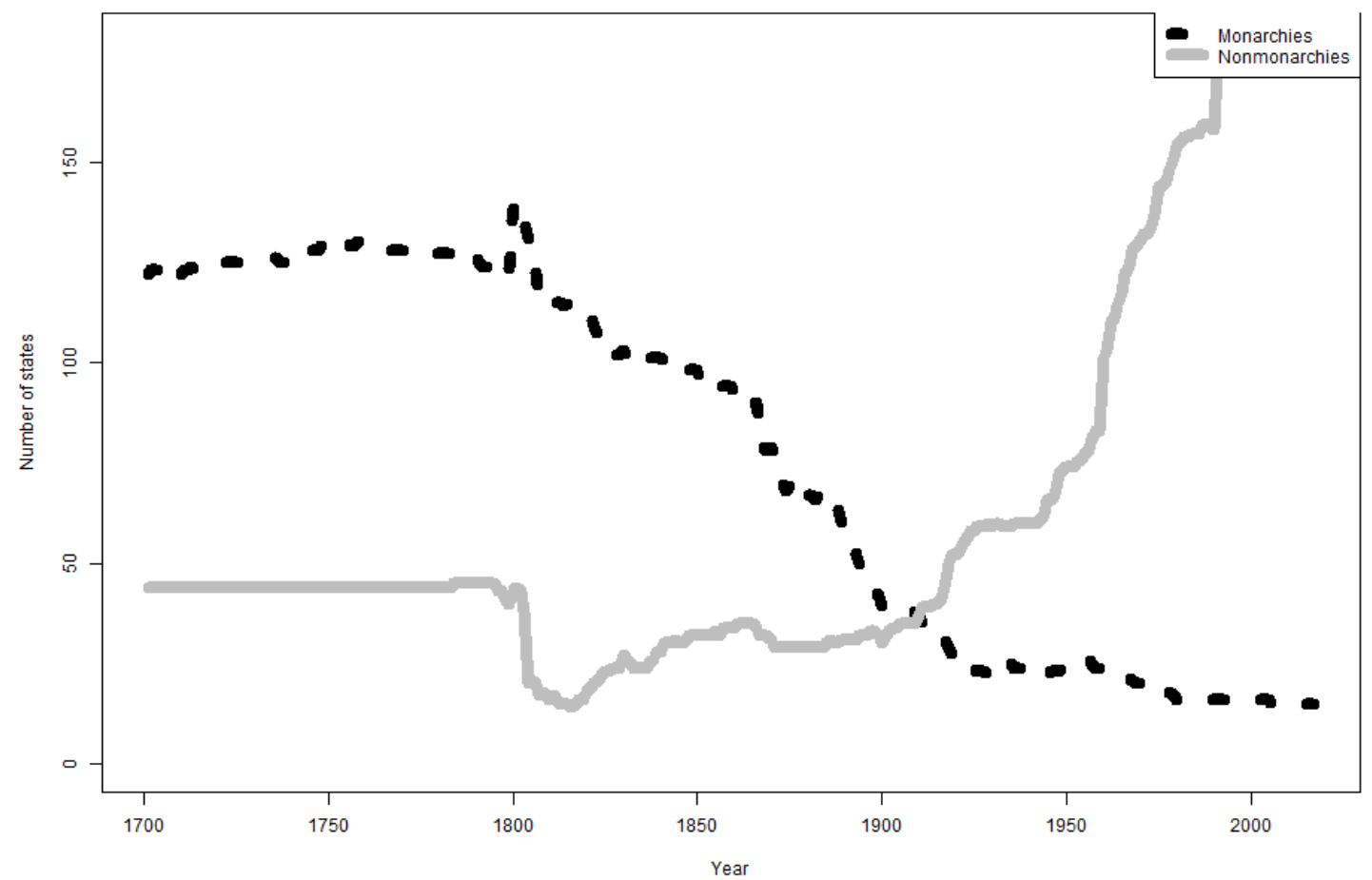




\section{Hypotheses and Analyses}

We have argued that monarchy solved the primordial coordination problem of politics in the premodern era. Where societies are disconnected a focal point is needed and monarchy was, for millennia, a readily available heuristic for establishing legitimate government. In the modern era, as societies became more interconnected, monarchy's advantage disappeared. With societies now highly mobilized and interconnected, monarchy's inability to integrate the masses into politics became a defect rather than an asset.

Although coordination cannot be directly observed, suggestive evidence may be drawn from the histories of states employing varying regime types. Here, we lay out a set of hypotheses that bear on the strength, stability, and institutionalization of regimes - with the expectation that monarchies will be more effective in solving coordination problems than republics in the premodern era and republics will out-perform monarchies in the modern era. A final hypothesis concerns the proximal cause of monarchy's demise in the modern era. Each hypothesis is subjected to a brief empirical test. To conserve space, variable definitions, sources, and descriptive statistics are relegated to Appendix D.

\section{Territory $\left(H_{1}\right)$}

Insofar as a regime type is successful it ought to be capable of organizing power on a grand scale. State size is an especially important test for the theory given that it imposes a direct barrier to coordination, making connections among citizens more difficult. It also serves as a proxy for social diversity (e.g., by language, ethnicity, religion, race, or socioeconomic standing), imposing a second barrier to coordination. As a rule, we expect that larger states are more diverse, an association that is likely to be especially strong in the pre-modern era when social groups were generally smaller and more localized. This leads to our first hypothesis. 
$H_{1}$ : Monarchies control larger territories in the pre-modern era and smaller territories in the modern era.

To test this hypothesis, Figure 3 compares the territorial size of monarchies and republics in Europe (from 1100) and globally (from 1700). To do so, we calculate the average size of monarchies $(M)$ and the average size of republics $(R)$ in Europe and globally in each year of observation. If $M>R$, we record the value of $M / R$. If $M<R$, we record the value of $R / M$ as a negative number. The line at 0 thus represents the point of equality, where the average size of monarchies and republics is the same.

It will be seen that monarchies were many times larger than republics through most of the pre-modern era. From the sixteenth century to the mid-nineteenth century monarchies were from ten to thirty times as large as republics within Europe - with the notable exception of a short period around the time of the French Revolution, when republican rule extended briefly across a wide swath of Europe. Not until World War One did republics surpass monarchies in size, a pattern that persists to this day in Europe. Note that the only remaining European monarchies Liechtenstein and Monaco - are tiny, though the graph shows parity because of the inclusion of Morocco, a large state which is defined as part of Europe. Across the world, the turning point is the early nineteenth century, when the two regime types approached parity, reversing an ageold pattern.

One might also measure the size of states by their population. Such an analysis would yield very similar results, as territory and demography are correlated - especially prior to the twentieth century when populations settlements were more diffuse. 
Figure 3a: Relative Size of Monarchies in Europe, 1100-2005

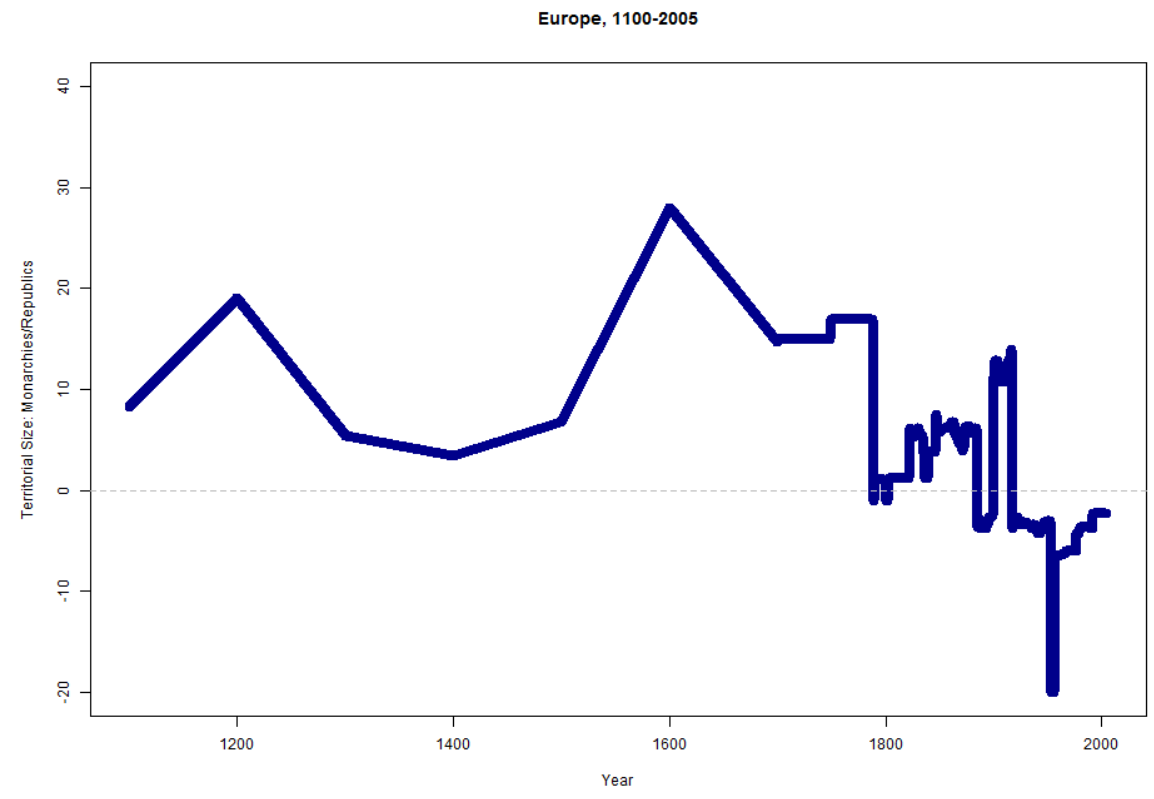

Figure 3b: Relative Size of Monarchies in the world, 1700-2005

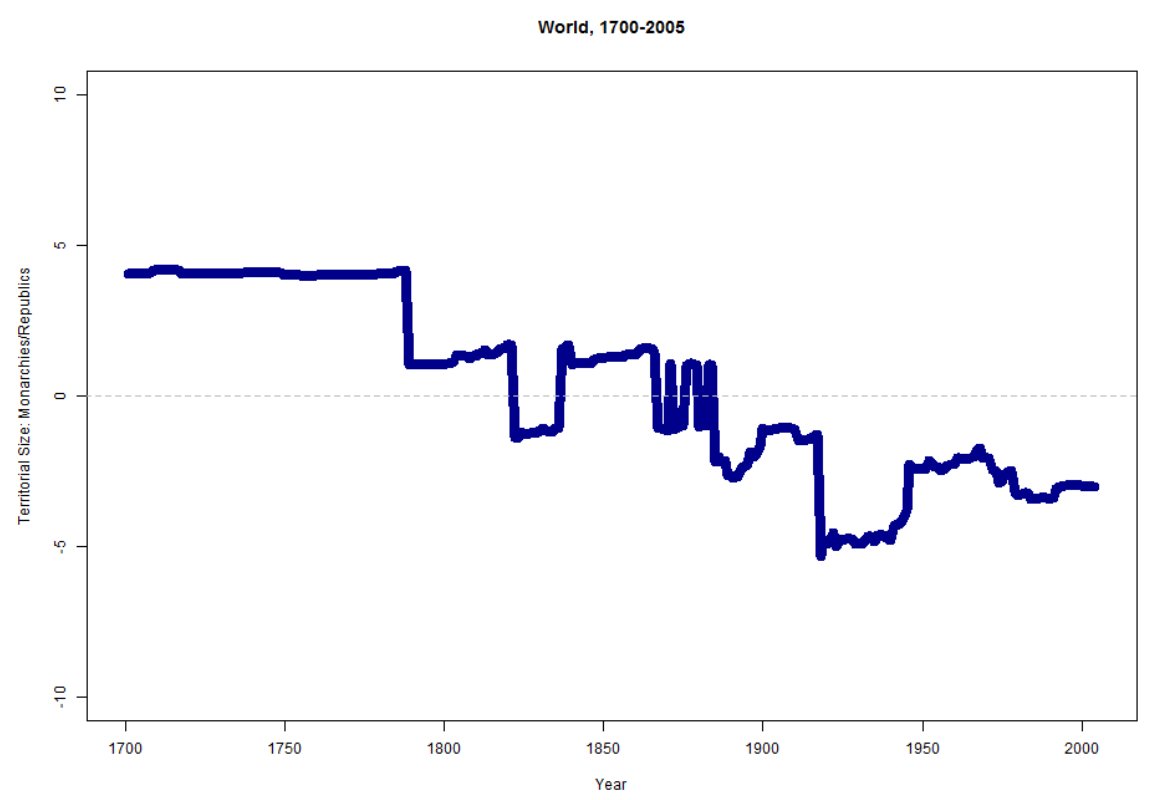




\section{Political stability $\left(H_{2}\right)$}

Insofar as a regime type is successful it ought to pave the way for political stability. This leads to our second hypothesis.

$\mathrm{H}_{2}$ : Monarchical states are more stable in the pre-modern era and less stable in the modern era.

Menaldo (2012) finds evidence for this proposition in a sample centered on the MENA region in the postwar era. To test the proposition in a global sample and across a longer timeperiod we define stability as continuity of constitutional rules pertaining to who sets policies and how these individuals are selected, i.e., regimes, as coded by Djuve, Knutsen \& Wig (2019). For example, a consolidated democratic regime is defined by elections as the mode of selecting principals and (indirectly) policies, so a regime change would occur if there is a substantial departure from this. A personalist dictatorship is characterized by the rule of the dictator, so there is a regime change if this dictator is removed from office through an unscripted process. An authoritarian party regime such as China hinges on the rules by which the ruling party is governed, so any change in those rules is understood as a regime change.

With this definition of regimes (not to be confused with regime-types), we examine the probability of regime breakdown (i.e., change) in Table 3. This binary outcome is analyzed with logistic regression models. The first set of tests focus on the pre-modern era (1800-1920). Model 1 includes a variety of covariates that might serve as confounders such as per capita GDP (log), population (log), democracy and its quadratic (to account for non-linearity in the relationship), and per capita GDP growth. We also include time-trends capturing temporal persistence in regime-duration using duration terms that are linear, squared and cubed, following the standard in the literature (e.g., Carter, Signorino 2010), as well as region and year fixed-effects. Standard errors are clustered by state. Model 2 drops all covariates except per capita GDP, population, and the time-trends. Model 3 returns to the benchmark specification, while restricting the sample to 
regime breakdowns that do not constitute transitions from monarchy to republic. Estimated coefficients for the monarchy variable show that monarchies are less likely to experience regime breakdowns during this early period. We presume that this pattern would be even stronger if we examined a longer historical period.

The second set of tests focus on the contemporary era (1920-2006), where we repeat the same battery of specifications and sample restrictions. In Models 4-6 it will be seen that monarchies are more vulnerable, i.e., more likely to experience a regime breakdown - though the effect attenuates when we remove transitions from monarchy (Model 6). Taken together, these tests suggest that monarchies were less prone to breakdown in the nineteenth century and more prone to breakdown in the twentieth century, corroborating our hypothesis.

Table 3: Regime Breakdown

\begin{tabular}{|c|c|c|c|c|c|c|}
\hline \multirow{2}{*}{$\begin{array}{l}\text { Time period } \\
\text { Sample }\end{array}$} & \multicolumn{3}{|c|}{$1800-1920$} & \multicolumn{3}{|c|}{ 1920-2006 } \\
\hline & All & All & $\begin{array}{l}\text { Monarchy } \\
\text { transitions }\end{array}$ & All & All & $\begin{array}{l}\text { Monarchy } \\
\text { ansitions }\end{array}$ \\
\hline & 1 & 2 & 3 & 4 & 5 & 6 \\
\hline Monarchy & $\begin{array}{c}-0.547^{* *} \\
(-2.14)\end{array}$ & $\begin{array}{c}-0.341 * * \\
(-2.02)\end{array}$ & $\begin{array}{c}-0.770^{* * *} \\
(-2.99)\end{array}$ & $\begin{array}{c}0.430 * * \\
(2.55)\end{array}$ & $\begin{array}{c}0.290 * * \\
(2.05)\end{array}$ & $\begin{array}{l}0.176 \\
(0.87)\end{array}$ \\
\hline GDPpc (log) & $\begin{array}{c}-0.339 * * \\
(-1.96)\end{array}$ & $\begin{array}{c}-0.255^{* * *} \\
(-2.78)\end{array}$ & $\begin{array}{c}-0.364 * * \\
(-2.09)\end{array}$ & $\begin{array}{c}-0.277 * * * \\
(-4.02)\end{array}$ & $\begin{array}{c}-0.339 * * * \\
(-7.04)\end{array}$ & $\begin{array}{c}-0.266 * * * \\
(-3.84)\end{array}$ \\
\hline Population (log) & $\begin{array}{c}-0.161 * * \\
(-2.33)\end{array}$ & $\begin{array}{c}0.067 * * * \\
(3.37)\end{array}$ & $\begin{array}{c}-0.171^{* *} \\
(-2.24)\end{array}$ & $\begin{array}{l}0.002 \\
(0.09)\end{array}$ & $\begin{array}{l}0.011 \\
(0.66)\end{array}$ & $\begin{array}{l}0.000 \\
(0.01)\end{array}$ \\
\hline Democracy & $\begin{array}{l}2.796 \\
(1.60)\end{array}$ & & $\begin{array}{l}2.626 \\
(1.48)\end{array}$ & $\begin{array}{c}7.346^{* * *} \\
(6.47)\end{array}$ & & $\begin{array}{c}6.852^{* * *} \\
(5.98)\end{array}$ \\
\hline Democracy $^{2}$ & $\begin{array}{c}-8.594 * * * \\
(-3.17)\end{array}$ & & $\begin{array}{c}-8.203^{* * * *} \\
(-2.99)\end{array}$ & $\begin{array}{c}-10.973^{* * *} \\
(-7.47)\end{array}$ & & $\begin{array}{c}-10.270^{* * *} \\
(-7.12)\end{array}$ \\
\hline GDPpc growth & $\begin{array}{c}-0.039 * * \\
(-2.28)\end{array}$ & & $\begin{array}{c}-0.038^{* *} \\
(-2.11)\end{array}$ & $\begin{array}{c}-0.025^{* * *} \\
(-4.49)\end{array}$ & & $\begin{array}{c}-0.025^{* * *} \\
(-4.40)\end{array}$ \\
\hline Region dummies & $\checkmark$ & & $\checkmark$ & $\checkmark$ & & $\checkmark$ \\
\hline Year dummies & $\checkmark$ & & $\checkmark$ & $\checkmark$ & & $\checkmark$ \\
\hline Duration1 & $\begin{array}{c}-0.039 * * * \\
(-3.02)\end{array}$ & $\begin{array}{c}-0.048^{* * *} \\
(-3.81)\end{array}$ & $\begin{array}{c}-0.042^{* * *} \\
(-2.96)\end{array}$ & $\begin{array}{c}-0.074^{* * *} \\
(-7.18)\end{array}$ & $\begin{array}{c}-0.069^{* * *} \\
(-7.07)\end{array}$ & $\begin{array}{c}-0.077 * * * \\
(-7.44)\end{array}$ \\
\hline Duration2 & $\begin{array}{c}0.001 * * \\
(2.52)\end{array}$ & $\begin{array}{c}0.000^{* *} \\
(2.33)\end{array}$ & $\begin{array}{c}0.001^{* *} \\
(2.44)\end{array}$ & $\begin{array}{c}0.001 * * * \\
(5.32)\end{array}$ & $\begin{array}{c}0.001 \text { *** } \\
(3.90)\end{array}$ & $\begin{array}{c}0.001 * * * \\
(5.49)\end{array}$ \\
\hline Duration3 & $\begin{array}{c}-0.000^{* *} \\
(-2.37)\end{array}$ & $\begin{array}{c}-0.000^{*} \\
(-1.85)\end{array}$ & $\begin{array}{c}-0.000^{* *} \\
(-2.30)\end{array}$ & $\begin{array}{c}-0.000 * * * \\
(-4.35)\end{array}$ & $\begin{array}{c}-0.000 * * * \\
(-2.99)\end{array}$ & $\begin{array}{c}-0.000 * * * \\
(-4.45)\end{array}$ \\
\hline $\begin{array}{l}N \\
\text { Log likelihood }\end{array}$ & $\begin{array}{c}2803 \\
-779.810\end{array}$ & $\begin{array}{c}3748 \\
-1093.807\end{array}$ & $\begin{array}{c}2776 \\
-751.047\end{array}$ & $\begin{array}{c}8913 \\
-1960.126\end{array}$ & $\begin{array}{c}9767 \\
-2267.092\end{array}$ & $\begin{array}{c}8872 \\
-1912.058\end{array}$ \\
\hline
\end{tabular}

Outcome: $1=$ breakdown, $0=$ no breakdown. Model: logistic regression, t statistics in parentheses. $* * * p<0.01, * * p<$ $0.05, * p<0.10$ Constant not reported. Results are robust to random intercept specifications. 


\section{Tenure in office $\left(H_{3}\right)$}

An advantage of monarchy, according to our theory, is that monarchs are apt to have longer time-horizons than other sorts of leaders - at least during the pre-modern era. While timehorizons are unobservable we can observe the length of tenure enjoyed by leaders, which may be regarded as a proxy for their time-horizons. (If a leader can expect to enjoy a long tenure in office s/he may be more inclined to make long-term investments.)

Importantly, actual tenure in office is not simply a function of how an office is defined. A monarch's tenure might be cut short by death (a likely occurrence if monarchs accede to the thrown in their dotage), by abdication, or by forceful removal. Consequently, the actual tenure in office enjoyed by monarchs is also a proxy for the legitimacy of that office. Illegitimate rulers are presumably more liable to removal.

Accordingly, we hypothesize:

$H_{3:}$ Monarchs enjoy longer tenure in office than other executives in all periods.

We test this hypothesis with data from the Historical Varieties of Democracy project (Knutsen et al. 2019), which provides information on 3,937 heads of state and 2,874 heads of government, as well as 196 leaders who served simultaneously in both roles. A head of state (HOS) is an individual or collective body that serves as the chief public representative of a polity. A head of government (HOG) is the chief officer(s) of the executive branch of government, typically presiding over a cabinet. In some states these roles are combined while in most they are separated. After excluding leaders who reigned for less than 100 days, this dataset provides exact dates of appointment and dismissal for 6,933 leaders in 174 states from 1789 to the present.

Across the entire sample, excluding those currently holding power (whose tenure in office is unknown), average tenure among monarchs is nearly sixteen years while average tenure among 
non-monarchs is nearly five years. Monarchs, on average, serve three times as long as other heads of state and heads of government.

To analyze these relationships in a multivariate fashion, we present a series of Cox proportional hazards models in Table 4 where tenure in office serves as the dependent variable. The first model pools all executives and includes only a Monarchy dummy. In the second model, we also include a dummy indicating whether the leader was head of state (HOS) or head of state and government $(\mathrm{HOS} \& \mathrm{HOG})(=1)$ or only head of government $(\mathrm{HOG})(=0)$, a measure of the relative power of the HOS over appointment and dismissal of cabinet ministers, as well as three auxiliary regime characteristics: freedom of association, extension of the suffrage, the quality of elections, and state control over territory (a Weberian measure of stateness).

The third and fourth models retain these controls and instead vary the sample. Since a majority of all monarchs are heads of state, we first drop all heads of government from the sample (model 3). In the final model, we only retain the executives who exercised some influence over the appointment and dismissal of cabinet ministers (model 4).

The evidence across all these models suggests that monarchs endure much longer in office than non-monarchs. This is true for the entire sample as well as for sub-samples focused on different kinds of executives. 
Table 4: Leader tenure, 1789-2016

\begin{tabular}{lcccc}
\hline Sample & All executives & All executives & Heads of state & Influential executives \\
Model & $\mathbf{1}$ & $\mathbf{2}$ & $\mathbf{3}$ & $\mathbf{4}$ \\
\hline Monarchy & $0.369^{* * *}$ & $0.372^{* * *}$ & $0.326^{* * *}$ & $0.317^{* * *}$ \\
& $(0.014)$ & $(0.019)$ & $(0.019)$ & $(0.019)$ \\
HOS or HOS\&HOG & & $0.737^{* * *}$ & & \\
& & $(0.024)$ & $1.126^{* *}$ & $1.310^{* * *}$ \\
HOS vs. HOG power & 1.059 & $(0.064)$ & $(0.108)$ \\
& & $(0.038)$ & 1.134 & $0.693^{* * *}$ \\
Freedom of association & $1.212^{* *}$ & $(0.109)$ & $(0.038)$ \\
& & $(0.093)$ & $0.599^{* * *}$ & 0.982 \\
Suffrage & & $0.777^{* * *}$ & $(0.039)$ & $(0.070)$ \\
& & $(0.036)$ & 0.903 & $0.997^{* * *}$ \\
Free and fair elections & $0.839^{* * *}$ & $(0.072)$ & $(0.001)$ \\
State control over territory & $(0.053)$ & $0.995^{* * *}$ & 190 \\
& & $0.995^{* * *}$ & $(0.001)$ & 4827 \\
\hline States $(N)$ & $(0.001)$ & 190 & 5279 \\
Subjects $(N)$ & & 190 & 3677 & 19938 \\
Failures $(N)$ & 6312 & 3824 & 18839 \\
Observations $(N)$ & 196 & 7032 & & \\
\hline \hline
\end{tabular}

Cox proportional hazard models with exponentiated coefficients and standard errors in parentheses ${ }^{*} p<0.10,{ }^{* *} p<$ $0.05,{ }^{* * *} p<0.01$ Constant not reported.

\section{Conflict $\left(\boldsymbol{H}_{4}\right)$}

Violent conflict is a signal that politics may not be fully institutionalized, and that existing institutions are not doing their job - or not doing their job very well. We anticipate that monarchies enjoy an advantage in this area over non-monarchies, at least in the pre-modern era. All of the distinctive institutional features of monarchy discussed in Section I may damper the impetus for conflict. A ruler who is legitimate is less susceptible to attack (internal or external) and has less need to prove himself by launching an attack against others. A smooth and instantaneous leadership transition - epitomized in the phrase, "The King is dead; Long live the King" - overcomes what is typically the most vulnerable period for a state. A unified leadership leaves few openings for dissenters who might foment conflict. Longer time-horizons may prompt rulers to think twice before entering hostilities, lest they jeopardize their kingdom and their family's heirloom, the crown. Hence, our fourth hypothesis:

$H_{4}$ : Monarchical states are less prone to conflict in the pre-modern era. 
In the modern era, it might make sense to differentiate internal and external conflict, with the idea that internal conflict is more clearly a failure of institutions. However, in the pre-modern era this distinction rings hollow, especially in Europe. Here, virtually every conflict had an "internal" and "external" component. Foes of the state within the boundaries of the state had allies outside, and foes outside had allies inside, so it is difficult to identify any conflict that was purely domestic. This has something to do with the tangled nest of aristocratic alliances that crisscrossed Europe. And it also stems from the fact that most states were small, and many tiny.

To identify conflicts, we rely on Dincecco and Onorato's (2018) conflict database, drawing on comprehensive sources from military historians and covering major military conflicts fought on land in Europe between the year 1000 and 1799. Our principal dependent variable counts the number of conflicts each state is engaged in across each century from 1100 to 1800 . The outcome varies from zero to 200 (France in the $18^{\text {th }}$ century). To mitigate the extreme right skewness of this variable it is transformed by the natural logarithm. The resulting variable is regressed against our Monarchy dummy variable along with century dummies and selected controls in Table 5. Right side variables are measured at the beginning of each century while the outcome records the number of conflicts occurring in the subsequent one hundred years.

A bivariate regression of conflict against monarchy reveals a positive relationship: monarchies experience more conflicts than republics. However, we have shown that monarchies were also more extensive than republics in the pre-modern era (Figure 3), and it stands to reason that a larger state will be entangled in more conflicts as it has more territory to control and more potential adversaries to combat. We construct a number of measures to control for this background feature. Model 1 includes the length of a state's borders (log), along with a dummy variable indicating whether the state sits at the edge of Europe - in which case its full extent is not measurable by polygons in the EurAtlas dataset. Model 2 adds a variable measuring the number of neighbors (log). Model 3 adds the area of the territory (log). The estimated coefficient for Monarchy is negative, highly significant, and remarkably stable across these specifications. 
In a second set of tests, we dichotomize the outcome, re-coding the variable as 0 if a state is not involved in any conflicts over the course of a century and 1 otherwise. This is a reasonable approach insofar as the descent from peace into war represents a qualitative change, while the addition of more conflicts might be viewed as a marginal deterioration. It also solves the problem of extreme outliers. Instead of repeating each specification in the previous sequence, we show only the minimal and maximal specifications - Models 5 and 6 . Here, too, the coefficient is negative, highly significant, and stable. (Results are robust when replicated with a logit estimator.) In summary, there seems ample empirical support for our conjecture that monarchies were less conflict-prone in the pre-modern era. This contradicts the usual impression offered by mythic and historical accounts of kings who make war as a matter of occupation (Jones 2013). When Tilly (1985) declared that "states make wars and wars make states" he was doubtless thinking of kings as the instigators. And it is true that the great monarchies (England, France, Spain) had considerably more wars to their credit than their smaller republican neighbors. However, we have seen that this is a product of grandeur rather than truculence. Small monarchies were more peaceful than similarly sized republics.

While we do condition on several geographic features that are expected to shape regimes and conflict patterns, we do not claim to have clear evidence for a causal effect of monarchy on conflict risk. For example, we can not decisively rule out selection effects, such as would operate if monarchies are less likely to emerge in war-prone territories. However, we have no strong theoretical reason to suspect such effects, and our coefficients remain quite insensitive to the inclusion of confounders that should correlate with such selection processes. 
Table 5: Conflict

\begin{tabular}{|c|c|c|c|c|c|}
\hline \multirow{2}{*}{$\begin{array}{l}\text { Conflict measure } \\
\text { Model }\end{array}$} & \multicolumn{3}{|c|}{ Cumulative (log) } & \multicolumn{2}{|c|}{ Binary } \\
\hline & 1 & 2 & 3 & 5 & 6 \\
\hline Monarchy & $\begin{array}{c}-0.259 * * \\
(0.104)\end{array}$ & $\begin{array}{c}-0.259 * * \\
(0.104)\end{array}$ & $\begin{array}{c}-0.246 * * \\
(0.105)\end{array}$ & $\begin{array}{c}-0.111 * * * \\
(0.033)\end{array}$ & $\begin{array}{c}-0.101^{* * *} \\
(0.035)\end{array}$ \\
\hline Border length (ln) & $\begin{array}{c}0.291 * * * \\
(0.036)\end{array}$ & $\begin{array}{c}0.239 * * * \\
(0.040)\end{array}$ & $\begin{array}{c}0.289 * * * \\
(0.090)\end{array}$ & $\begin{array}{c}0.110^{* * * *} \\
(0.011)\end{array}$ & $\begin{array}{c}0.121 * * * \\
(0.029)\end{array}$ \\
\hline Edge & $\begin{array}{l}-0.166 \\
(0.254)\end{array}$ & $\begin{array}{l}-0.045 \\
(0.251)\end{array}$ & $\begin{array}{l}-0.021 \\
(0.254)\end{array}$ & $\begin{array}{c}-0.174^{* * *} \\
(0.060)\end{array}$ & $\begin{array}{c}-0.129 * * \\
(0.061)\end{array}$ \\
\hline Neighbors (ln) & & $\begin{array}{c}0.184 * * * \\
(0.057)\end{array}$ & $\begin{array}{c}0.176^{* * *} \\
(0.058)\end{array}$ & & $\begin{array}{c}0.061 * * * \\
(0.020)\end{array}$ \\
\hline Area $(\ln )$ & & & $\begin{array}{l}-0.034 \\
(0.048)\end{array}$ & & $\begin{array}{l}-0.019 \\
(0.017)\end{array}$ \\
\hline Century dummies & $\checkmark$ & $\checkmark$ & $\checkmark$ & $\checkmark$ & $\checkmark$ \\
\hline States $(N)$ & 344 & 344 & 341 & 344 & 340 \\
\hline Centuries (N) & 8 & 8 & 8 & 8 & 8 \\
\hline Observations (N) & 654 & 654 & 650 & 654 & 649 \\
\hline$R$-squared & 0.328 & 0.345 & 0.335 & 0.279 & 0.312 \\
\hline
\end{tabular}

Units of analysis: state-century. Ordinary least squares, standard errors clustered by state in parentheses. *** $p<0.01, * * p<0.05, * p<0.10$ Constant not reported.

\section{Mass communications $\left(H_{5}\right)$}

If monarchies were initially successful because they solved coordination problems in situations where coordination among citizens was extremely difficult, their demise should be tied to the decline of this comparative advantage. Specifically, we surmise that monarchies face extinction as tools of mass communication - especially radios - spread.

$H_{5}$ : The diffusion of radios is associated with the decline of monarchy in the modern era.

To test this proposition, we regress our binary index of monarchy against a measure of radio diffusion, the number of radios extant in a state (log).

Table 6 displays the results from a variety of estimators and specifications. The first set of tests employ a pooled ordinary least squares estimator with standard errors clustered by state (to account for serial correlation) and year fixed effects (to account for unobserved variation through time). Right-side variables are lagged fifteen years behind the outcome to mitigate problems of endogeneity. 
Model 1 includes only regional dummies (Eastern Europe/Central Asia, Latin America, MENA, et al.). Model 2 adds a control for democracy, measured in a binary fashion. This is an important confounder since many transitions from monarchy to non-monarchy coincided with a transition to democracy. Model 3 adds a vector of dummy variables measuring different types of authoritarian regimes - party, military, personalist. These are not retained in subsequent specifications because of the loss of sample size, and also because they are collinear with the outcome (personalist regimes, in particular, are very close in conception and measurement to our monarchy variable).

Model 4 adds covariates measuring population (log), natural resource wealth, per capita GDP (log), English colonial heritage, share of population of Muslim heritage, and share of population of Protestant heritage. Model 5 omits states that found themselves on the losing side of World War One, or were significantly weakened by the war, i.e., Russia, Germany, Ottoman empire/Turkey, Austria/Austria-Hungary, Bosnia and Herzegovina, Bulgaria, Croatia, Montenegro, Romania, Serbia and Montenegro/Yugoslavia, and Hungary. Model 6 approaches the binary outcome with a logistic regression model, while maintaining the benchmark specification.

The final set of models apply state fixed effects with a lagged dependent variable. Model 7 is a minimal specification. Model 8 adds population and democracy. Model 9 adds resource wealth and per capita GDP, and thus includes a large set of (measurable) non-static covariates that might serve as confounders.

Across these various tests radios maintains a negative relationship to monarchy. As radios diffuse (in a logarithmic fashion) throughout a population, the probability of having a monarchic regime type declines. Moreover, the coefficient is remarkably stable, despite alterations of specification and estimator. It is notable that cross-sectionally dominated panels as well as temporally-dominated panels behave very similarly. Thus, although the possibility of omitted variables lurks, as it does in all observational research, we regard this as providing fairly strong 
evidence for the proposition that monarchy's demise was related to the rise of mass

communications and the direct, unmediated relationship that it created between leaders and masses, overcoming longstanding coordination problems that had plagued governance in earlier times.

Table 6: Radios and Regime Types

\begin{tabular}{|c|c|c|c|c|c|c|c|c|c|}
\hline \multirow{2}{*}{$\begin{array}{l}\text { Model } \\
\text { Sample }\end{array}$} & \multicolumn{5}{|c|}{ Pooled Linear } & \multirow{2}{*}{$\begin{array}{l}\text { Logit } \\
\text { Full }\end{array}$} & \multicolumn{3}{|c|}{ State fixed effects } \\
\hline & Full & Full & Full & Full & Reduced & & Full & Full & Full \\
\hline Model & 1 & 2 & 3 & 4 & 5 & 6 & 7 & 8 & 9 \\
\hline Radios (ln) & $\begin{array}{c}-0.024 * * * \\
(0.008)\end{array}$ & $\begin{array}{c}-0.023 * * * \\
(0.007)\end{array}$ & $\begin{array}{c}-0.017 * * \\
(0.007)\end{array}$ & $\begin{array}{c}-0.032 * * \\
(0.014)\end{array}$ & $\begin{array}{c}-0.036^{* *} \\
(0.014)\end{array}$ & $\begin{array}{c}-0.454^{* *} \\
(0.200)\end{array}$ & $\begin{array}{c}-0.025^{* *} \\
(0.010)\end{array}$ & $\begin{array}{c}-0.025^{* *} \\
(0.011)\end{array}$ & $\begin{array}{c}-0.024 * * \\
(0.012)\end{array}$ \\
\hline $\begin{array}{l}\text { Democracy } \\
\text { (binary) }\end{array}$ & & $\begin{array}{l}-0.035 \\
(0.027)\end{array}$ & $\begin{array}{c}-0.240^{* * * *} \\
(0.064)\end{array}$ & $\begin{array}{l}-0.056^{*} \\
(0.030)\end{array}$ & $\begin{array}{l}-0.049 \\
(0.032)\end{array}$ & $\begin{array}{c}-1.964 * * * \\
(0.672)\end{array}$ & & $\begin{array}{c}0.007 \\
(0.016)\end{array}$ & $\begin{array}{l}-0.002 \\
(0.015)\end{array}$ \\
\hline Population (ln) & & & & $\begin{array}{c}0.010 \\
(0.019)\end{array}$ & $\begin{array}{c}0.016 \\
(0.020)\end{array}$ & $\begin{array}{c}0.268 \\
(0.259)\end{array}$ & & $\begin{array}{c}0.001 \\
(0.034)\end{array}$ & $\begin{array}{c}0.010 \\
(0.029)\end{array}$ \\
\hline $\begin{array}{l}\text { Natural resources } \\
\text { per cap }\end{array}$ & & & & $\begin{array}{c}0.000 * * * \\
(0.000)\end{array}$ & $\begin{array}{c}0.000^{* * *} \\
(0.000)\end{array}$ & $\begin{array}{c}0.000 \\
(0.000)\end{array}$ & & & $\begin{array}{l}0.000 \\
(0.000)\end{array}$ \\
\hline GDP per cap (ln) & & & & $\begin{array}{c}0.032 \\
(0.024)\end{array}$ & $\begin{array}{c}0.034 \\
(0.024)\end{array}$ & $\begin{array}{c}0.698^{* *} \\
(0.312)\end{array}$ & & & $\begin{array}{l}-0.005 \\
(0.019)\end{array}$ \\
\hline $\begin{array}{l}\text { English colonial } \\
\text { heritage }\end{array}$ & & & & $\begin{array}{l}0.098^{*} \\
(0.055)\end{array}$ & $\begin{array}{l}0.096^{*} \\
(0.056)\end{array}$ & $\begin{array}{c}2.328^{* * *} \\
(0.786)\end{array}$ & & & \\
\hline Muslim & & & & $\begin{array}{l}-0.000 \\
(0.001)\end{array}$ & $\begin{array}{l}-0.000 \\
(0.001)\end{array}$ & $\begin{array}{c}0.013 \\
(0.010)\end{array}$ & & & \\
\hline Protestant & & & & $\begin{array}{l}-0.001 \\
(0.000)\end{array}$ & $\begin{array}{l}-0.001 \\
(0.001)\end{array}$ & $\begin{array}{l}-0.064^{*} \\
(0.037)\end{array}$ & & & \\
\hline $\begin{array}{l}\text { Party } \\
\quad \text { dictatorship }\end{array}$ & & & $\begin{array}{c}-0.313^{* * *} \\
(0.067)\end{array}$ & & & & & & \\
\hline $\begin{array}{l}\text { Military } \\
\text { dictatorship }\end{array}$ & & & $\begin{array}{c}-0.202^{* *} \\
(0.082)\end{array}$ & & & & & & \\
\hline $\begin{array}{l}\text { Personal } \\
\text { dictatorship }\end{array}$ & & & $\begin{array}{c}-0.303^{* * *} \\
(0.067)\end{array}$ & & & & & & \\
\hline Lagged DV & & & & & & & $\begin{array}{c}.231 * * * \\
(.058)\end{array}$ & $\begin{array}{c}0.231 * * * \\
(0.054)\end{array}$ & $\begin{array}{c}0.186^{* * *} \\
(0.052)\end{array}$ \\
\hline $\begin{array}{l}\text { Year dummies } \\
\text { Region dummies }\end{array}$ & $\checkmark$ & $\checkmark$ & $\checkmark$ & $\checkmark$ & $\checkmark$ & $\checkmark$ & & & \\
\hline State dummies & & & & & & & $\checkmark$ & $\checkmark$ & $\checkmark$ \\
\hline$\overline{\text { Years }(\max N)}$ & 90 & 90 & 54 & 90 & 89 & 89 & 90 & 90 & 90 \\
\hline States (N) & 152 & 151 & 144 & 141 & 133 & 141 & 152 & 149 & 142 \\
\hline Observations & 8,109 & 8,035 & 5,896 & 7,218 & 6,631 & 7,217 & 8,051 & 7,977 & 7,235 \\
\hline R-squared (psendo) & 0.233 & 0.230 & 0.362 & 0.267 & 0.291 & $(0.336)$ & 0.172 & 0.181 & 0.142 \\
\hline
\end{tabular}

Outcome: regime type $(0=$ republic, $1=$ monarchy). Years: $1910-$. Reduced sample: excludes states that lost or were weakened by WWI. Right-side variables lagged fifteen years behind the outcome. Constant not reported. Clustered standard errors (by state) in parentheses $* * * \mathrm{p}<0.01,{ }^{* *} \mathrm{p}<0.05, * \mathrm{p}<0.1$

\section{Discussion}

In this paper, we have laid out a framework for understanding the rise and demise of the most 
prevalent regime type in the history of state-like forms of political organization. Monarchy, we argue, offers an efficient solution to the primordial problem of order where polities are large and citizens isolated from each other. This explains its preeminence in the pre-modern era. The efficiency of monarchy is challenged by other methods of leadership selection when communication costs are lowered. This explains its loss of appeal in the modern era.

Although it is not possible to directly test an unobservable feature of political life (coordination), we have tested several observable implications of the theory. We have shown that monarchical regimes were more territorially expansive than republics in the pre-modern era and less expansive in the modern era (Figure 3). We have shown that monarchical regimes were less prone to breakdown in the pre-modern era and more prone to breakdown in the modern era (Table 3). We have shown that monarchs enjoyed longer tenure in office in the modern era (Table 4). We have shown that monarchies were less prone to violent conflicts (internal and external) in the pre-modern era (Table 5). And we have shown that the rise of mass communications, exemplified by the radio, is associated with the demise of monarchy in the modern era (Table 6).

There is much that we do not understand about this under-studied regime type. A vast library of historical work - including troves of primary and secondary historical sources - await systematic inquiry. In particular, we need to know more about why hereditary succession was adopted in most cases and resisted in others. We need to know more about variation across different types of monarchies, including those with different rules of succession and those that evolved into constitutional monarchies. We trust that this survey of the subject will serve as an entrée for scholars to dig deeper into this under-studied research question. 


\section{References}

Acharya, Avidit, Alexander Lee. 2019. "Path Dependence in European Development: Medieval Politics, Conflict, and State Building." Comparative Political Studies Vol 52, Issue 13-14, 21712206.

Anckar, Carsten, Cecilia Fredriksson. 2016. "Political Regimes of the World, 1800-2015.”

Database, Department of Political Science, Åbo Akademi University.

Anderson, Benedict. 1991. Imagined Communities: Reflections on the Origin and Spread of Nationalism, revised ed. London: Verso.

Anderson, Lisa. 1991. “Absolutism and the Resilience of Monarchy in the Middle East.” Political Science Quarterly 106:1 (Spring) 1-15.

Anderson, Lisa. 2000. "Dynasts and nationalists: why monarchies survive." In Joseph Kostiner (ed), Middle East Monarchies (London: Westview) 53-69.

Aquinas, St. Thomas. 2012. De Regno: On Kingship To the King of Cyprus, translated by Gerald B.

Phelan, revised by I. Th. Eschmann, O.P. Veritatis Splendor Publications. Kindle Edition.

Ayalon, Ami. 2000. "Post-Ottoman Arab Monarchies: Old Bottles, New Labels?” In Joseph Kostiner, ed., Middle East Monarchies (London: Westview).

Bendix, Reinhard. 1980. Kings or People: Power and the Mandate to Rule. Berkeley: University of California Press.

Blain, Neil, Hugh O’Donnell (eds). 2001. Media, Monarchy and Power: the Postmodern Culture in Europe. Intellect.

Bodin, Jean. 1955. Six Books of the Commonwealth, abridged and translated by M.J. Tooley. Oxford: Basil Blackwell. 
Burbank, Jane, Frederick Cooper. 2010. Empires in World History: Power and the Politics of Difference. Princeton: Princeton University Press.

Burling, Robbins. 1974. The Passage of Power: Studies in Political Succession. New York: Academic Press.

Carter, David B., Curtis S. Signorino. 2010. "Back to the future: Modeling time dependence in binary data." Political Analysis 18.3: 271-292.

Castro, Joseph Justin. 2013. Wireless: Radio, revolution, and the Mexican State, 1897-1938. The University of Oklahoma Press.

Cheibub, Jose Antonio, Jennifer Gandhi, James Raymond Vreeland. 2010. "Democracy and Dictatorship Revisited.” Public Choice 143:1-2, 67-101.

Coppedge, Michael, John Gerring, Staffan I. Lindberg, Svend-Erik Skaaning, Jan Teorell, David Altman, Michael Bernhard, M. Steven Fish, Adam Glynn, Allen Hicken, Carl Henrik Knutsen, Kyle L. Marquardt, Kelly McMann, Valeriya Mechkova, Pamela Paxton, Daniel Pemstein, Laura Saxer, Brigitte Seim, Rachel Sigman, and Jeffrey Staton. 2017. "V-Dem Codebook v7.1." Varieties of Democracy (V-Dem) Project.

Crone, Patricia. 1989. Pre-Industrial Societies: Anatomy of the Pre-Modern World. Oxford: Oneworld.

Davis, Eric. 1991. “Theorizing Statecraft and Social Change in Arab Oil-producing Countries.” In Eric Davis, Nicolas Gavrielides (eds), Statecraft in the Middle East: Oil, Historical Memory, and Popular Culture (Miami: Florida International University Press) 1-35.

Davison, Walter Phillips. 1965. International political communication. Council on Foreign Relations.

Dawkins, Richard. 1978. The Selfish Gene. Oxford: Oxford University Press.

Dincecco, Mark, Massimiliano Gaetano Onorato. 2018. From Warfare to Wealth: The Military Origins of Urban Prosperity in Europe. Cambridge: Cambridge University Press. 
Djuve, Vilde, Carl Henrik Knutsen, Tore Wig. 2019. "Patterns of Regime Breakdown Since the French Revolution.” Comparative Political Studies (forthcoming).

Duindam, Jeroen. 2016. Dynasties: A Global History of Power, 1300-1800. Cambridge: Cambridge University Press.

Elias, Norbert. 1983. The Court Society. Oxford: Basil Blackwell.

Ezrow, Natasha M., Erica Frantz. 2011. Dictators and Dictatorships: Understanding Authoritarian Regimes and their Leaders. Bloomsbury.

Fawtier, Robert. 1960. The Capetian Kings of France, trans. L. Butler and R. Adam. New York: Saint Martin's Press.

Filmer, Robert. 1991. Patriarcha and other Writings, ed. Johann P. Sommerville. Cambridge: Cambridge University Press.

Gause, E. Gregory. 1994. Oil Monarchies: Domestic and Security Challenges in the Arab Gulf States. New York: Council on Foreign Relations.

Gause, E. Gregory. 2000. 'The Persistence of Monarchy in the Arabian Peninsula: A Comparative Analysis." In Joseph Kostiner, ed., Middle East Monarchies (London: Westview, 2000) 167-86.

Geddes, Barbara, Erica Frantz, Joseph Wright. 2014. “Autocratic Breakdown and Regime Transitions: A New Data Set.” Perspectives on Politics 12:2, 313-31.

Gerring, John, Tore Wig, Andreas Forø Tollefsen, Brendan Apfeld. 2018. "Harbors and Democracy.” Varieties of Democracy Working Paper SERIES 2018:70.

Gleditsch, Kristian S., Michael D. Ward. 1999. "A revised list of independent states since the Congress of Vienna." International Interactions 25.4: 393-413.

Goody, Jack, Joan Thirsk, E.P. Thompson (eds). 1979. Family and Inheritance: Rural Society in 
Western Europe, 1200-1800. Cambridge: Cambridge University Press.

Grossman, H. I., 2002. “Make Us a King': Anarchy, Predation, and the State.” European Journal of Political Economy 18, 31-46.

Habermas, Jurgen. 1991. The structural transformation of the public sphere: An inquiry into a category of bourgeois society. Cambridge: MIT press.

Hale, Julian Anthony Stuart.1975. Radio power: Propaganda and international broadcasting. London: Paul Elek.

Headrick, Daniel R. 2000. When information came of age: Technologies of knowledge in the age of reason and revolution, 1700-1850. Oxford: Oxford University Press.

Herb, Michael. 1999. All in the Family: Absolutism, Revolution, and Democracy in the Middle Eastern Monarchies. Albany, NY: SUNY Press.

Hibbert, Christopher. 1968. Charles I. London: Weidenfeld, Nicolson.

Huntington, Samuel P. 1966. “The Political Modernization of Traditional Monarchies.” Daedalus 95:3 (Summer) 763-788.

Huntington, Samuel P. 1968. Political order in changing societies. New Haven: Yale University Press.

Jones, Dan. 2013. The Plantagenets: The Warrior Kings and Queens who Made England. Penguin.

Kantorowicz, Ernst. 1957. The King's Two Bodies: A Study in Medieval Political Theology. Princeton: Princeton University Press.

Karawan, Ibrahim A. 1992. "Monarchs, Mullas, and Marshals: Islamic Regimes?" Annals of the American Academy of Political and Social Science 524 (November) 103-119.

Kechichian, Joseph A. 2001. Succession in Saudi Arabia. Palgrave Macmillan. 
King, Preston T. 1974. The Ideology of Order: A Comparative Analysis of Jean Bodin and Thomas Hobbes. London: Barnes, Noble.

Kiser, E., Yoram Barzel. 1989. “The Origins of Democracy in England.” Rationality and Society 3:4, $396-422$.

Knutsen, Carl Henrik, Jan Teorell, Tore Wig, Agnes Cornell, John Gerring, Haakon Gjerløw, Svend-Erik Skaaning, Daniel Ziblatt, Kyle L. Marquardt, Dan Pemstein, Brigitte Seim. 2019. "Introducing the Historical Varieties of Democracy Dataset: Political Institutions in the Long 19th Century." Journal of Peace Research 56:3, 440-51.

Kokkonen, Andrej, Anders Sundell. 2014. "Delivering stability: Primogeniture and autocratic survival in European monarchies 1000-1800.” American Political Science Review 108:2.

Krieger, Leonard. 1970. Kings and Philosophers 1689-1789. New York: W.W. Norton.

Kuper, Hilda. 1986. The Swazi: A South African Kingdom. New York: Holt, Rinehart, Winston. Lachaud, Frédérique, Michael Penman (eds.). 2008. Making and Breaking the Rules: Succession in Medieval Europe, c. 1000- c.1600. Turnhout.

Lewis, Bernard. 2000. "Monarchy in the Middle East.” In Joseph Kostiner, ed., Middle East Monarchies (London: Westview, 2000) 167-86.

Lucas, Russell E. 2012. "Rules and Tools of Succession in the Gulf Monarchies." Journal of Arabian Studies 2.1: 75-91.

Magaloni, Beatriz. 2008. "Credible Power-Sharing and the Longevity of Authoritarian Rule." Comparative Political Studies 41(4-5):715-741.

McDonagh, Eileen. 2015. "Ripples from the First Wave: The Monarchical Origins of the Welfare State." Perspectives on Politics 13.4: 992-1016. 
Menaldo, Victor. 2012. “The Middle East and North Africa's resilient monarchs.” Journal of Politics 74, 707-722.

Morrill, John. 2004. “Conclusion: King-Killing in Perspective.” In Robert von Friedeburg (ed), Murder and Monarchy: Regicide in European History, 1300-1800 (Palgrave Macmillan) 293-99.

Myers, Henry Allen. 1982. Medieval Kingship. Nelson-Hall.

Nelson, Janet. 1995. “Kingship and Royal Government.” In Rosamond McKitterick (ed), New Cambridge Medieval History (Cambridge: Cambridge University Press) 381-430.

North, Douglass C., Barry R. Weingast. 1989. "Constitutions and Commitment: The Evolution of Institutions Governing Public Choice in Seventeenth-Century England.” Journal of Economic History 49 (4):803-32.

North, Douglass C., John J. Wallis, Barry Weingast. 2009. Violence and Social Orders: A Conceptual Framework for Interpreting Recorded Human History. New York: Cambridge University Press.

Nussli, Christos. 2017. "Euratlas Historical Atlas and Gazetteer of Europe."

Olson, Mancur. 1993. "Dictatorship, Democracy, and Development." American Political Science Review 87:3 (September) 567-576.

Parker, Bradley J. 2011. "The Construction and Performance of Kingship in the Neo-Assyrian Empire." Journal of Anthropological Research 67:3 (Fall) 357-386.

Reynolds, Susan. 1999. "Government and Community.” In D. Luscombe \& J. Riley-Smith (eds.) The New Cambridge Medieval History (Cambridge: Cambridge University Press) 86-112.

Solorzano y Pereira, Juan de (1575-1655). 1776. Obras posthumas. Madrid: [publisher?].

Sutherland, Ingeborg. 2001. From Warlords to Kings, c.e. 1-752: In Search of Military and Political Legitimacy in Germanic Societies. PhD thesis, Department of History, Concordia University. 
Teorell, Jan, Staffan I. Lindberg. 2015. "The Structure of the Executive in Authoritarian and Democratic Regimes: Regime Dimensions across the Globe, 1900-2014.” University of Gothenburg, Varieties of Democracy Institute: Working Paper No. 5.

Tilly, Charles. 1985. "War making and state making as organized crime." In Peter B. Evans, Dietrich Rueschemeyer, Theda Skocpol (eds). Bringing the state back in (Cambridge University Press) 169-91.

Veenendaal, Wouter. 2014. “A Big Prince in a Tiny Realm: Smallness, Monarchy, and Political Legitimacy in the Principality of Liechtenstein.” Swiss Political Science Review, 21 (2), 333-349.

Wahman, Michael, Jan Teorell, Axel Hadenius. 2013. “Authoritarian Regime Types Revisited: Updated Data in Comparative Perspective.” Contemporary Politics 19(1): 19-34.

Webb, Herschel. 1968. The Japanese Imperial Institution in the Tokugawa Period. East Asian Institute Ser.

Weber, Max. 1904-05/1958. The Protestant Ethic and the Spirit of Capitalism. New York: Charles Scribner's.

Weber, Max. 1987. Economy and Society, ed. Guenther Roth and Claus Wittich vol. I, II. Berkeley: University of California Press.

Wolf, Armin. 1991. "The Family of Dynasties in Medieval Europe: Dynasties, Kingdoms and Tochterstamme." Studies in Medieval and Renaissance History 12, 185-260.

Wright, Joseph. 2008. “To invest or insure? How authoritarian time horizons impact foreign aid effectiveness." Comparative Political Studies 41 (7), 971-1000. 


\section{Appendix A: Alternatives to Monarchy in the Pre-Modern Era}

The effectiveness of a regime type is apparent only with respect to a set of envisioned alternatives. Without pretending to cover this ground in depth, we shall briefly discuss two sorts of regimes - personal dictatorships and corporate forms of governance, which may be regarded as monarchy's principal rivals (among state-like forms of political organization) during the premodern period.

Personal dictatorships were quite successful in conquering substantial swaths of territory. However, a dictator with no connection to a royal or divine family - a commoner, in other words - was not well-positioned to establish connections to traditional practices and belief-systems. Dictators were constrained to rule by force and charisma, and few leaders possessed such extraordinary qualities. Dictators were also at pains to solve the problem of succession, and tended to disintegrate fairly quickly after the death of their founders.

Among institutionalized forms of rule we may distinguish between monarchy and corporate regimes, which might be further classified as democratic or oligarchic but were in either case generally centered on an assembly (Hansen 2000: 611-12). Corporate regimes exercised power that was vested in a set of citizens or factions. This sort of power was apt to seem prosaic (lacking in supernatural sanction) and ineffectual. No special legitimacy flows from this sort of power unless and until a direct connection between leaders and citizens can be established, an achievement that awaited modern systems of transport and communications (allowing leaders to communicate directly with citizens) and political parties (allowing interests to be effectively aggregated). Corporate forms of governance in the pre-modern era generally did not provide an efficient method for identifying and empowering an executive, one who could keep order and issue authoritative decisions. Nor could they solve the perennial problem of succession.

Granted, legislatures and assemblies of ordinary citizens could serve a secondary role - as a brake on the executive. But they were not well-designed to carry the burdens of government and often served as engines of factionalism or springboards for civil conflict - a favored theme of commentators such as Machiavelli (1990: 105; see also Epstein 1999). Only rarely were legislatures or citizen assemblies able to execute affairs of state on their own initiative and to maintain a stable locus of sovereignty over an extended period (Bendix 1980; Boucoyannis 2017; Graves 2001; Marongiu 1968; Monahan 1987; Myers 1975; Ober 2015; Van Zanden, Buringh, Bosker 2010). When corporate forms of governance were successful their purview was generally limited to a small territory and to urban settings, where people lived close together and thus experienced a high level of connectedness, allowing coordination difficulties to be overcome (Crone 1989: 41-2; Hansen 2000: 611-12; Stasavage 2010, 2011, 2016). The Roman republic/empire appears to be the only sizeable polity that managed to maintain a nonmonarchical form of government over a long period of time.

It is telling that in those rare occasions where parliaments managed to wrest partial control from monarchs, the writ of the monarch was still required to legitimate rule over subject peoples beyond the home turf of the parliament. Representative parliaments might exercise sovereignty over small, relatively homogeneous areas. But in larger polities or empires, encompassing diverse peoples, the monarch's authority was indispensable. This notion is recognized in the concept of a "composite monarchy" (Elliott 1992; Henshall 2010). With respect to larger polities of early modern Europe such as France, Graves (2001: 45) remarks, "the very diversity of community loyalties, customs and traditions, political rights and local economies, as well as the size and geography of the French kingdom, worked in the long run against the likelihood of effective national or regional assemblies." The same observation might be made of Britain. While the English Parliament was an acknowledged source of power close to home, away from home - in the palatinates of Durham, Cheshire, the Isle of Man and the Channel Islands (Henshall 2010: 9-10), in the provinces of Ireland, Wales, Scotland (Grant, Stringer 1995), and 
further abroad in the New World and India (Aldrich, McCreery 2016) - the monarch served as the essential symbol of sovereignty, tying together diverse elements of a farflung polity. 


\section{Appendix B: European Monarchies, Mapped}

Maps of European states in the following figures follow Euroatlas (Nussli 2017) in their definition of states and territories, with a few minor adjustments. 
Figure B.1: European Monarchies, 1100

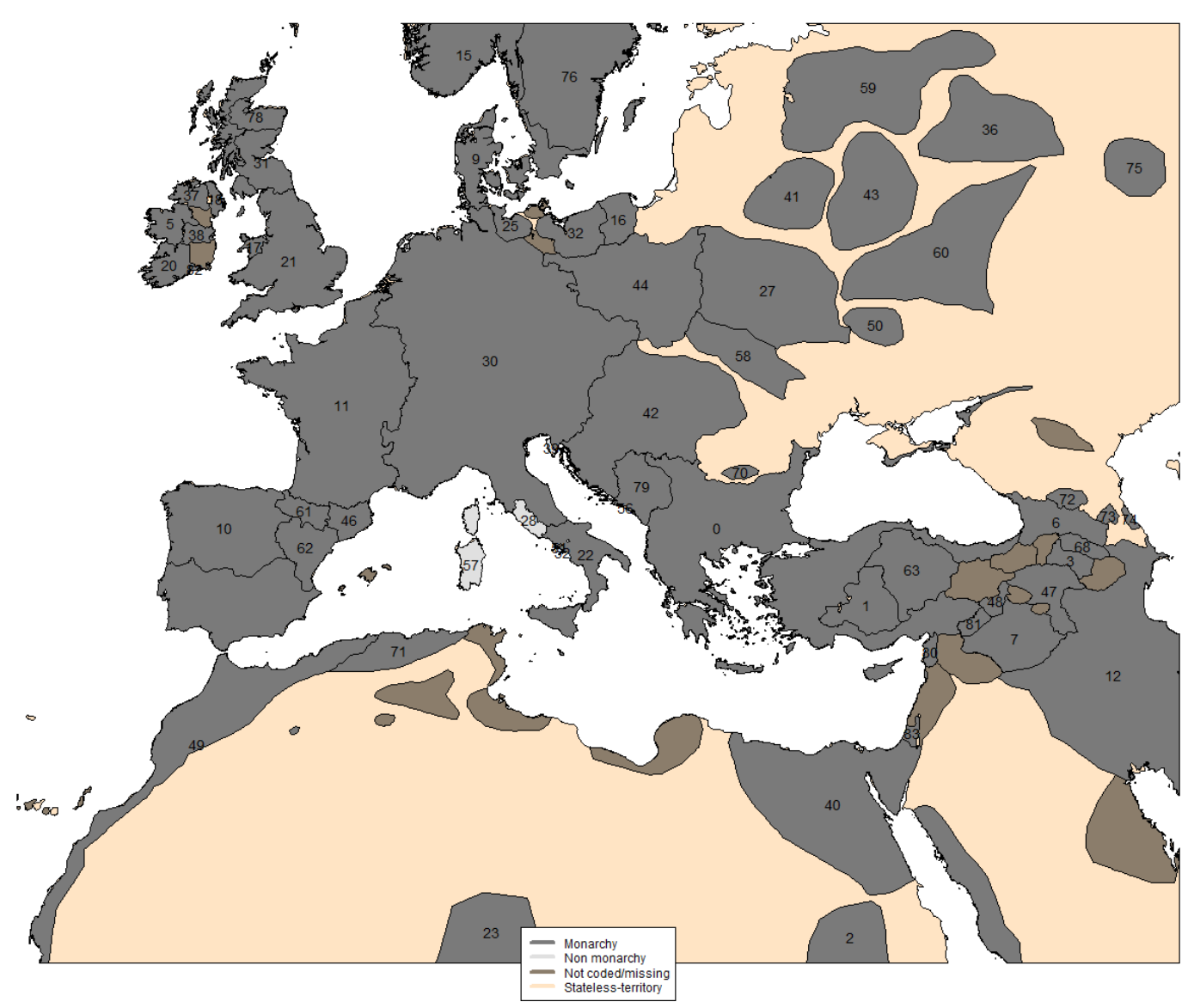

Coded states (M=monarchy, $\mathbf{R}=$ Republic): $0=$ Roman Empire $(\mathbf{M}), 1=$ Seljuk Sultanate of Rûm $(M), 2=$ Kingdom of Makuria and Nobatia $(M), 3=$ Lordship of Ani $(M), 5=\operatorname{Kingdom}$ of Connacht $(M), 6=$ Kingdom of Georgia $(M), 7=$ Emirate of Mosul (M) , 9 = Kingdom of Denmark (M), $10=$ Kingdom of León and Castile (M) , 11 = Kingdom of the Franks (M) , 12 = Abbasid Caliphate of Baghdad under Seljuk Rule (M) , 15 = Kingdom of Norway $(M), 16=$ Duchy of Pomerelia $(M)$, 17 = Kingdom of Gwynedd (M) , 18 = Kingdom of Ulaidh $(M), 20=$ Kingdom of Munster $(M), 21$ = Kingdom of England $(M)$ , $22=$ Duchy of Apulia and Calabria (M) , $23=$ Kingdom of Kanem (M) , $25=$ Obotrites Tribes Confederacy (M) , $27=$

Principality of the Kievan Rus (M) , 28 = State of the Church (R), $30=$ Empire of the Romans (M), 31 = Kingdom of Scotland $(\mathrm{M}), 32=$ Pomeranian Lordships $(\mathrm{M}), 36=$ Principality of Rostov-Suzdal $(\mathrm{M}), 37=$ Kingdom of Ailech $(\mathrm{M}), 38=$ Kingdom of Mide $(M), 39=$ Republic of Venice $(R), 40=$ Fatimid Caliphate $(M), 41=$ Principality of Polotsk $(M), 42=$ Kingdom of Hungary $(M), 43=$ Principality of Smolensk $(M), 44=$ Kingdom of Poland $(M), 46=$ County of Barcelona $(M), 47=$ Emirate of Ahlat (M), $48=$ Emirate of Amida (M) , 49 = Kingdom of the Almoravids (M) , 50 = Lordship of Pereyaslav-Rus $(\mathrm{M}), 51=$ Duchy of Naples (M) , $52=$ Duchy of Amalfi $(M), 56=$ Republic of Ragusa (R) , $57=$ Dominions of Pisa (R) , $58=$ Principality of Galicja-Volhynia (M) , 59 = Republic of Novgorod (M) , $60=$ Principality of Chernigov (M) , $61=$ Kingdom of Aragon and Navarre (M), $62=$ Lordship of Valencia $(M), 63=$ Danishmendid Emirate $(M), 68=$ Kingdom of Tashir-Dzoraget $(M), 70=$ Vlach Populations $(M), 71=$ Hammadid Kingdom of Bejaia $(M), 72=$ Kingdom of Alania $(M), 73=$ Kingdom of Sarir $(M), 74$ $=$ Emirate of Derbent $(M), 75=$ Khanate of Volga Bulgaria $(M), 76=$ Kingdom of Sweden $(M), 78=$ Kingdom of Moray $(M)$, $79=$ Kingdom of Duklja $(M), 80=$ Principality of Antioch $(M), 81=$ County of Edessa $(M), 82=$ Kingdom of Dyflin $(M), 83$ $=$ Principality of Jerusalem $(\mathrm{M})$ 
Figure B.2: European Monarchies, 1200

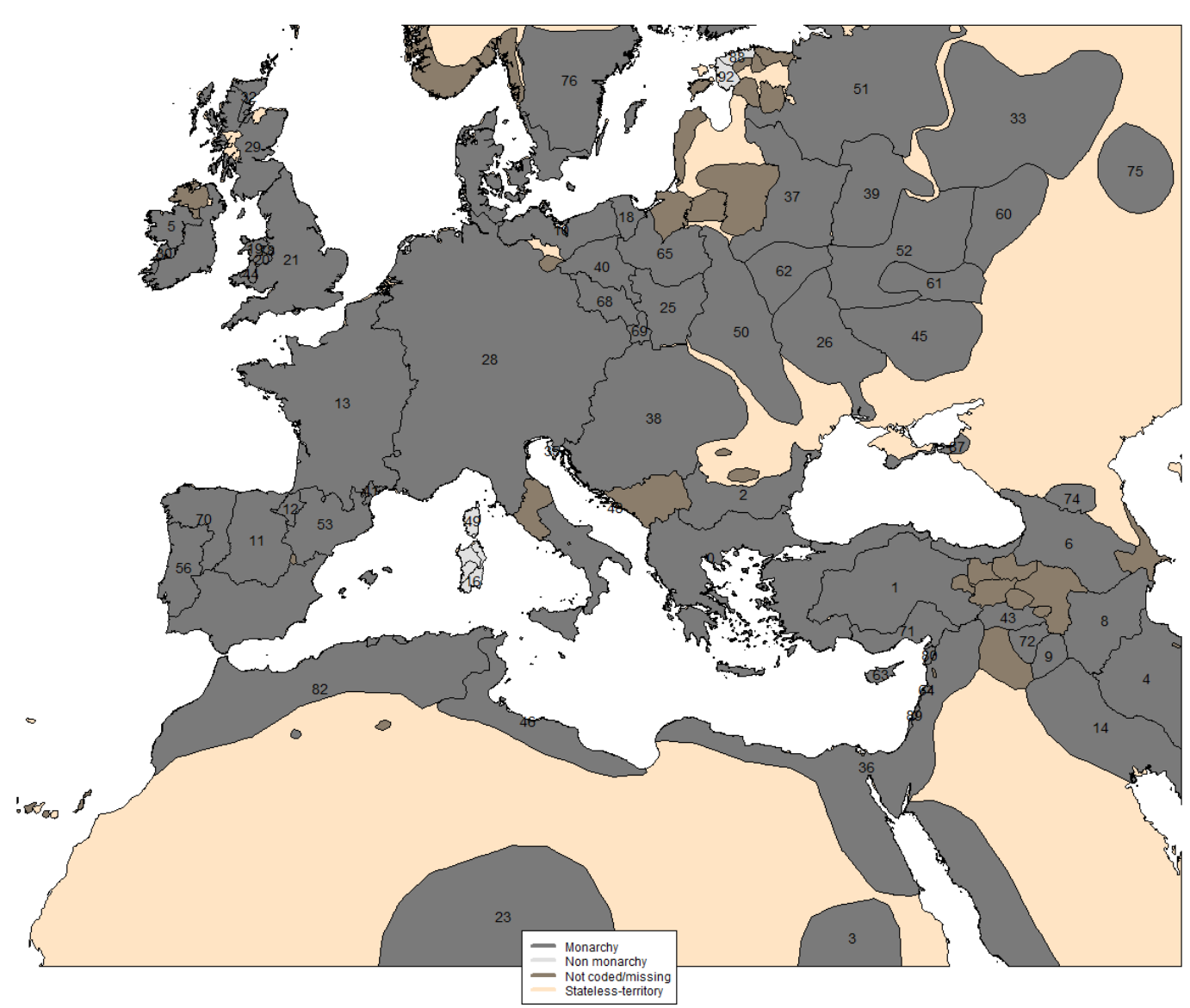

Coded states $(\mathbf{M}=$ monarchy, $\mathbf{R}=$ Republics): $0=$ Roman Empire $(M), 1=$ Seljuk Sultanate of Rûm $(M), 2=$ Kingdom of the Wallachians and Bulgarians $(M), 3=$ Kingdom of Makuria $(M), 4=\operatorname{Kingdom}$ of Khwarezm $(M), 5=$ Kingdom of Connaught (M) , $6=$ Kingdom of Georgia (M) , $8=$ Atabegs of Azerbaijan (M) , $9=$ Emirate of Mosul (M) , $10=$ Kingdom of Denmark (M) ,11 = Kingdom of Castile (M) , 12 = Kingdom of Navarre (M), $13=$ Kingdom of the Franks (M) , 14 = Abbasid Caliphate of Baghdad under Seljuk Rule (M), 16 = Republic of Genoa (R), 18 = Duchy of Pomerelia (M) , 19 = Kingdom of Gwynedd (M), 20 = Kingdom of Powys Cyfeiliog (M) , 21 = Kingdom of England (M) , $23=$ Kingdom of Kanem (M) , 25 = Principality of Cracow $(M), 26=$ Principality of Kiev (M) , $28=$ Kingdom of the Romans $(M), 29=$ Kingdom of Scotland $(M), 30=$ Kingdom of Thomond (M) , $32=$ Kingdom of Mann and the Isles $(M), 33=$ Grand Principality of Vladimir-Suzdal (M), $35=$ Republic of Venice (R) , $36=$ Dominions of the Ayyubids (M) , $37=$ Principality of Polotsk (M) , $38=$ Kingdom of Hungary $(M), 39=$ Principality of Smolensk (M) , $40=$ Duchy of Greater Poland (M) , $41=$ County of Toulouse $(\mathrm{M}), 43$ = Artuqid Emirate of Amida (M) , $44=$ Kingdom of Deheubarth (M) , $45=$ Lordship of Pereyaslav-Rus (M) , $46=$ Emirate of the Banu Ghaniya (M), $48=$ Republic of Ragusa (R) , $49=$ Dominions of Pisa (R) , $50=$ Kingdom of Galicja-Volhynia (M) , $51=$ Republic of Novgorod (M) , $52=$ Principality of Chernigov (M) , 53 = Crown of Aragon (M), 56 = Kingdom of Portugal (M), $60=$ Principality of Pereslavl-Ryazanski and Murom $(M), 61=$ Principaltiy of Novgorod-Seversk $(M), 62=$ Principality of Pinsk and Turov (M), 63 = Kingdom of Cyprus in Personal Union with the Kingdom of Jerusalem (M) , $64=$ County of Tripoli (M) , $65=$ Duchy of Masovia (M), $68=$ Duchy of Lower Silesia $(M), 69=$ Duchy of Upper Silesia $(M), 70=$ Kingdom of León $(M), 71=$ Kingdom of Armenia in Cilicia (M) , 72 = Emirate of Sinjar (M) , $74=$ Kingdom of Alania (M) , $75=$ Khanate of Volga Bulgaria $(M), 76=$ Kingdom of Sweden (M), $78=$ Kingdom of Powys Fadog (M) , 80 = Principality of Antioch (M) , 82 = Almohad Caliphate (M), 87 = Principality of Tmutarakan $(M), 88=$ County of Revala (R), $89=$ Latin Kingdom of Jerusalem in Personal Union with the Kingdom of Cyprus (M), $92=$ County of Rotalia (R) 
Figure B.3: European Monarchies, 1300

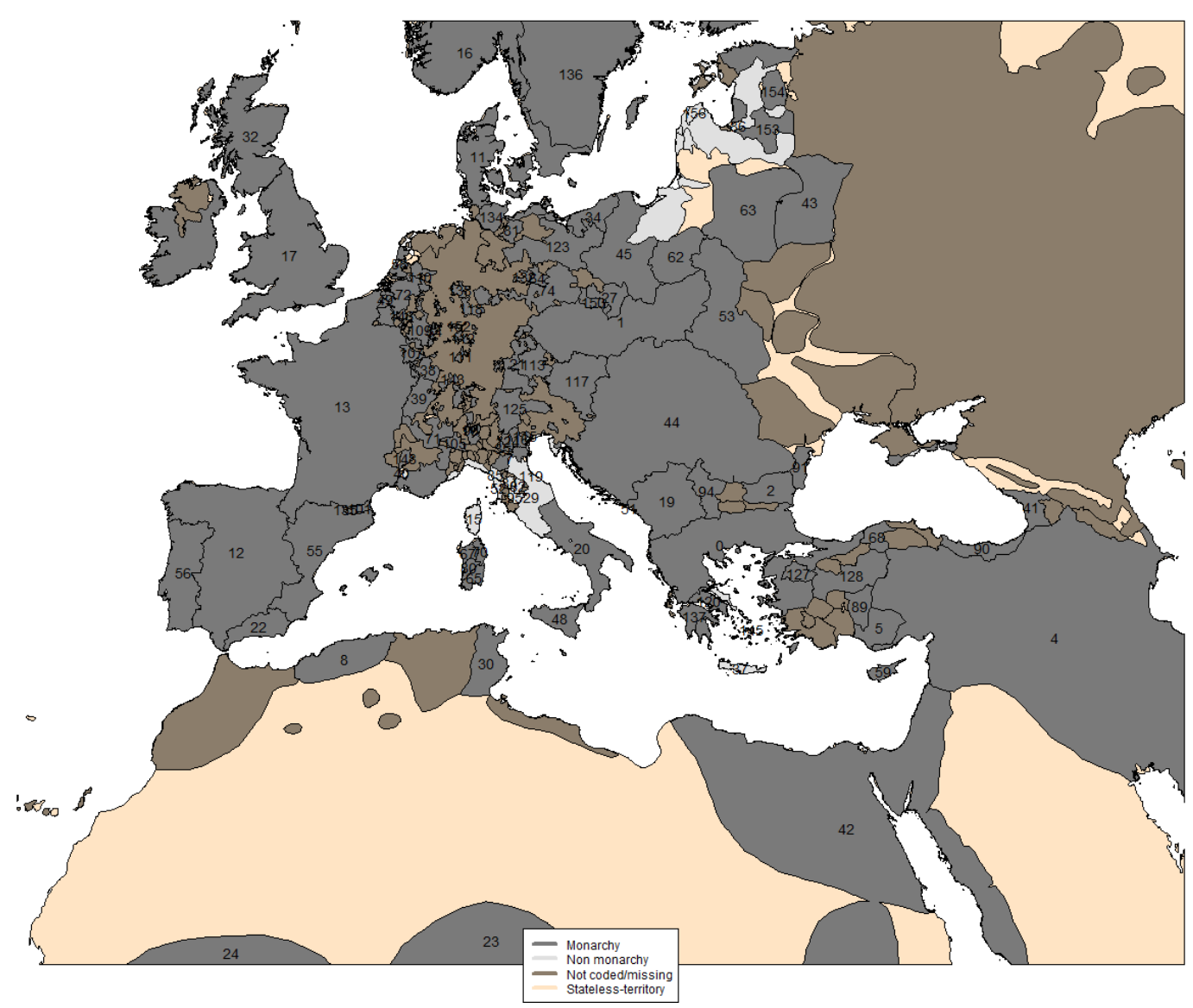

Coded states $(\mathbf{M}=$ monarchy, $\mathbf{R}=$ Republics): $0=$ Roman Empire $(\mathbf{M}), 1=$ Kingdom of Bohemia $(M), 2=$ Tsardom of Bulgaria (M) , 4 = Il Khanate of Iran (M) , $5=$ Beylik of Karaman (M) , $7=$ House of Este $(M), 8=$ Abdalwadid Kingdom of Tlemcen $(M), 11=$ Kingdom of Denmark $(M), 12=$ Crown of Castile $(M), 13=$ Kingdom of France $(M), 15=$ Republic of Genoa (R) , 16 = Kingdom of Norway $(M), 17=$ Kingdom of England (M) , $19=$ Kingdom of Ra?ka (M) , $20=$ Kingdom of Sicily in Naples (M) , 21 = Duchy of Upper Bavaria (M) , $22=$ Kingdom of Granada (M) , $23=$ Kingdom of Kanem (M) , $24=$ Kingdom of Mali (M) , 27 = Principality of Liegnitz (M), $29=$ State of the Church (R), $30=$ Hafsid Caliphate of Africa (M) , 32 = Kingdom of Scotland (M) , $34=$ Duchy of Pomerania-Wolgast $(M), 35$ = Lordship of Mantua (M) , 37 = Republic of Venice (R) , $38=$ Duchy of Lorraine (M) , 39= County of Burgundy $(M), 40=$ Principality of Orange $(M), 41=$ Kingdom of Imereti (M) , $42=$ Bahriyya Mamluk Sultanate of Egypt (M) , $43=$ Principality of Polotsk $(M), 44=$ Kingdom of Hungary $(M), 45=$ Duchy of Greater Poland and Poznan (M) , $48=$ Kingdom of Sicily (M) , $49=$ County of Flanders $(M), 51=$ Republic of Ragusa (R) , $52=$ Republic of Pisa (R) , $53=$ Kingdom of Galicia-Volhynia (M), $54=$ Electorate of Trier (M) , $55=$ Crown of Aragon (M) , $56=$ Kingdom of Portugal $(M), 58=$ Counties of Hainaut and Holland (M) , 59 = Kingdom of Cyprus (M) , $62=$ Duchy of Mazovia $(M), 63=$ Kingdom of Lithuania $(M), 64=$ Electorate of Saxony $(M), 65=$ Giudicato of Caralis $(M), 67=$ Giudicato of Logudoro (M), $68=$ Isfendiyar Beylik (M) , 70 = Giudicato of Gallura (M), $71=$ County of Savoy (M) , 72= Duchy of Brabant $(M), 74=$ Landgraviate of Thuringia and Margravate of Meissen (M), $80=$ Giudicato of Arborea $(M), 81=$ County of Schwerin $(M), 82=$ Lordship of Arezzo (R), $84=$ Republic of Florence $(\mathrm{R}), 85=$ Republic of Lucca $(\mathrm{R}), 86=$ Monastic State of the Teutonic Knights (R), $89=$ Beylik of Eshref (M) , $90=$ Empire of Trebizond (M) , $91=$ Principality of Karvuna (M) , 94 $=$ Despotate of Vidin $(M), 95=$ Republic of Siena $(R), 96=$ Lordship of Milan $(M), 101=$ Kingdom of Majorca $(M), 105=$ Margravate of Montferrat (M) , $107=$ Duchy of Bar (M) , $109=$ County of Luxemburg (M) , $110=$ County of Guelders (M) , 111 $=$ Margravate of Baden $(M), 112=$ Palatine Electorate $(M), 113=$ Duchy of Lower Bavaria $(M), 115=$ Lordship of Treviso $(M)$ ,116 = Lordship of Padua (M) , $117=$ Habsburg Dominions (M) , $118=$ Landgraviate of Hesse (M), $119=$ Republic of San Marino (R), $120=$ Duchy of Athens $(\mathrm{M}), 123=$ Margravate of Brandenburg $(\mathrm{M}), 124=$ Lordship of Verona $(\mathrm{M}), 125=$ County of Gorizia (M), $127=$ Beylik of Karesi (M) , $128=$ Beylik of Germiyan (M) , $132=$ Principality of Anhalt (M) , $134=$ County of Holstein (M) , $135=$ Co-Principality of Andorra under the Bishop of La Seu d'Urgell and the Count of (M), $136=$ Kingdom of Sweden $(M), 137=$ Principality of Achaia $(M), 138=$ Electorate of Cologne $(M), 143=$ County of Freiburg $(M)$, $145=$ Duchy of Naxos (M) , $146=$ County of Namur (M), $148=$ County of Valentinois (M) , 150 = Lordship of Schweidnitz (M) , 152 = Electorate of Mainz (M) , 153 = Archbishopric of Riga (M) , $154=$ Bishopric of Dorpat (M) , $156=$ Bishopric of Courland (R) 


\section{Figure B.4: European Monarchies, 1400}

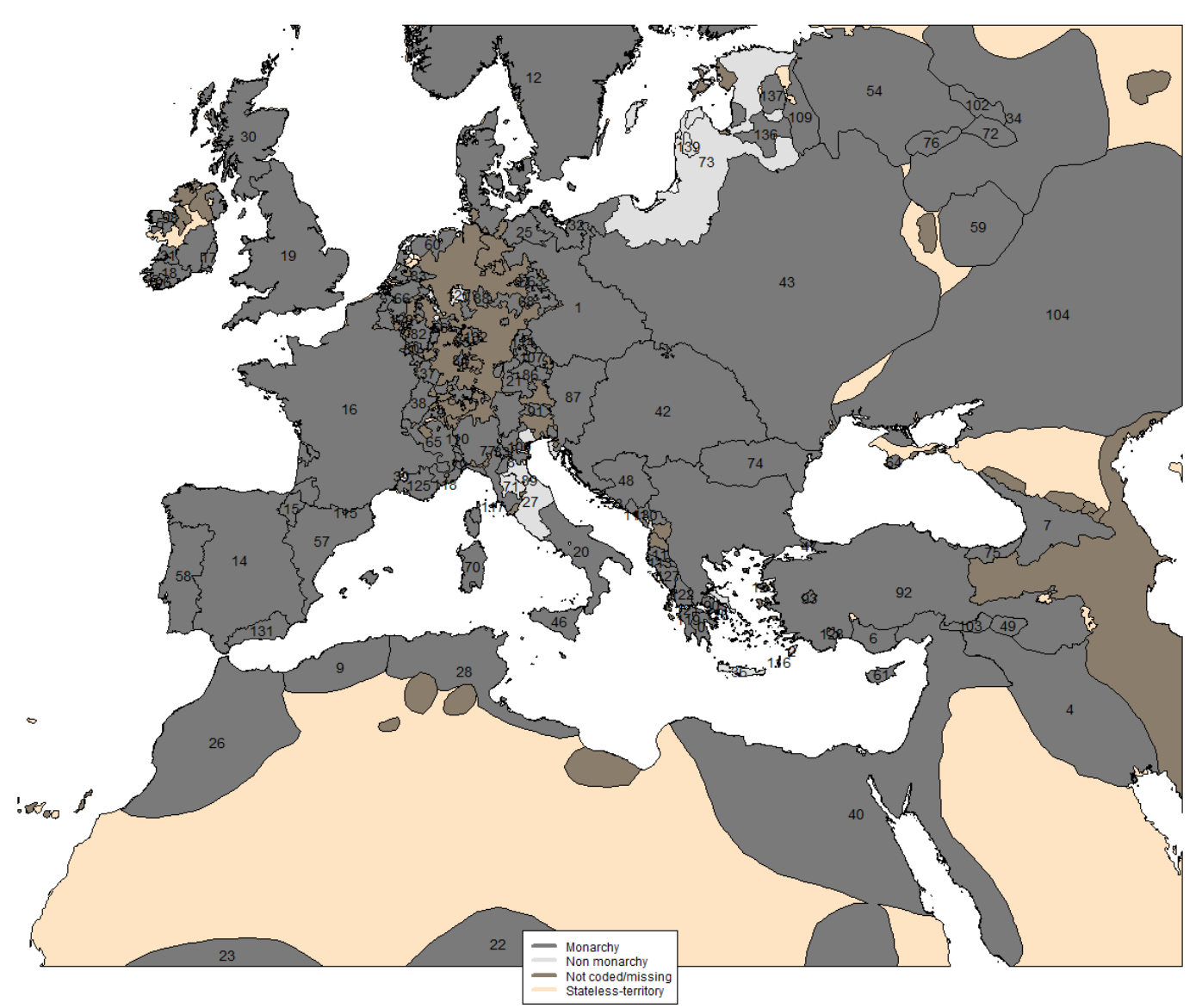

Coded states $(\mathbf{M}=$ monarchy, $\mathbf{R}=$ Republics): $0=$ Roman Empire $(\mathbf{M}), 1=$ Crown of Bohemia $(\mathbf{M}), 2=$ Military Hospitaller Order of St. John of Rhodes (R) , 4 = Jalayirid Sultanate (M) , $5=$ Lordship of Connacht in Mayo (M) , 6 = Emirate of Karaman ( M) , 7 = Kingdom of Georgia $(M), 8=$ House of Este $(M), 9=$ Abdalwadid Kingdom of Tlemcen $(M), 11=$ Lordship of Berat (M) , 12 = Kalmar Union between the Kingdoms of Denmark, Sweden and Norway (M) , $14=$ Crown of Castile (M), $15=$ King dom of Navarre $(M), 16=$ Kingdom of France $(M), 17=\operatorname{Kingdom}$ of Leinster $(M), 18=$ Earldom of Desmond $(M), 19=\operatorname{Kin}$ gdom of England (M) , 20 = Kingdom of Naples (M) , 21 = Duchy of Upper Bavaria-Munich (M) , 22 = Kingdom of Kanem (M) , 23 = Kingdom of Mali (M) , 25 = Duchy of Mecklenburg (M) , 26 = Kingdom of Maghreb (M) , 27 = State of the Church (R), $28=$ Hafsid Caliphate of Africa $(M), 30=$ Kingdom of Scotland $(M), 31=$ Kingdom of Thomond $(M), 32=$ Duchy of Pomera nia of Stettin (M), 33 = County of Mantua (M) , $34=$ Grand Duchy of Vladimir (M) , $36=$ Republic of Venice (R), $37=$ Duchy of Lorraine (M) , 38 = Lordships of the House of Burgundy (M) , $39=$ Principality of Orange $(M)$, 40 = Sultanate of Egypt $(M)$, $42=$ Kingdom of Hungary $(M), 43=$ United Kingdom of Poland and Lithuania $(M), 46=$ Kingdom of Sicily $(M), 47=$ City of Galata (R) , 48 = Kingdom of Bosnia (M) , $49=$ Emirate of Mardin (M) , $53=$ Republic of Ragusa $(R), 54=$ Principality of Novg $\operatorname{orod}(M), 56=$ Electorate of Trier $(M), 57=$ Crown of Aragon $(M), 58=$ Kingdom of Portugal $(M), 59=$ Principality of Peresl avl-Ryazanski (M) , 60 = Counties of Hainaut and Holland (M) , 61 = Kingdom of Cyprus (M) , 63 = Electorate of Saxony (M) , 6 4 = Principality of Theodoro $(M), 65=$ County of Savoy $(M), 66=$ Duchy of Brabant $(M), 68=$ Landgraviate of Thuringia and Margravate of Meissen (M) , $70=$ Giudicato of Arborea (M), $71=$ Republic of Florence (R) , $72=$ Principality of Rostov (M) , 73 $=$ Monastic State of the Teutonic Knights $(\mathrm{R}), 74=$ Principality of Wallachia $(\mathrm{M}), 75=$ Empire of Trebizond $(\mathrm{M}), 76=$ Principa lity of Tver (M) , 77 = Duchy of Milan (M), $79=$ Margravate of Montferrat $(M), 80=$ Duchy of Bar $(M), 82=$ Duchy of Luxem bourg $(M), 83=$ Duchy of Guelders $(M), 84=$ Margravate of Baden $(M), 85=$ Electoral Palatinate $(M), 86=$ Duchy of Lower Bavaria-Landshut $(M), 87=$ Habsburg Dominions $(M)$, $88=$ Landgraviate of Hesse $(M), 89=$ Republic of San Marino (R) , 90 $=$ Duchy of Athens $(\mathrm{M}), 91=$ County of Gorizia and Gradisca $(\mathrm{M}), 92=$ Sublime Ottoman State $(\mathrm{M}), 93=$ Beylik of Germiyan (M) , 97 = Principality of Anhalt (M), 98 = Lordship of Connacht in Sligo Under the O Conor Sligo (M) , $100=$ Lordship of Pad ua (M) , $102=$ Principality of Yaroslavl (M) , $103=$ Beylik of Dulkadir (M) , $104=$ Territories of the Golden Horde in Conflict ( M) , 106 = Mac Carthy Mor Lordship (M) , 107 = Duchy of Lower Bavaria in Straubing (M) , $109=$ Republic of Pskov (M) , 110 = Principality of Masserano $(M), 111=$ Republic of $\operatorname{Kotor}(\mathrm{R}), 113=$ Despotate of Valona $(\mathrm{M}), 114=$ Upper Palatinate $(\mathrm{M}), 11$ $5=$ Co-Principality of Andorra under the Bishop of La Seu d'Urgell and the Count of (M) , $116=$ Lordship of Karpathos (M) , 11 7 = Lordship of Piombino (M) , $118=$ Lordship of Monaco (M) , $119=$ Principality of Achaia $(M), 120$ = Electorate of Cologne (R) , 121 = Archbishopric of Patras (M) , $122=$ Despotate of Arta (M) , $123=$ Lordship of Lesbos (M) , 125 = County of Proven ce $(M), 126=$ Lordship of Aegina and Salamine $(M), 127=$ Despotate of Epirus (M) , $128=$ Beylik of Tekke $(M), 129=$ County 
of Namur (M), $130=$ Lordship of Zeta and The Sea (M) , $131=$ Kingdom of Granada (M) , 132 = Electorate of Mainz (M) , 136 $=$ Archbishopric of Riga (M) , 137 = Bishopric of Dorpat (M) , $139=$ Bishopric of Courland $(\mathrm{R})$ 


\section{Figure B.5: European Monarchies, 1500}

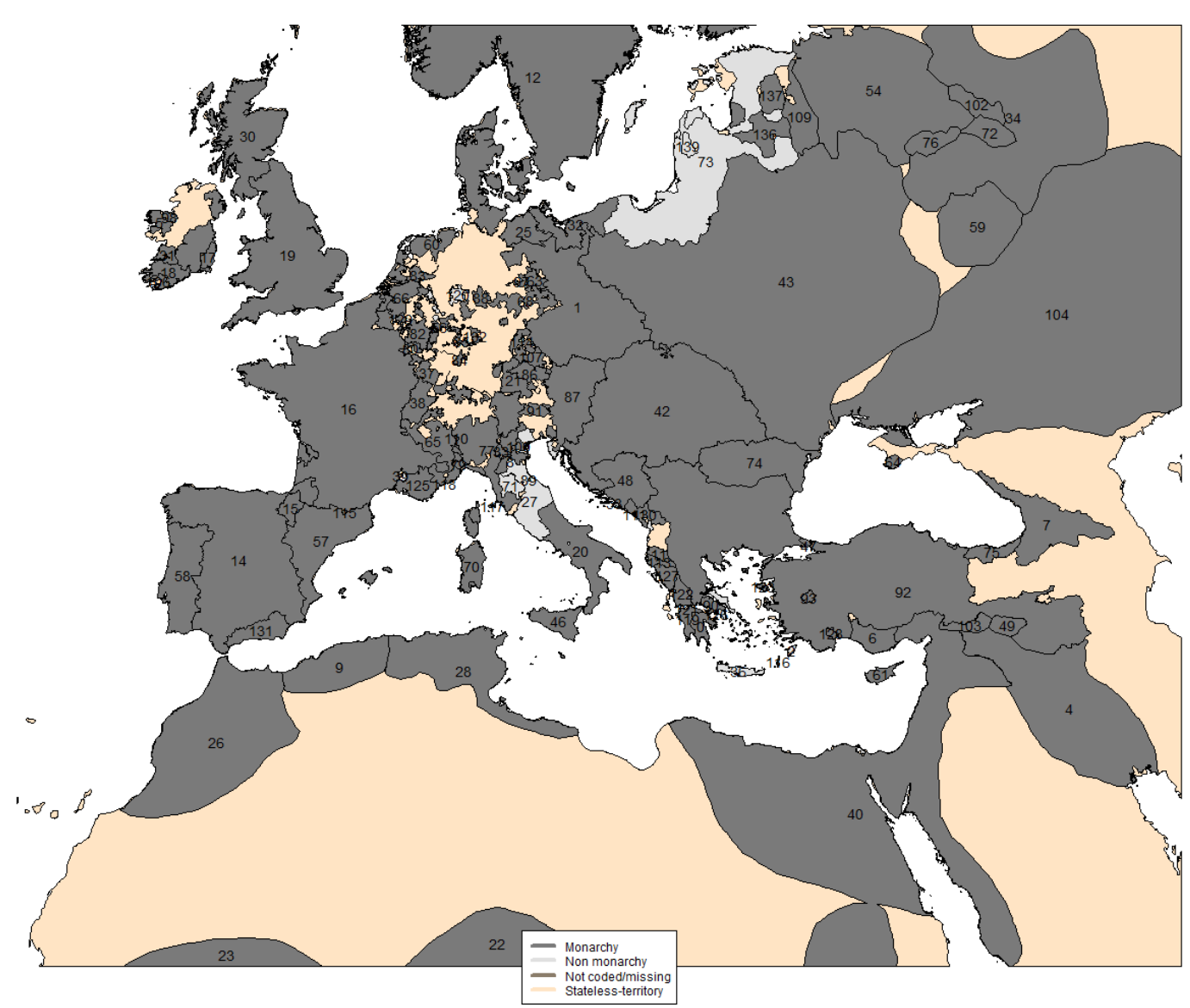

Coded states (M=monarchy, $\mathbf{R}=$ Republics): $0=$ Roman Empire $(M), 1=$ Crown of Bohemia $(M), 2=$ Military Hospitaller Order of St. John of Rhodes (R) , 4 = Jalayirid Sultanate (M) , $5=$ Lordship of Connacht in Mayo (M) , $6=$ Emirate of Karaman (M) , 7 = Kingdom of Georgia $(M), 8=$ House of Este $(M), 9=$ Abdalwadid Kingdom of Tlemcen $(M), 11=$ Lordship of Berat (M), 12 = Kalmar Union between the Kingdoms of Denmark, Sweden and Norway (M) , $14=$ Crown of Castile $(\mathrm{M}), 15=$ Kingdom of Navarre $(M), 16=$ Kingdom of France $(M), 17=$ Kingdom of Leinster $(M), 18=$ Earldom of Desmond $(M), 19=$ Kingdom of England (M), 20 = Kingdom of Naples (M), 21 = Duchy of Upper Bavaria-Munich $(M), 22=$ Kingdom of Kanem (M) , 23 = Kingdom of Mali (M) , $25=$ Duchy of Mecklenburg (M) , 26 = Kingdom of Maghreb (M) , 27 = State of the Church (R) , 28 = Hafsid Caliphate of Africa (M) , $30=$ Kingdom of Scotland (M) , $31=$ Kingdom of Thomond (M), $32=$ Duchy of Pomerania of Stettin $(M), 33=$ County of Mantua $(M), 34=$ Grand Duchy of Vladimir $(M), 36=$ Republic of Venice $(R), 37=$ Duchy of Lorraine $(M), 38$ = Lordships of the House of Burgundy $(M), 39=$ Principality of Orange $(M), 40=$ Sultanate of Egypt (M) , 42 = Kingdom of Hungary (M) , $43=$ United Kingdom of Poland and Lithuania $(M), 46=$ Kingdom of Sicily $(M)$, $47=$ City of Galata $(\mathrm{R}), 48=$ Kingdom of Bosnia $(\mathrm{M}), 49=$ Emirate of Mardin $(\mathrm{M}), 53=$ Republic of Ragusa $(\mathrm{R}), 54=$ Principality of Novgorod $(M), 56=$ Electorate of Trier $(M), 57=$ Crown of Aragon $(M), 58=$ Kingdom of Portugal $(M), 59=$ Principality of Pereslavl-Ryazanski $(M), 60=$ Counties of Hainaut and Holland $(M), 61=$ Kingdom of Cyprus $(M), 63=$ Electorate of Saxony $(M), 64=$ Principality of Theodoro $(M), 65=$ County of Savoy $(M), 66=$ Duchy of Brabant $(M), 68=$ Landgraviate of Thuringia and Margravate of Meissen $(M), 70=$ Giudicato of Arborea $(M), 71=$ Republic of Florence $(R), 72=$ Principality of Rostov (M) , $73=$ Monastic State of the Teutonic Knights (R), $74=$ Principality of Wallachia (M) , $75=$ Empire of Trebizond (M), $76=$ Principality of Tver (M) , 77 = Duchy of Milan (M), $79=$ Margravate of Montferrat $(M), 80=$ Duchy of Bar (M) , 82 = Duchy of Luxembourg (M), 83 = Duchy of Guelders (M), $84=$ Margravate of Baden (M) , $85=$ Electoral Palatinate $(M), 86=$ Duchy of Lower Bavaria-Landshut $(M), 87=$ Habsburg Dominions $(M), 88=$ Landgraviate of Hesse $(M)$, $89=$ Republic of San Marino (R), $90=$ Duchy of Athens (M), 91 = County of Gorizia and Gradisca (M), $92=$ Sublime Ottoman State (M) , $93=$ Beylik of Germiyan (M) , $97=$ Principality of Anhalt (M) , $98=$ Lordship of Connacht in Sligo Under the O Conor Sligo (M), $100=$ Lordship of Padua (M), $102=$ Principality of Yaroslavl (M) , $103=$ Beylik of Dulkadir (M), $104=$ Territories of the Golden Horde in Conflict (M) , $106=$ Mac Carthy Mor Lordship (M) , $107=$ Duchy of Lower Bavaria in Straubing (M) , $109=$ Republic of Pskov (M), $110=$ Principality of Masserano (M) , $111=$ Republic of Kotor $(\mathrm{R}), 113=$ Despotate of Valona $(M), 114=$ Upper Palatinate $(M), 115=$ Co-Principality of Andorra under the Bishop of La Seu d'Urgell and the Count of $(M), 116=$ Lordship of Karpathos $(M), 117=$ Lordship of Piombino $(M), 118=$ Lordship of Monaco $(M)$, $119=$ Principality of Achaia (M) , $120=$ Electorate of Cologne (R) , $121=$ Archbishopric of Patras (M) , $122=$ Despotate of Arta (M) , $123=$ Lordship of Lesbos (M) , $125=$ County of Provence $(M), 126=$ Lordship of Aegina and Salamine $(M), 127=$ Despotate of Epirus (M), 128 = Beylik of Tekke (M), $129=$ County of Namur (M), $130=$ Lordship of Zeta and The Sea (M), 131 = Kingdom of Granada (M), 132 = Electorate of Mainz $(M), 136=$ Archbishopric of Riga $(M), 137$ = Bishopric of Dorpat (M), $139=$ Bishopric of Courland (R) 
Figure B.6: European Monarchies, 1600

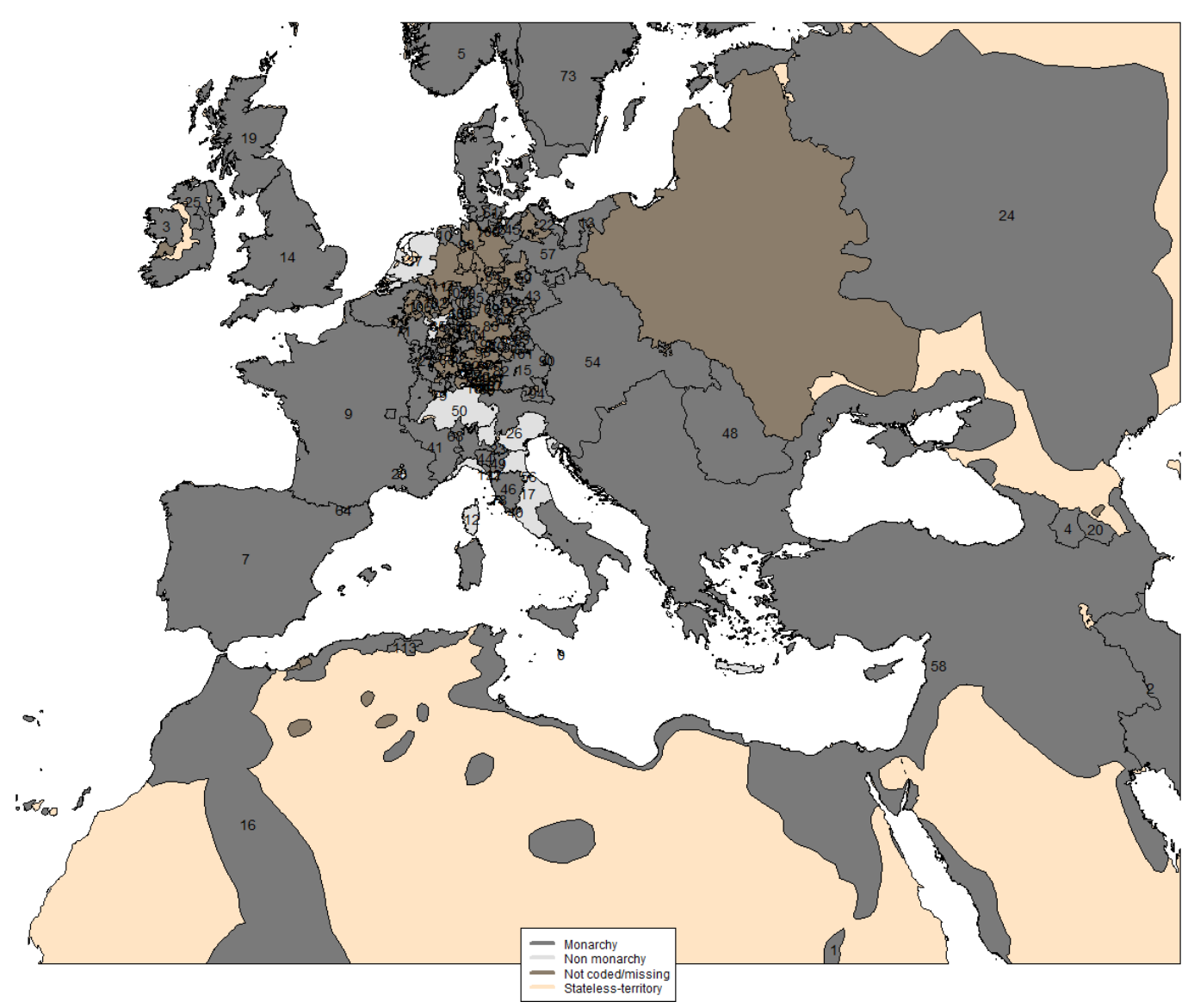

Coded states $(\mathbf{M}=$ monarchy, $\mathbf{R}=$ Republics): $0=$ Order of Saint John of Malta (R), $1=$ Sultanate of Funj $(M), 2=$ Safavid Empire of Persia (M) , $3=$ Lordship of Connacht $(M)$, $4=$ Kingdom of Kartli (M) , $5=$ Kingdom of Denmark (M) , $6=$ Duchy of Palatinate-Neuburg $(M), 7=$ Spanish Monarchy $(M), 8=$ Principality of Anhalt-Bernburg $(M), 9=\operatorname{Kingdom}$ of France $(M)$, $10=$ County of East Friesland (M), $12=$ Republic of Genoa (R) , $13=$ Duchy of Pomerania of Stettin (M), $14=$ Kingdom of England $(M), 15=$ Duchy of Bavaria $(M), 16=$ Kingdom of Morocco $(M), 17=$ State of the Church $(R), 19=$ Kingdom of Scotland (M) , 20 = Kingdom of Kakheti (M) , $22=$ Duchy of Pomerania of Wolgast (M) , $23=$ Duchy of Mantua (M) , $24=$ Tsardom of Muscovy (M) , $25=$ Earldom of Tyrone (M) , $26=$ Republic of Venice $(R), 27=$ Duchy of Lorraine $(M), 28=$ Principality of Orange (M) , $30=$ County of Waldeck (M) , $35=$ Electorate of Trier (R), $36=$ Palatine County of Sulzbach (M), $37=$ Republic of the Seven United Netherlands (R) , $39=$ Saxon Duchies, Weimar Branch (M) , $40=$ Duchy of Castro (M) , $41=$ Duchy of Savoy $(M), 43$ = Electorate of Saxony $(M), 44=$ Duchy of Parma $(M), 45=$ Duchy of Mecklenburg-Schwerin $(M), 46$ $=$ Grand-Duchy of Tuscany (M) , 47 = Lordship of Lucca (R), $48=$ Principality of Wallachia (M) , 49 = Duchy of Modena (M), $50=$ Swiss Confederation $(\mathrm{R}), 52=$ Margravate of Baden $(\mathrm{M}), 53=$ Electoral Palatinate $(\mathrm{M}), 54=$ Habsburg Monarchy $(\mathrm{M}), 55$ = Landgraviate of Hesse-Kassel (M) , $56=$ Republic of San Marino (R) , 57 = Electorate of Brandenburg (M), $58=$ Sublime Ottoman State (M) , 59 = Principality of Anhalt-Zerbst (M) , $60=$ Imperial City of Leutkirch (R), 61 = Duchy of SchleswigHolstein-Gottorp (M) , 63 = Principality of Masserano (M), 64 = Co-Principality of Andorra under the Bishop of La Seu d'Urgell and the King of F (M), 65 = Lordships of the House of Nassau (M) , 66 = Landgraviate of Hesse-Darmstadt (M), $67=$ County of Hohenzollern-Sigmaringen (M), 68 = Saxon Duchies, Coburg Branch (M) , $69=$ Duchy of Saxe-Eisenach (M) , $70=$ Margravates of Brandenburg-Ansbach and Brandenburg-Kulmbach (M), $71=$ Principality of Sedan and Bouillon $(\mathrm{M}), 73=$ Kingdom of Sweden (M) , 74 = County of Hohenzollern-Hechingen (M) , $75=$ Duchy of Saxe-Lauenburg (M) , $77=$ PrinceBishopric of Ratzeburg (R), $78=$ Principality of Piombino (M), $79=$ Prince-Bishopric of Basel $(\mathrm{R}), 80=$ Imperial City of Frankfurt (R), $81=$ Imperial City of Lindau (R) , $82=$ Imperial City of Augsburg (R), 84 = Imperial City of Goslar (R) , $85=$ Imperial City of Schweinfurt $(R), 86=$ Alliance of Ten Towns in Alsace $(R), 87=$ Imperial City of Kaufbeuren $(R), 88=$ Imperial City of Isny (R), $89=$ Imperial City of Biberach (R), $90=$ Prince-Bishopric of Passau (M), 91 = Imperial City of Memmingen (R), $92=$ Imperial City of Reutlingen (R) , $93=$ Imperial City of Bremen (R), $94=$ Archbishopric of Salzburg (M), $95=$ Imperial City of Nuremberg $(R), 96=$ Imperial City of Rothenburg $(R), 97=$ Imperial City of Ulm (R), $98=$ Imperial City of Schwabisches Hall (R), 100 = Imperial City of Buchhorn (R), $101=$ Imperial City of Regensburg (R) , $102=$ Imperial City of Cologne (R) , 103 = Electorate of Cologne (M) , $106=$ Imperial City of Aachen (R), $107=$ Imperial City of Kempten (R) , $108=$ Imperial City of Wetzlar (R), $109=$ Imperial City of Hamburg (R), $111=$ Imperial City of Dortmund (R) , $112=$ Duchy of Massa and Carrara (M) , $113=$ Kingdom of Labbes (M) , $114=$ Electorate of Mainz (M) 
Figure B.7: European Monarchies, 1700

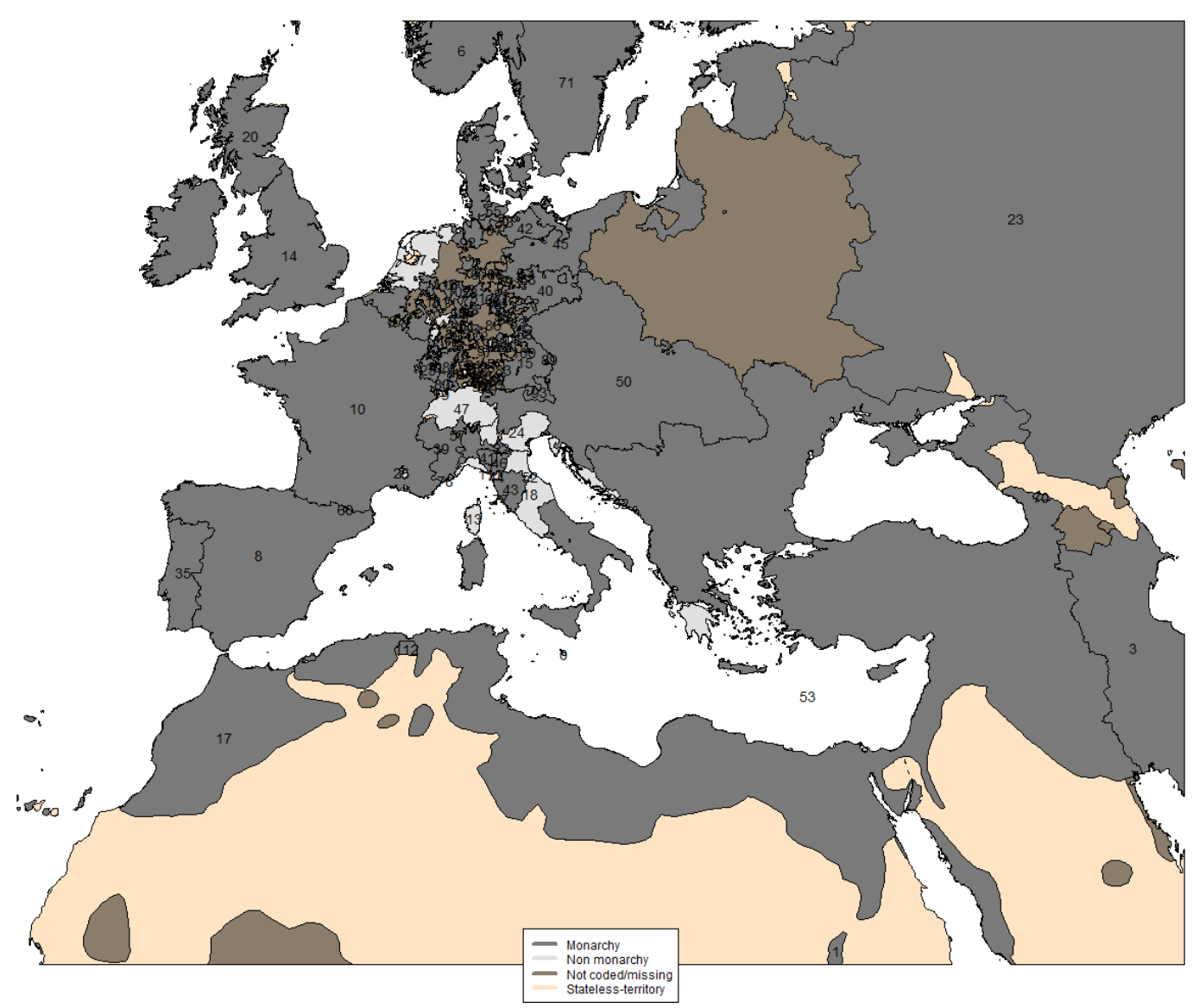

Coded states (M=monarchy, $\mathbf{R}=$ Republics): $0=$ Order of Saint-John of Malta $(\mathrm{R}), 1=$ Sultanate of Funj $(\mathrm{M}), 3=$ Sefevid Empire of Persia (M) , $6=$ Kingdom of Denmark $(M), 8=$ Spanish Monarchy $(M), 9=$ Principality of Anhalt-Bernburg $(M), 10$ $=$ Kingdom of France $(\mathrm{M}), 13=$ Republic of Genoa $(\mathrm{R}), 14=$ Kingdom of England and Ireland in Personal Union with the Kingdom of Scotland an (M), $15=$ Electorate of Bavaria (M), $17=$ Empire of Fez and Morocco (M) , $18=$ State of the Church (R) , $20=$ Kingdom of Scotland in Personal Union with the Kingdom of England and Ireland an $(M), 22=$ Duchy of Mantua (M) , 23 = Tsardom of Rus (M) , 24 = Republic of Venice (R) , 25 = Duchy of Lorraine (M) , 26 = Principality of Orange (M), 28 $=$ Principality of Waldeck-Pyrmont (M), $32=$ Republic of Ragusa (R), $33=$ Margravate of Brandenburg-Bayreuth $(M), 34=$ Electorate of Trier (R) , $35=$ Kingdom of Portugal (M) , 36 = Principality of Hohenzollern-Sigmaringen (M) , $37=$ Republic of the Seven United Netherlands in Personal Union with the Kingdom of E (R) , $38=$ Duchy of Saxe-Hildburghausen (M), $39=$ Duchy of Savoy (M), 40 = Electorate of Saxony in Personal Union with the Polish-Lithuanian Commonwealth (M), $41=$ Duchy of Parma and Piacenza (M) , $42=$ Duchy of Mecklenburg (M) , $43=$ Grand-Duchy of Tuscany (M) , 44 = Lordship of Lucca (R), $45=$ Duchy of Prussia and Margraviate of Brandenburg $(M), 46=$ Duchy of Modena and Reggio $(M), 47=$ Swiss Confederation (R) , $49=$ Margravate of Baden (M) , $50=$ Habsburg Monarchy (M) , $51=$ Landgraviate of Hesse-Kassel (M) , $52=$ Republic of San Marino (R), 53 = Sublime Ottoman State (M) , 54 = Principality of Anhalt-Zerbst (M) , 55 = Duchy of Schleswig-HolsteinGottorp (M), $57=$ Principality of Masserano (M) , $58=$ Duchy of Palatinate-Sulzbach (M) , $60=$ Co-Principality of Andorra under the Bishop of La Seu d'Urgell and the King of F (M) , 62 = Lordships of the House of Nassau (M) , 63 = Landgraviate of Hesse-Darmstadt (M), 64 = Duchy of Saxe-Gotha-Altenburg (M) , 65 = Duchy of Saxe-Coburg (M) , 66 = Duchy of SaxeEisenach (M), $68=$ Principality of Anhalt-Dessau (M) , $69=$ Margravate of Brandenburg-Ansbach $(M), 70=$ Principality of Svaneti (M), $71=$ Kingdom of Sweden (M) , $72=$ Duchy of Saxe-Meiningen (M) , $73=$ Prince-Bishopric of Ratzeburg $(M), 75=$ Principality of Hohenzollern-Hechingen $(M), 76=$ County of Lippe $(M), 77=$ Principality of Piombino $(M), 78=$ Principality of Monaco (M), $79=$ Prince-Bishopric of Basel (R) , $80=$ Allied City of Mulhouse (R), $81=$ Imperial City of Frankfurt (R), $82=$ Imperial City of Lindau (R) , 83 = Imperial City of Augsburg (R), 85 = Imperial City of Goslar (R), 86 = Imperial City of Schweinfurt (R) , $87=$ Imperial City of Kaufbeuren (R), $88=$ Imperial City of Biberach (R) , 89 = Prince-Bishopric of Passau (M) , $90=$ Imperial City of Memmingen (R), $91=$ Imperial City of Reutlingen (R), $92=$ Imperial City of Bremen (R), $93=$ Archbishopric of Salzburg (M), $94=$ Imperial City of Nuremberg (R), $95=$ Imperial City of Rothenburg (R), $96=$ Imperial City of Ulm (R), 97 = Imperial City of Schwabisches Hall (R), $99=$ Imperial City of Buchhorn (R) , $100=$ Imperial City of Regensburg (R), 101 = Imperial City of Cologne (R), 102 = Electorate of Cologne (M), 103 = Imperial City of Rottweil (R), 105 = Imperial City of Kempten (R), $106=$ Imperial City of Wetzlar (R), $107=$ Imperial City of Hamburg (R), $108=$ Principality of Salm-Salm (M) , $110=$ Imperial City of Dortmund (R) , $111=$ Duchy of Massa and Carrara (M) , 112= Kalaat of the Beni Abbes $(\mathrm{M}), 113$ = Electorate of Mainz $(\mathrm{M})$ 


\section{Figure B.8: European Monarchies, 1800}

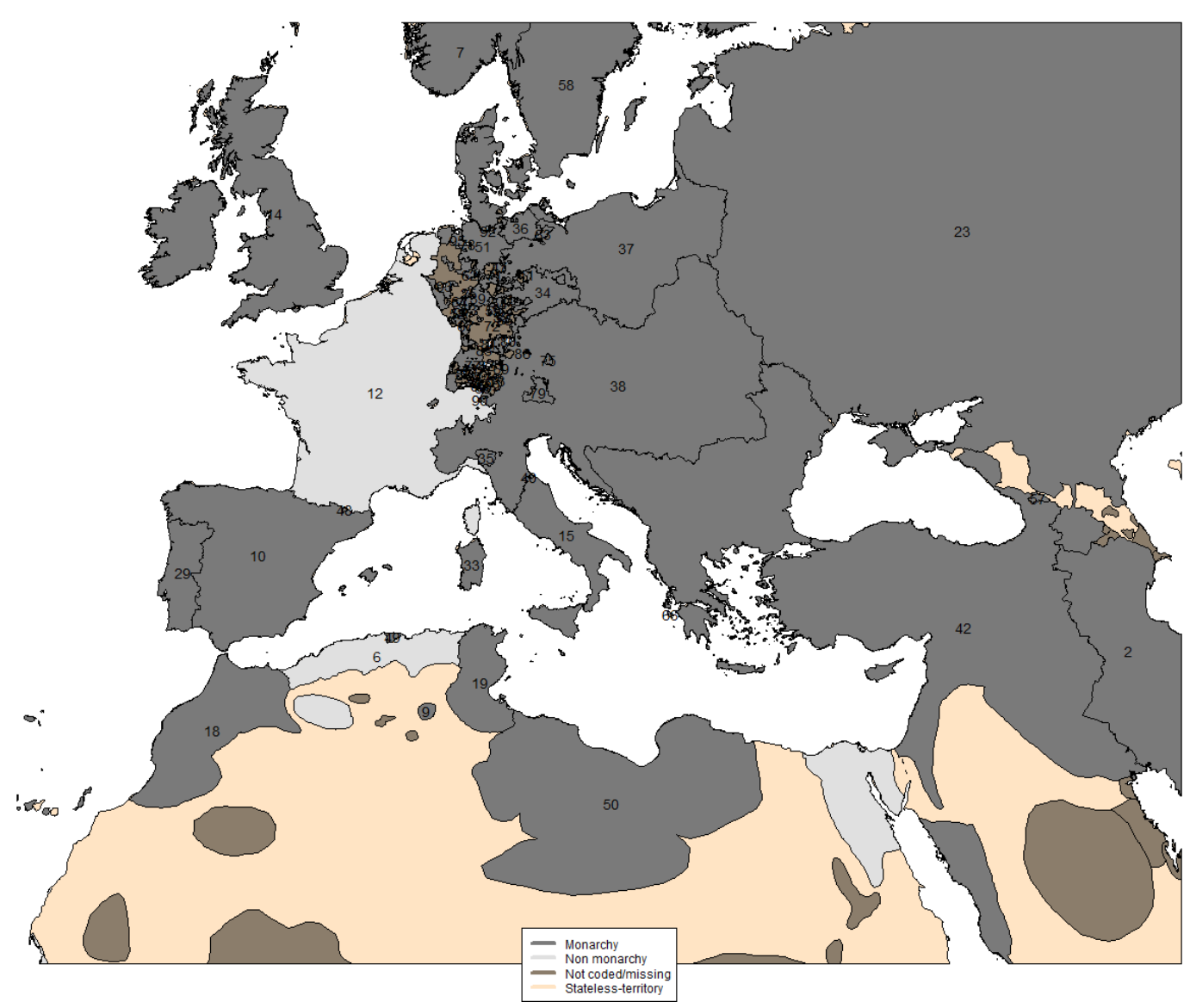

Coded states (M=monarchy, $\mathbf{R}=$ Republic): $1=$ Duchy of Saxe-Weimar $(M), 2=$ Qajar Empire of Persia $(M), 6=$ Algiers Regency (R), 7 = Kingdom of Denmark (M) , $9=$ Sultanate of Touggourt $(M), 10=$ Kingdom of Spain $(M), 11=$ Principality of Anhalt-Bernburg (M), $12=$ French Republic $(\mathrm{R}), 14=$ Kingdom of Great-Britain and Ireland in Personal Union with the Electorate of $\mathrm{Ha}(\mathrm{M}), 15=$ Kingdom of Naples $(\mathrm{M}), 18=$ Empire of Fez and Morocco $(\mathrm{M}), 19=$ Regency of Tunis $(\mathrm{M}), 23=$ Empire of All Russias (M) , 25 = Principality of Waldeck-Pyrmont (M) , $29=$ Kingdom of Portugal (M) , 31 = Principality of Hohenzollern-Sigmaringen $(M), 32=$ Duchy of Saxe-Hildburghausen $(M), 33=$ Kingdom of Sardinia $(M), 34=$ Electorate of Saxony $(M), 35=$ Duchy of Parma and Piacenza $(M), 36=$ Duchy of Mecklenburg-Schwerin $(M), 37=$ Kingdom of Prussia $(M)$ , 38 = Habsburg Monarchy (M), $39=$ Landgraviate of Hesse-Kassel (M) , $40=$ Republic of San Marino (R), $42=$ Sublime Ottoman State (M) , $47=$ Duchy of Brunswick (M) , $48=$ Co-Principality of Andorra under Spain and France $(\mathrm{M}), 49=$ Lordships of Lesser Kabylia (M) , 50 = Pashalik of Tripoli in Africa (M) , 51 = Electorate of Hanover in Personal union with the United Kingdom (M), 52 = Lordships of the House of Nassau (M), 53 = Landgraviate of Hesse-Darmstadt (M), $54=$ Duchy of Saxe-Gotha (M) , $55=$ Duchy of Saxe-Coburg (M) , $57=$ Principality of Svaneti (M) , $58=$ Kingdom of Sweden $(M), 59=$ Duchy of Saxe-Meiningen $(M), 61=$ Principality of Hohenzollern-Hechingen $(M), 62=$ Principality of Lippe $(M), 63=$ Duchy of Mecklenburg-Strelitz (M) , 64 = County of Wittgenstein $(M), 66=$ Island of Zakynthos $(M), 67=$ Imperial City of Frankfurt (R) , 68 = Imperial City of Lindau (R) , $69=$ Imperial City of Augsburg (R) , $71=$ Imperial City of Goslar (R), $72=$ Imperial City of Schweinfurt (R), 73 = Imperial City of Kaufbeuren (R), $74=$ Imperial City of Biberach (R), 75 = Prince-Bishopric of Passau (M) , $76=$ Imperial City of Memmingen (R), $77=$ Imperial City of Reutlingen (R), $78=$ Imperial City of Bremen (R), $79=$ Archbishopric of Salzburg (M), 80 = Imperial City of Nuremberg (R) , $81=$ Imperial City of Rothenburg (R), 82 = Imperial City of Ulm (R), 83 = Imperial City of Schwabisches Hall (R), $85=$ Imperial City of Buchhorn (R), 86 = Imperial City of Regensburg (R) , 87 = Imperial City of Rottweil (R) , $89=$ Imperial City of Kempten (R), $90=$ Principality of Liechtenstein (M), 91 = Imperial City of Wetzlar (R), $92=$ Imperial City of Hamburg (R), $93=$ Imperial City of Dortmund (R), $95=$ Duchy of Oldenburg (M) 
Figure B.9: European Monarchies, 1900

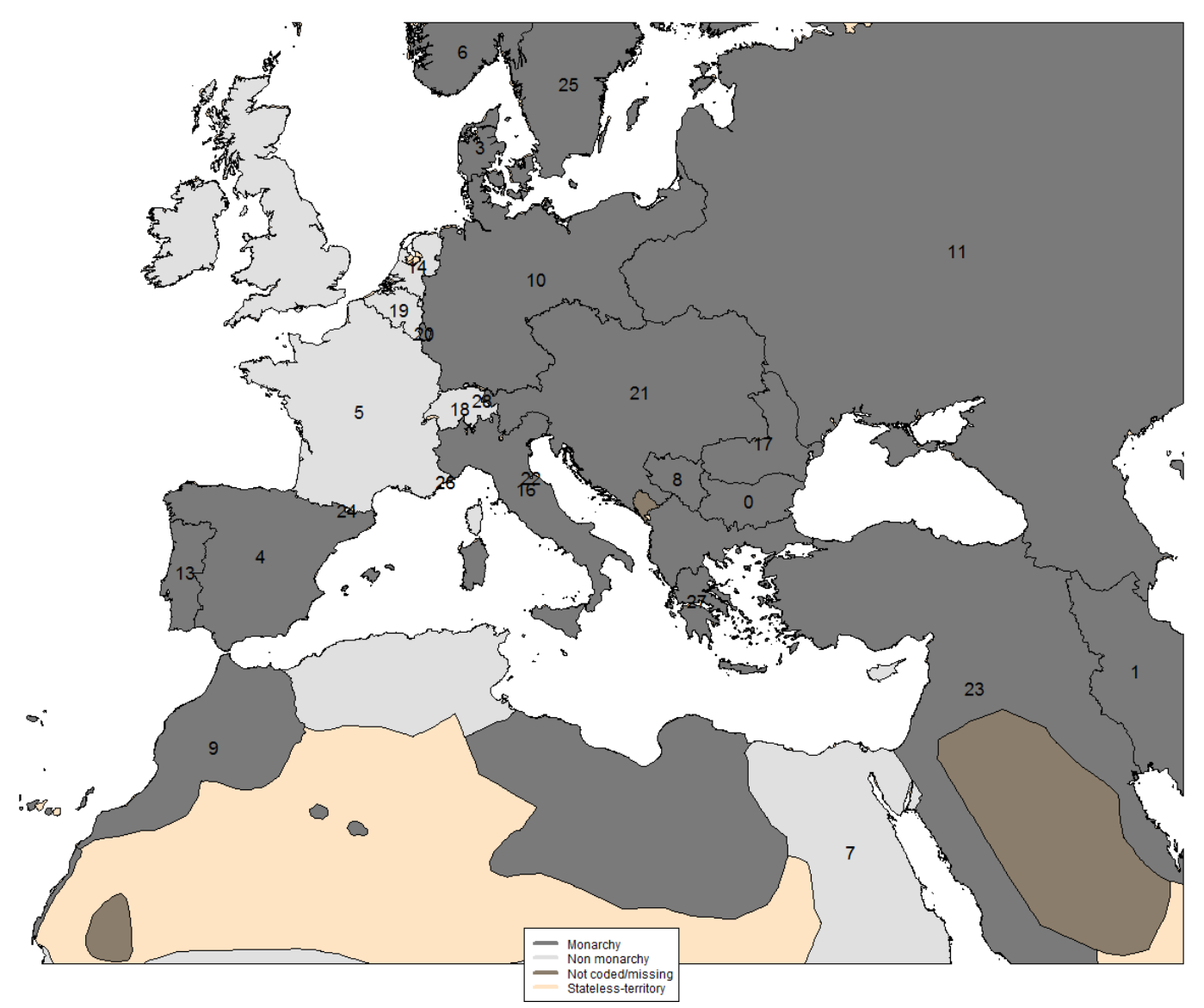

Coded states $(\mathbf{M}=$ monarchy, $\mathbf{R}=$ Republic): $0=$ Principality of Bulgaria $(M), 1=$ Qajar Empire of Persia $(M), 3=$ Kingdom of Denmark (M) , $4=$ Kingdom of Spain (M) , $5=$ French Republic (R), $6=$ United Kingdoms of Sweden and Norway $(M), 7=$ United Kingdom of Great-Britain and Ireland (R) , $8=$ Kingdom of Serbia (M) , $9=$ Sultanate of Morocco (M), $10=$ German Empire (M), $11=$ Empire of All Russias $(\mathrm{M}), 13=$ Kingdom of Portugal $(\mathrm{M}), 14=$ Kingdom of the Netherlands $(\mathrm{R}), 16=$ Kingdom of Italy (M) , $17=$ Kingdom of Romania (M) , $18=$ Swiss Confederation (R) , $19=$ Kingdom of Belgium (R) , $20=$ Grand Duchy of Luxembourg (M) , 21 = Austro-Hungarian Empire (M) , 22 = Republic of San Marino (R), 23 = Sublime Ottoman State (M), 24 = Co-Principality of Andorra under Spain and France (R), $25=$ United Kingdoms of Sweden and Norway (M) , 26 = Principality of Monaco (M), $27=$ Kingdom of Greece (M) , 28 = Principality of Liechtenstein (M) 
Figure B.10: European Monarchies, 2000

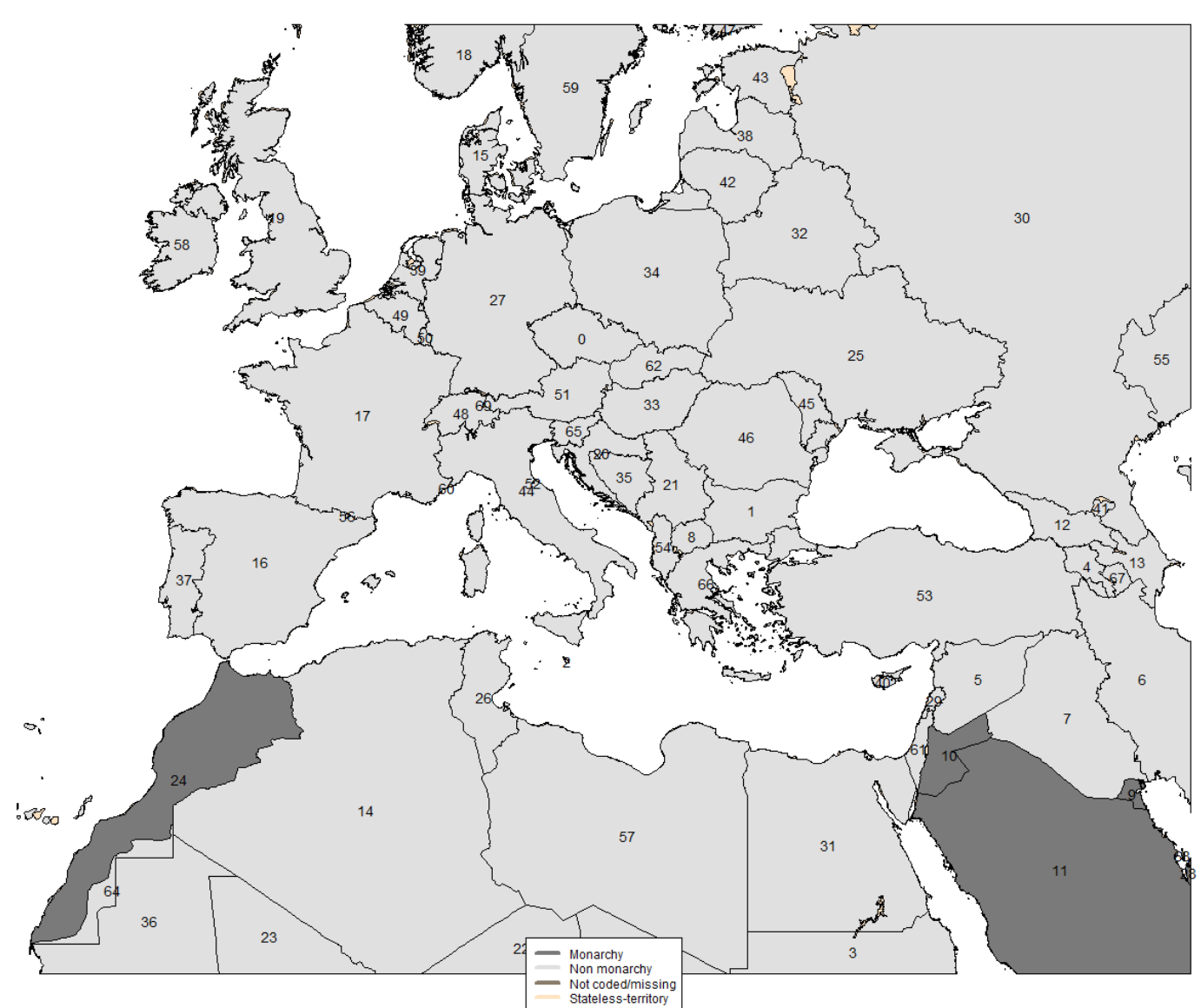

Coded states (M=monarchy, $\mathbf{R}=$ Republic): $0=$ Czech Republic $(\mathrm{R}), 1=$ Republic of Bulgaria $(\mathrm{R}), 2$ = Republic of Malta $(\mathrm{R})$, 3 = Republic of Sudan (R), 4 = Republic of Armenia (R), 5 = Syrian Arab Republic (R), 6 = Islamic Republic of Iran (R), $7=$ Republic of Iraq (R), 8 = Former Yugoslav Republic of Macedonia (R), $9=$ State of Kuwait (M), $10=$ The Hashemite Kingdom of Jordan (M), 11 = Kingdom of Saudi Arabia (M), 12 = Georgia (R), 13 = Republic of Azerbaijan (R), 14 = Democratic and Popular Republic of Algeria (R), 15 = Kingdom of Denmark (R), 16 = Kingdom of Spain (R), 17 = French Republic (R), $18=$ Kingdom of Norway (R), $19=$ United Kingdom of Great Britain and Northern Ireland (R), $20=$ Republic of Croatia (R), $21=$ Federal Republic of Yugoslavia (R), 22 = Republic of Niger (R), 23 = Republic of Mali (R), 24 = Kingdom of Morocco (M), $25=$ Ukraine (R), 26 = Republic of Tunisia (R), 27 = Federal Republic of Germany (R), 28 = State of Qatar (M), 29 = Republic of Lebanon (R), 30 = Russian Federation (R), $31=$ Arab Republic of Egypt (R), $32=$ Republic of Belarus (R), $33=$ Republic of Hungary (R), 34 = Republic of Poland (R), $35=$ Bosnia and Herzegovina (R), 36 = Islamic Republic of Mauritania (R), $37=$ Portuguese Republic (R), 38 = Republic of Latvia (R), $39=$ Kingdom of the Netherlands (R), $40=$ Republic of Cyprus (R), $41=$ Chechen Republic of Ichkeria (R), $42=$ Republic of Lithuania (R), 43 = Republic of Estonia (R), 44 = Italian Republic (R), $45=$ Republic of Moldova (R), $46=$ Romania (R), 47 = Republic of Finland (R), $48=$ Swiss Confederation (R), $49=$ Kingdom of Belgium (R), $50=$ Grand Duchy of Luxembourg (R), $51=$ Republic of Austria (R), $52=$ Most Serene Republic of San Marino (R), 53 = Republic of Turkey (R), 54 = Republic of Albania (R), 55 = Republic of Kazakstan (R), 56 = Co-Principality of Andorra under Spain and France (R), $57=$ Great Socialist People's Libyan Arab Jamahiriya (R), $58=$ Republic of Ireland (R), $59=$ Kingdom of Sweden (R), 60 = Principality of Monaco (M), 61 = State of Israel (R), 62 = Slovak Republic (R), 63 = Republic of Chad (R), 64 = Sahrawi Arab Democratic Republic (R), $65=$ Republic of Slovenia (R), $66=$ Hellenic Republic $(\mathrm{R}), 67=$ Nagorno-Karabakh Republic(R), 68 = Kingdom of Bahrain (M), 69 = Principality of Liechtenstein (M) 


\section{Appendix C: Global Monarchies, Mapped}

The global maps shown in the figures that follow adopt V-Dem country units (Coppedge et al. 2019) as starting points (for the period 1789-2005) and then merge on maps based on a link between V-DEM and different country polygon units (primarily GeaCron, along with a few other sources). To obtain codings of our key variable, Monarchy, we merged our global monarchy dataset to V-DEM units, and then to the different maps (where possible). This country to polygon mapping is not perfect since not all V-DEM units have an accompanying polygon, and some countries with polygons (from GeaCron) do not have a corresponding V-DEM unit.

Maps register year-to-year changes in the period from 1789-2005. Before 1789, we rely on GeaCron maps from 1700 and 1750, with the assumption that these maps are largely static in the intervening periods. That is, 1700-1749 is scored with the map for 1700, and 1750-1788 is scored with the 1750 map. We have made some adjustments to the maps below to make them as accurate as possible. 

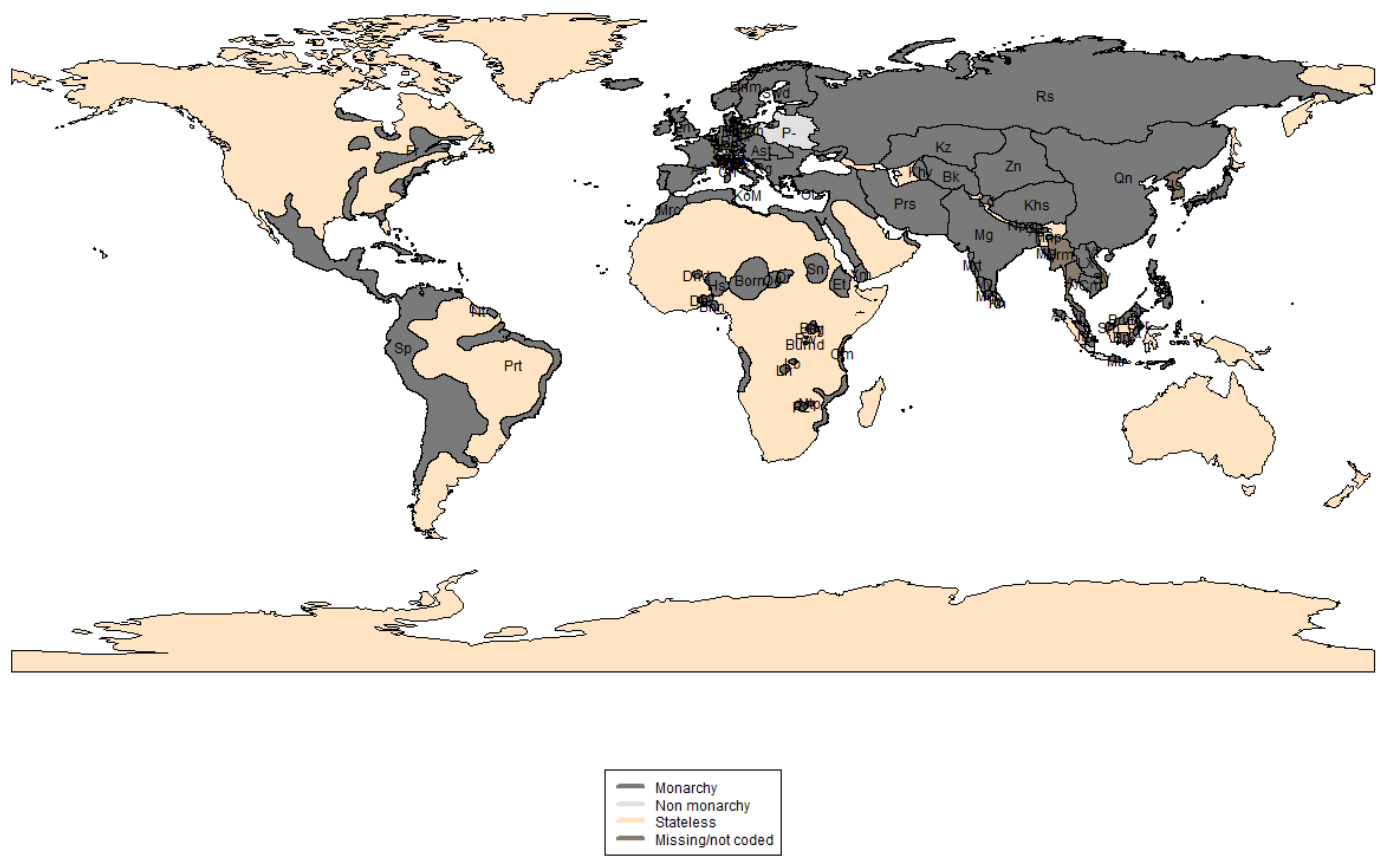

Coded states $(\mathbf{M}=$ monarchy, $\mathbf{R}=$ Republics): $A n=$ Andorra $(R), \operatorname{Rg}=$ Ragusa $(R)$, Brun $=$ Brunei $(M)$, Mnt $=$ Mantua $(M)$, Ms = Massa $(M), K z=\operatorname{Kazakh}(M)$, Ot $=$ Ottoman $(M)$, Dnd $=$ Dendi $(M)$, Mnp $=$ Manipur $(M)$, Mrt $=$ Maratha $(M)$, Ast $=$ Austria $(M), D h=$ Dahomey $(M), J p=\operatorname{Japan}(M), \operatorname{Ln}=$ Lunda $(M), J h=$ Johor $(M), \operatorname{Khv}=$ Khiva $(M), M U=M r a u k ~ U(M)$, Hs = Hausa $(M), S x=$ Saxony $(M)$, Burnd $=$ Burundi $(M), K n=$ Kandy $(M), J m=J a m b i(M)$, Gn $=$ Genoa $(R), \operatorname{Mrc}=$ Morocco $(M), \operatorname{Mtr}=$ Mataram $(M)$, Ts $=$ Tuscany $(M)$, Ber $=$ Berau $(M), \operatorname{Dr}=$ Darfur $(M), L b=$ Luba $(M), \operatorname{Sn}=\operatorname{Sennar}(M)$, $\mathrm{Rz}=\operatorname{Rozwi}(\mathrm{M}), \mathrm{Rw}=\mathrm{Rwanda}(\mathrm{M}), \mathrm{Vt}=\operatorname{Vietnam}(\mathrm{M}), \operatorname{Prs}=\operatorname{Persia}(\mathrm{M}), \mathrm{Bk}=$ Bukhara $(\mathrm{M}), \mathrm{My}=$ Mysore $(\mathrm{M}), \mathrm{Fr}=\mathrm{France}$ $(\mathrm{M}), \mathrm{Zn}=$ Zunghar $(\mathrm{M}), \mathrm{HRE}=$ Holy Roman Empire $(\mathrm{M}), \mathrm{Bv}=$ Bavaria $(\mathrm{M}), \mathrm{LX}=$ Lan Xang $(\mathrm{M})$, Dnm = Denmark $(\mathrm{M}), \mathrm{Ac}$ $=$ Aceh $(\mathrm{M}), \mathrm{Ym}=$ Yemen $(\mathrm{M}), \mathrm{Mdr}=$ Madurai $(\mathrm{M}), \mathrm{Pl}=$ Palembang $(\mathrm{M}), \mathrm{Qn}=\mathrm{Qing}(\mathrm{M}), \mathrm{Bnn}=$ Benin $(\mathrm{M}), \mathrm{PS}=$ Papal States $(\mathrm{R}), \mathrm{Cm}=$ Cambodia $(\mathrm{M}), \mathrm{Mg}=\operatorname{Mughal}(\mathrm{M}), \mathrm{Rs}=$ Russia $(\mathrm{M}), \mathrm{Bg}=$ Buganda $(\mathrm{M}), \mathrm{Lc}=\mathrm{Lucca}(\mathrm{R})$, Ass $=$ Assam $(\mathrm{M})$, En = England $(M), V n=$ Venice $(R), S l=$ Sulu $(M), P-=$ Poland-Lithuania $(R)$, Khs $=$ Khoshut $(M)$, Born = Bornu $(M), E t$ $=$ Ethiopia $(M)$, Bny $=$ Bunyoro $(M)$, Oy $=$ Oyo $(M), \operatorname{Prt}=$ Portugal $(M)$, Swd $=$ Sweden $(M)$, Od $=$ Ouaddai $(M), S m=$ Sambas $(M), B h=$ Bhutan $(M), K t=$ Kutai $(M), H n=\operatorname{Hanover}(M),=, B n j=\operatorname{Banjarmasin}(M), N p=N e p a l(M)$, Swt $=$ Switzerland (R), Mtp = Mutapa (M), Prm = Parma (M), Ld = Ladakh (M), Sp $=$ Spain $(M), N t=\operatorname{Netherlands~}(R)$ 


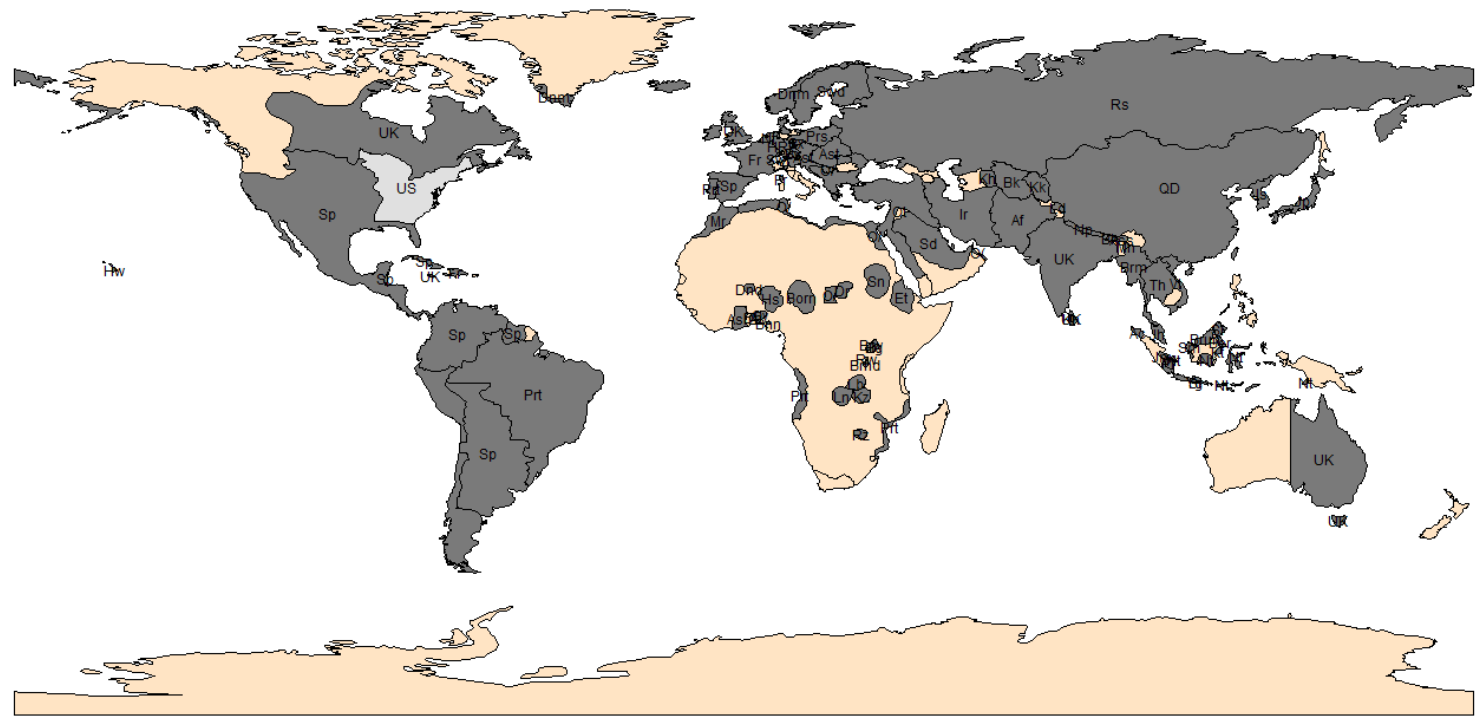

\section{- Monarchy
Non monarchy
Missinglnot coded
Statelos teritories}

Coded states (M=Monarchy, $\mathbf{R}=$ Republic): $\mathrm{Swt}_{\mathrm{w}}=$ Switzerland $(\mathrm{R}), \mathrm{Bh}=$ Bhutan $(\mathrm{M}), \mathrm{Sp}=\mathrm{Spain}(\mathrm{M})$, UK = United Kingdo $\mathrm{m}(\mathrm{M}), \operatorname{Prt}=$ Portugal $(\mathrm{M}), \operatorname{Ir}=\operatorname{Iran}(\mathrm{M}), \mathrm{Th}=$ Thailand $(\mathrm{M})$, Brun $=$ Brunei $(\mathrm{M}), \mathrm{QD}=$ Qing Dynasty $(\mathrm{M}), \mathrm{Mr}=\mathrm{Morocco}$ $(\mathrm{M}), \mathrm{O} /=$ Ottoman/Turkey $(\mathrm{M}), \mathrm{Nt}=$ Netherlands $(\mathrm{M}), \mathrm{Rw}=$ Rwanda $(\mathrm{M})$, Brnd $=$ Burundi $(\mathrm{M}), \mathrm{NZ}=$ New Zealand $(\mathrm{M})$, Ln = Lunda $(M), E t=$ Ethiopia $(M), B n=$ Bunyoro $(M), B g=$ Buganda $(M), A c=$ Aceh $(M)$, Brun $=$ Brunei $(M), J h=$ Johor $(\mathrm{M}), \mathrm{Vt}=\operatorname{Vietnam}(\mathrm{M}), \mathrm{Kk}=$ Kokand $(\mathrm{M}), \mathrm{Bk}=\operatorname{Bukhara}(\mathrm{M}), \mathrm{Dr}=\operatorname{Darfur}(\mathrm{M}), \mathrm{Jp}=\operatorname{Japan}(\mathrm{R}), \mathrm{Js}=\operatorname{Joseon}(\mathrm{M}), \mathrm{Kh}=\mathrm{Khi}$ va $(M), \operatorname{Rz}=\operatorname{Rozwi}(M), H w=$ Hawaii $(M), K t=\operatorname{Kutai}(M), \mathrm{Ld}=$ Ladakh $(\mathrm{M}), \mathrm{Jm}=\operatorname{Jambi}(\mathrm{M}), \mathrm{Yg}=\operatorname{Yogyakarta}(\mathrm{M}), \mathrm{Sr}=$ Surakarta $(\mathrm{M})$, Brm $=$ Burma $(M)$, Ber $=$ Berau $(M)$, Ass $=$ Assam $(M)$, Sn $=$ Sennar $(M)$, Ash $=$ Ashanti $(M), P l=P a l e m b a n g$ $(\mathrm{M}), \mathrm{Dh}=$ Dahomey $(\mathrm{M}), \mathrm{Oy}=\mathrm{Oyo}(\mathrm{M}), \mathrm{Sd}=\operatorname{Saudi}(\mathrm{M}), \mathrm{Np}=\operatorname{Nepal}(\mathrm{M}), \mathrm{Dn}=\operatorname{Denmark}(\mathrm{M})$, Swd $=$ Sweden $(\mathrm{M}), \mathrm{Kn}=$ Kandy $(M), M n=$ Manipur $(M), S m=$ Sambas $(M), \operatorname{Prs}=$ Prussia $(M), F r=$ France $(M), H s=$ Hausa $(M)$, Af $=$ Afghanistan $(\mathrm{M}), \mathrm{Rs}=$ Russia $(\mathrm{M}), \mathrm{O} /=$ Ottoman/Turkey $(\mathrm{M})$, US = United States (R) , O/ = Ottoman/Turkey (M) , Jh = Johor (M), Ast $=$ Austria $(\mathrm{M})$, Ast $=$ Austria $(\mathrm{M}), \mathrm{HRE}=$ Holy Roman Empire $(\mathrm{M}), \mathrm{Bv}=$ Bavaria $(\mathrm{M}), \mathrm{Sx}=$ Saxony $(\mathrm{M})$ 


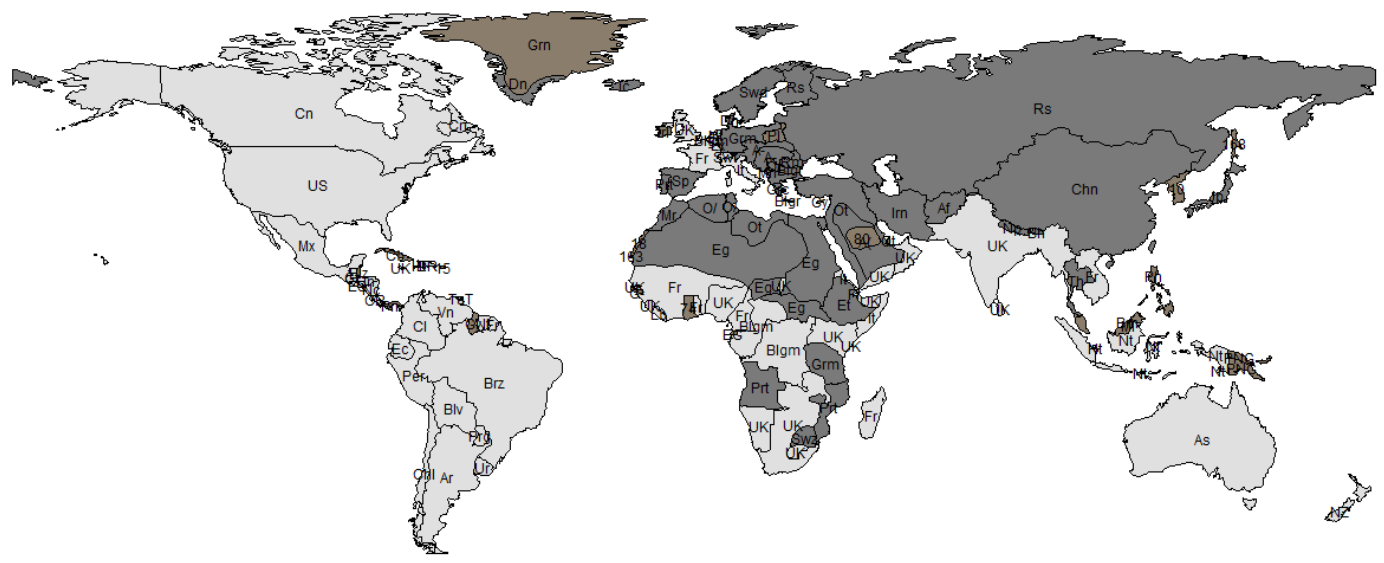

Coded states $(\mathbf{M}=$ monarchy, $\mathbf{R}=$ Republics $): \mathrm{Lx}=$ Luxembourg $(\mathrm{M})$, Swt $=$ Switzerland $(\mathrm{R}), \mathrm{Bh}=\mathrm{Bhutan}(\mathrm{M}), \mathrm{Qt}=\mathrm{Qatar}$ $(\mathrm{M}), \mathrm{US}=\operatorname{United}$ States $(\mathrm{R}), \mathrm{Ht}=\operatorname{Haiti}(\mathrm{R}), \mathrm{DR}=\operatorname{Dominican} \operatorname{Republic}(\mathrm{R}), \mathrm{UK}=$ United Kingdom $(\mathrm{R}), \mathrm{Nc}=\operatorname{Nicaragua}(\mathrm{R})$ , CR = Costa Rica $(\mathrm{R}), \mathrm{UK}=$ United $\operatorname{Kingdom}(\mathrm{R}), \mathrm{Lb}=$ Liberia $(\mathrm{R}), \mathrm{Blgm}=$ Belgium $(\mathrm{R})$, Prt $=$ Portugal, Blv $=$ Bolivia $(\mathrm{R})$, Prt $=$ Portugal $(M), F r=$ France $(R), U K=$ United Kingdom $(R)$, Chl $=$ Chile $(R), U K=$ United Kingdom $(R)$, Swz $=$ Swaziland $(\mathrm{M}), \mathrm{NZ}=\mathrm{New}$ Zealand $(\mathrm{R}), \operatorname{Ar}=$ Argentina $(\mathrm{R}), \mathrm{Ic}=\mathrm{Iceland}(\mathrm{R}),(\mathrm{R}), \mathrm{Blgm}=$ Belgium $(\mathrm{R}), \mathrm{Sp}=\mathrm{Spain}(\mathrm{M}), \operatorname{Prt}$ $=$ Portugal $(\mathrm{M}), \operatorname{Irn}=\operatorname{Iran}(\mathrm{M}), \mathrm{Af}=\operatorname{Afghanistan}(\mathrm{M}), \mathrm{Mx}=\operatorname{Mexico}(\mathrm{R}), \mathrm{Th}=$ Thailand $(\mathrm{M}), \mathrm{Gt}=$ Guatemala $(\mathrm{R}), \mathrm{Hn}=$ Honduras $(\mathrm{R}), \mathrm{ES}=\mathrm{El}$ Salvador $(\mathrm{R}), \mathrm{Cl}=$ Colombia $(\mathrm{R}), \mathrm{Nt}=$ Netherlands $(\mathrm{R}), \mathrm{Fr}=$ France $(\mathrm{R}), \mathrm{Ec}=$ Ecuador $(\mathrm{R}), \operatorname{Per}=$ Peru $(\mathrm{R}), \operatorname{Brz}=\operatorname{Brazil}(\mathrm{R}), \mathrm{As}=\operatorname{Australia}(\mathrm{R}), \mathrm{Ur}=\operatorname{Uruguay}(\mathrm{R}), \mathrm{Dn}=\operatorname{Denmark}(\mathrm{M}), \mathrm{Nt}=$ Netherlands $(\mathrm{R}), \mathrm{Np}=\mathrm{Nepal}$ $(\mathrm{M}), \mathrm{It}=\mathrm{Italy}(\mathrm{R}), \mathrm{Et}=$ Ethiopia $(\mathrm{M}), \mathrm{Fr}=$ France $(\mathrm{R}), \mathrm{Vn}=$ Venezuela $(\mathrm{R}), \mathrm{Brn}=$ Brunei $(\mathrm{M}), \mathrm{Cn}=\mathrm{Canada}(\mathrm{R})$, Swd $=$ Sweden $(\mathrm{M})$, Grc $=$ Greece $(\mathrm{M}), \mathrm{Blgr}=$ Bulgaria $(\mathrm{M}), \mathrm{O} /=$ Ottoman $/$ Turkey $(\mathrm{M}), \mathrm{It}=\mathrm{Italy}(\mathrm{R}), \mathrm{Rm}=$ Romania $(\mathrm{M}), \mathrm{Chn}=$ China $(\mathrm{M}), \mathrm{Eg}=$ Egypt $(\mathrm{M})$, Ot = Ottoman $(\mathrm{M}), \mathrm{Mr}=$ Morocco $(\mathrm{M}),(\mathrm{R}), \mathrm{Grm}=$ Germany $(\mathrm{M}), \mathrm{It}=\mathrm{Italy}(\mathrm{R}), \mathrm{Jp}=\mathrm{Japan}$ $(\mathrm{M}), \mathrm{A}(=$ Arabia $($ Nejd $)(\mathrm{M}), \mathrm{Blgr}=$ Bulgaria $(\mathrm{M}), \mathrm{Eg}=$ Egypt $(\mathrm{M}), \operatorname{Prg}=$ Paraguay $(\mathrm{R}), \mathrm{Dn}=\operatorname{Denmark}(\mathrm{M}), \mathrm{Nt}=$ Netherlands $(\mathrm{R}), \mathrm{Ot}=$ Ottoman $(\mathrm{M}), \mathrm{O} /=$ Ottoman/Turkey $(\mathrm{M}), \mathrm{Rs}=$ Russia $(\mathrm{M}), \mathrm{A}-\mathrm{=}$ Austria-Hungary $(\mathrm{M})$ 
Figure C.4: Global Monarchies, 2000
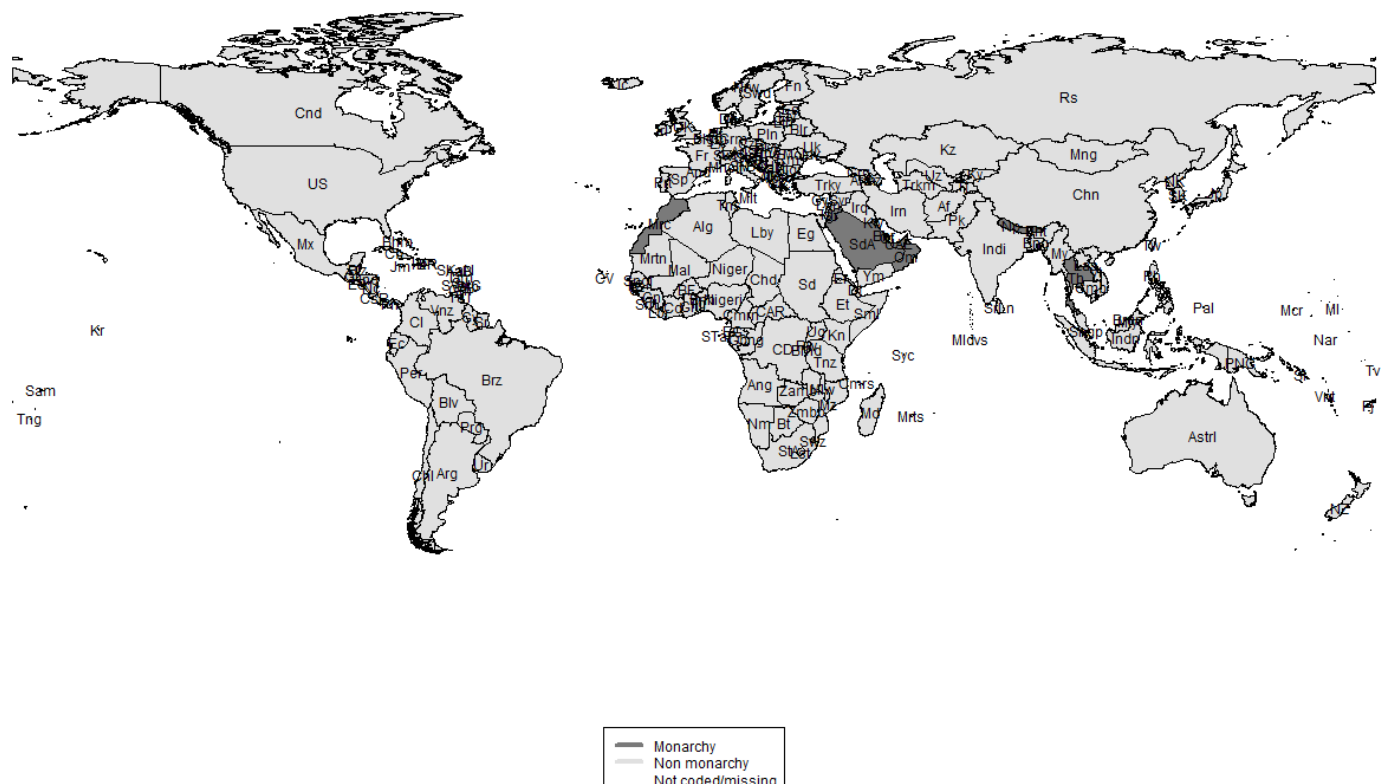

Coded states (M=monarchy, $\mathbf{R}=$ Republic): $\mathrm{Gy}=$ Guyana $(\mathrm{R}), \mathrm{Sr}=$ Suriname $(\mathrm{R}), \mathrm{Ta} \mathrm{T}=$ Trinidad and Tobago $(\mathrm{R}), \mathrm{Vnz}=\mathrm{V}$ enezuela $(\mathrm{R})$, Sam $=$ Samoa $(\mathrm{R})$, Tng $=$ Tonga $(\mathrm{M}), \operatorname{Arg}=$ Argentina $(\mathrm{R})$, Blv $=$ Bolivia $(\mathrm{R})$, Brz $=$ Brazil $(\mathrm{R})$, Chl $=$ Chile $(\mathrm{R})$, $\mathrm{Ec}=$ Ecuador $(\mathrm{R}), \operatorname{Prg}=$ Paraguay $(\mathrm{R}), \operatorname{Per}=\operatorname{Peru}(\mathrm{R}), \mathrm{Ur}=$ Uruguay $(\mathrm{R}), \mathrm{Gt}=$ Guatemala $(\mathrm{R}), \mathrm{Mx}=\mathrm{Mexico}(\mathrm{R}), \mathrm{Brb}=\mathrm{Bar}$ bados $(R), D m=$ Dominica $(R), G r n=$ Grenada $(R), S . L=$ St. Lucia $(R)$, SVatG $=$ St. Vincent and the Grenadines $(R), D R=$ Dominican Republic (R) , Ht = Haiti (R) , Jm = Jamaica (R), Bhm = Bahamas (R), Blz = Belize (R), Cl = Colombia (R), CsR = Costa Rica $(R), C b=$ Cuba $(R), E S=E l$ Salvador $(R), \operatorname{Hnd}=$ Honduras $(R), N c=$ Nicaragua $(R)$, Pn $=$ Panama $(R), A a B=A$ ntigua and Barbuda $(\mathrm{R})$, SKaN = St. Kitts and Nevis $(\mathrm{R})$, Ic = Iceland $(\mathrm{R}), \operatorname{Irl}=$ Ireland $(\mathrm{R}), \mathrm{UK}=$ United Kingdom $(\mathrm{R}), \mathrm{CV}=$ Cape Verde $(\mathrm{R}), \mathrm{Cd}=$ Cote d'Ivoire $(\mathrm{R}), \mathrm{Gh}=$ Ghana $(\mathrm{R})$, Lbr = Liberia $(\mathrm{R})$, Prt = Portugal $(\mathrm{R}), \mathrm{Sp}=\mathrm{Spain}(\mathrm{R}), \mathrm{BF}=\mathrm{Burkin}$ a Faso $(\mathrm{R}), \mathrm{Gn}=$ Guinea $(\mathrm{R}), \mathrm{G}-=$ Guinea-Bissau $(\mathrm{R}), \mathrm{Mal}=$ Mali $(\mathrm{R}), \mathrm{Sngl}=$ Senegal $(\mathrm{R})$, SrrL $=$ Sierra Leone $(\mathrm{R}), \mathrm{TG}=\mathrm{Th}$ e Gambia $(R), D j=$ Djibouti $(R), E r=$ Eritrea $(R), E t=$ Ethiopia $(R), \operatorname{Mng}=$ Mongolia $(R), S d=$ Sudan $(R), U g=\operatorname{Uganda}(R)$ , $\operatorname{Irq}=\operatorname{Iraq}(R), J r=\operatorname{Jordan}(M), K z=$ Kazakhstan $(R), \operatorname{Nrw}=\operatorname{Norway}(R), R s=$ Russia $(R)$, Swd $=$ Sweden $(R)$, Alg = Algeri $\mathrm{a}(\mathrm{R})$, And = Andorra $(\mathrm{R}), \mathrm{Cmrn}=$ Cameroon $(\mathrm{R}), \mathrm{CAR}=$ Central African Republic $(\mathrm{R})$, Mnc $=$ Monaco $(\mathrm{M})$, Tns $=$ Tunisia ( $\mathrm{R}), \mathrm{Bnn}=$ Benin $(\mathrm{R}), \mathrm{EG}=$ Equatorial Guinea $(\mathrm{R}), \mathrm{Kr}=$ Kiribati $(\mathrm{R})$, Niger $=$ Niger $(\mathrm{R})$, Nigeri $=$ Nigeria $(\mathrm{R}), \mathrm{STaP}=\mathrm{Sao} \mathrm{T}$ ome and Principe $(\mathrm{R}), \mathrm{Tg}=\operatorname{Togo}(\mathrm{R}), \mathrm{Alb}=$ Albania $(\mathrm{R}), \mathrm{BaH}=$ Bosnia and Herzegovina $(\mathrm{R}), \mathrm{Cr}=$ Croatia $(\mathrm{R}), \mathrm{It}=\mathrm{Italy}(\mathrm{R})$, Mcd $=$ Macedonia $(R)$, Mlt = Malta $(R), S M=$ San Marino $(R)$, Blgr $=$ Bulgaria $(R)$, Cy $=$ Cyprus $(R)$, Grg $=$ Georgia $(R)$, Grc $=$ Greece $(\mathrm{R}), \mathrm{Lbn}=$ Lebanon $(\mathrm{R})$, Trky $=$ Turkey $(\mathrm{R})$, Austr $=$ Austria $(\mathrm{R})$, CzR $=$ Czech Republic $(\mathrm{R})$, Dn $=$ Denmark $(\mathrm{R})$, Hng $=$ Hungary $(R)$, Pln $=$ Poland $(R)$, Slvk = Slovakia $(R)$, Slvn = Slovenia $(R)$, Blgm = Belgium $(R)$, Fr $=$ France $(R), L c=$ Liechtenstein $(\mathrm{M}), \mathrm{Lx}=\operatorname{Luxembourg}(\mathrm{R}), \mathrm{Nt}=$ Netherlands $(\mathrm{R})$, Swt $=$ Switzerland $(\mathrm{R}), \mathrm{Blr}=$ Belarus $(\mathrm{R})$, Es $=$ Estonia $(\mathrm{R})$, Fn $=$ Finland $(R), \operatorname{Ltv}=$ Latvia $(R)$, Lth $=$ Lithuania $(R), \operatorname{Moldv}=$ Moldova $(R), R m=$ Romania $(R)$, Uk = Ukraine $(R)$, Mldvs $=$ Maldives $(\mathrm{R}), \mathrm{Om}=\operatorname{Oman}(\mathrm{M}), \mathrm{Sml}=$ Somalia $(\mathrm{R}), \operatorname{SrLn}=\operatorname{Sri} \operatorname{Lanka}(\mathrm{R}), \operatorname{Trkm}=$ Turkmenistan $(\mathrm{R}), \mathrm{Uz}=\operatorname{Uzbekistan}(\mathrm{R})$, Ym $=$ Yemen $(R), \operatorname{Arm}=$ Armenia $(R), A z=$ Azerbaijan $(R), \operatorname{Bhr}=$ Bahrain $(M), \operatorname{Irn}=\operatorname{Iran}(R), K w=$ Kuwait $(M)$, Qt $=$ Qat ar $(M), S d A=$ Saudi Arabia $(M)$, UAE $=$ United Arab Emirates $(M), A f=$ Afghanistan $(R), K y=$ Kyrgyzstan $(R), N p=N e p a l$ $(\mathrm{M}), \mathrm{Pk}=\operatorname{Pakistan}(\mathrm{R}), \mathrm{T} j=$ Tajikistan $(\mathrm{R}), \mathrm{Bng}=$ Bangladesh $(\mathrm{R})$, Bht $=$ Bhutan $(\mathrm{M})$, Brun $=$ Brunei $(\mathrm{M}), \mathrm{Jp}=\mathrm{Japan}(\mathrm{R}), \mathrm{N}$ $\mathrm{K}=$ North Korea $(\mathrm{R}), \mathrm{Pal}=$ Palau $(\mathrm{R}), \mathrm{Ph}=$ Philippines $(\mathrm{R}), \mathrm{SK}=$ South Korea $(\mathrm{R}), \mathrm{Cmb}=$ Cambodia $(\mathrm{R})$, Las $=$ Laos $(\mathrm{R})$, My = Myanmar $(R), T h=$ Thailand $(M), V t=\operatorname{Vietnam~}(R), M I=$ Marshall Is. $(R)$, Mcr $=$ Micronesia $(R), B t=$ Botswana $(R)$, Brnd = Burundi $(\mathrm{R}), \mathrm{Kn}=$ Kenya $(\mathrm{R}), \mathrm{Rw}=\mathrm{Rwanda}(\mathrm{R}), \mathrm{Zamb}=$ Zambia $(\mathrm{R}), \mathrm{Zmbb}=$ Zimbabwe $(\mathrm{R})$, Cmrs $=$ Comoros $(\mathrm{R})$ , Lst $=$ Lesotho $(\mathrm{R}), \mathrm{Mlw}=$ Malawi $(\mathrm{R}), \mathrm{Mz}=\operatorname{Mozambique}(\mathrm{R}), \mathrm{StA}=$ South Africa $(\mathrm{R})$, Swz $=$ Swaziland $(\mathrm{M})$, Ang = Angola $(\mathrm{R}), \mathrm{Cng}=$ Congo $(\mathrm{R}), \mathrm{CD}=$ Congo, $\mathrm{DRC}(\mathrm{R}), \mathrm{Fj}=\mathrm{Fiji}(\mathrm{R}), \mathrm{Gb}=$ Gabon $(\mathrm{R}), \mathrm{Nm}=$ Namibia $(\mathrm{R}), \mathrm{NZ}=\mathrm{New}$ Zealand $(\mathrm{R})$, 
Md = Madagascar (R), Mrts = Mauritius (R), Syc $=$ Seychelles $(\mathrm{R})$, Astrl = Australia $(\mathrm{R})$, Nar $=$ Nauru (R), PNG = Papua New Guinea $(\mathrm{R}), \mathrm{SI}=$ Solomon Is. $(\mathrm{R}), \mathrm{Tv}=$ Tuvalu $(\mathrm{R}), \mathrm{Vnt}=$ Vanuatu $(\mathrm{R})$, Cnd $=$ Canada $(\mathrm{R}), \mathrm{Grm}=$ Germany $(\mathrm{R}), \mathrm{Tw}=\mathrm{Taiw}$ an $(\mathrm{R})$, Chn = China $(\mathrm{R})$, Mly = Malaysia $(\mathrm{R}), \operatorname{Sngp}=\operatorname{Singapore}(\mathrm{R})$, Indn = Indonesia $(\mathrm{R})$, Lby = Libya $(\mathrm{R})$, Chd $=$ Chad $(\mathrm{R})$, Is $=$ Israel $(R), \operatorname{Syr}=\operatorname{Syria}(R), \operatorname{Eg}=\operatorname{Egypt}(R), \operatorname{Indi}=\operatorname{India}(R), \operatorname{SaM}=\operatorname{Serbia}$ and Montenegro $(R)$, US $=$ United States $(R)$, $\operatorname{Tnz}=$ Tanzania $(\mathrm{R}), \operatorname{Mrc}=\operatorname{Morocco}(\mathrm{M}), \operatorname{Mrtn}=$ Mauritania $(\mathrm{R})$ 
Appendix D: Data 
Table D.1: Variables

\begin{tabular}{|c|c|c|c|c|c|c|}
\hline NAME & LABEL & DEFINITION & SOURCE & SCOPE & SCALE & TABLE \\
\hline Monarchy & monarchy_veenendaal & Monarchy index (described in text). & Authors & World & Dichotomous & All \\
\hline $\begin{array}{l}\text { Conflict } \\
\text { (cumulative) }\end{array}$ & conflict_cbd_ln & $\begin{array}{l}\text { Cumulative number of violent conflicts } \\
\text { involving a state over a century }\end{array}$ & $\begin{array}{l}\text { Dincecco, } \\
\text { Onorato }(2018)\end{array}$ & Europe & Logarithmic & 5 \\
\hline $\begin{array}{l}\text { Conflict } \\
\text { (binary) }\end{array}$ & conflict & $\begin{array}{l}\text { Coded } 1 \text { if violent conflict involving } \\
\text { that state occurred in a century }\end{array}$ & $\begin{array}{l}\text { Dincecco, } \\
\text { Onorato (2018) }\end{array}$ & Europe & Dichotomous & 5 \\
\hline Border length & length_ln & Length of state borders. & Authors & Europe & Logarithmic & 5 \\
\hline Edge & is_edge & $\begin{array}{l}\text { Coded } 1 \text { if state lies at the edge of the } \\
\text { EurAtlas map of Europe, hence does } \\
\text { not have a complete set of borders. }\end{array}$ & Authors & Europe & Dichotomous & 5 \\
\hline Neighbors & n_neighbors_ln & $\begin{array}{l}\text { Number of neighboring (contiguous) } \\
\text { states. }\end{array}$ & Authors & Europe & Logarithmic & 5 \\
\hline Area (Europe) & larea & Territory size, in Sq. Km. & Authors & Europe & Logarithmic & 5 \\
\hline State & state_num & $\begin{array}{l}\text { Coded } 1 \text { if territory is ruled by a state- } \\
\text { like form of political organization. }\end{array}$ & Authors & Europe & Logarithmic & 5 \\
\hline Area (World) & area_imp_ext_empires_l & $n$ Territory & Authors & World & Logarithmic & 6 \\
\hline Radios & e_radio_n_ipo_ln & $\begin{array}{l}\text { Number of radios, missing values } \\
\text { within a time-series interpolated. }\end{array}$ & $\begin{array}{l}\text { Comin, Hobijn } \\
(2009)\end{array}$ & World & Logarithmic & 6 \\
\hline Regions & e_regionpol & $\begin{array}{l}\text { Region dummies for Eastern Europe \& } \\
\text { Central Asia, Latin America, Middle } \\
\text { East \& North Africa, Sub-Saharan } \\
\text { Africa, Western Europe \& North } \\
\text { America, East Asia, South-East Asia, } \\
\text { South Asia, Pacific, Caribbean }\end{array}$ & $\begin{array}{l}\text { V-Dem } \\
\text { (Coppedge et al. } \\
\text { 2018) }\end{array}$ & World & Dichotomous & 6 \\
\hline Population & e_mipopula_ln & Total population. & $\begin{array}{l}\text { V-Dem } \\
\text { (Coppedge et al. } \\
\text { 2018) }\end{array}$ & World & Logarithmic & 6 \\
\hline $\begin{array}{l}\text { Democracy } \\
\text { (binary) }\end{array}$ & e_mibmr & Coded 1 if democratic, 0 otherwise. & $\begin{array}{l}\text { Boix, Miller, } \\
\text { Rosato (2013) }\end{array}$ & World & Dichotomous & 6 \\
\hline $\begin{array}{l}\text { Party } \\
\text { dictatorship }\end{array}$ & guf_party & $\begin{array}{l}\text { Binary indicator of party regime type } \\
\text { (party-based, party-personal, party- } \\
\text { military, party-personal-military, } \\
\text { oligarchy, and Iran 1979-2010) }\end{array}$ & $\begin{array}{l}\text { Geddes, Wright, } \\
\text { Frantz (2014) }\end{array}$ & World & Dichotomous & 6 \\
\hline $\begin{array}{l}\text { Military } \\
\text { dictatorship }\end{array}$ & gwf_military & $\begin{array}{l}\text { Binary indicator of military regime type } \\
\text { (groups military, military-personal, } \\
\text { indirect military) }\end{array}$ & $\begin{array}{l}\text { Geddes, Wright, } \\
\text { Frantz (2014) }\end{array}$ & World & Dichotomous & 6 \\
\hline $\begin{array}{l}\text { Personal } \\
\text { dictatorship }\end{array}$ & guf_personal & $\begin{array}{l}\text { Binary indicator of personalist regime } \\
\text { type }\end{array}$ & $\begin{array}{l}\text { Geddes, Wright, } \\
\text { Frantz (2014) }\end{array}$ & World & Dichotomous & 6 \\
\hline $\begin{array}{l}\text { Natural } \\
\text { resources }\end{array}$ & $\begin{array}{l}\text { e_Total_Resources } \\
\text { Income_PC }\end{array}$ & $\begin{array}{l}\text { Resources obtained from mineral } \\
\text { wealth as a share of population. }\end{array}$ & $\begin{array}{l}\text { Haber, Menaldo } \\
\text { (2011) }\end{array}$ & World & Linear & 6 \\
\hline GDP per cap & e_migdppcln_ipo & Gross domestic product per capita. & $\begin{array}{l}\text { Bolt, van } \\
\text { Zanden (2014) }\end{array}$ & World & Logarithmic & 6 \\
\hline $\begin{array}{r}\text { English } \\
\text { colony }\end{array}$ & English_legal_origin & $1=$ former British colony, 0 otherwise. & $\begin{array}{l}\text { La Porta et al. } \\
(1999)\end{array}$ & World & Dichotomous & 6 \\
\hline Muslim & Muslim & $\begin{array}{l}\text { Share of population with Muslim } \\
\text { heritage. }\end{array}$ & Authors & World & Linear & 6 \\
\hline Protestant & Protestant & $\begin{array}{l}\text { Share of population with Protestant } \\
\text { heritage. }\end{array}$ & Authors & World & Linear & 6 \\
\hline Urbanization & e_miurbani & $\begin{array}{l}\text { Urbanization rate, i.e., ratio of urban } \\
\text { population to total population. }\end{array}$ & $\begin{array}{l}\text { V-Dem } \\
\text { (Coppedge et al. } \\
\text { 2018) }\end{array}$ & World & Linear & 6 \\
\hline
\end{tabular}


Table D.2: Descriptive Statistics

\begin{tabular}{|c|c|c|c|c|c|}
\hline Variable & Obs & Mean & Std. Dev. & Min & Max \\
\hline Monarchy & 19,934 & 0.28 & 0.45 & 0.00 & 1.00 \\
\hline Conflict (cumulative) & 842 & 0.31 & 0.82 & 0.00 & 5.30 \\
\hline Conflict (binary) & 842 & 0.12 & 0.33 & 0.00 & 1.00 \\
\hline Border length & 842 & 13.40 & 1.53 & 8.02 & 17.85 \\
\hline Edge & 842 & 0.07 & 0.25 & 0.00 & 1.00 \\
\hline Neighbors & 842 & 1.11 & 0.82 & 0.00 & 4.23 \\
\hline Area (Europe) & 838 & 22.85 & 2.54 & 13.34 & 29.00 \\
\hline State & 712 & 0.93 & 0.26 & 0.00 & 1.00 \\
\hline Area (World) & 44,078 & 2.55 & 2.15 & 0.00 & 10.48 \\
\hline Radios & 11,974 & 4.20 & 3.60 & 0.00 & 13.28 \\
\hline Population & 23,328 & 14.67 & 2.27 & 7.22 & 21.01 \\
\hline Democracy (binary) & 15,739 & 0.32 & 0.47 & 0.00 & 1.00 \\
\hline Party dictatorship & 7,891 & 0.29 & 0.45 & 0 & 1 \\
\hline Military dictatorship & 7,891 & 0.07 & 0.26 & 0 & 1 \\
\hline Personal dictatorship & 7,891 & 0.15 & 0.35 & 0 & 1 \\
\hline Natural resources per cap & 10,646 & 595.41 & 3228.97 & 0.00 & 81161.85 \\
\hline GDP per cap & 17,932 & 7.51 & 1.01 & 5.32 & 10.67 \\
\hline English colonial heritage & 40,605 & 0.34 & 0.47 & 0.00 & 1.00 \\
\hline Muslim & 40,821 & 23.29 & 35.98 & 0.00 & 99.90 \\
\hline Protestant & 41,037 & 12.73 & 22.93 & 0.00 & 98.00 \\
\hline Urbanization & 20,764 & 0.35 & 0.25 & 0.01 & 1.00 \\
\hline
\end{tabular}

Includes all variables in Table D.1 except nominal variables (multiple dummies). 
Table D.3: Descriptive statistics for regime breakdown analysis

\begin{tabular}{|c|c|c|c|c|c|}
\hline \multicolumn{6}{|c|}{ (1) } \\
\hline & Obs. & Mean & $\mathrm{SD}$ & Min & Max \\
\hline Monarchy & 19934 & .2672983 & .4425611 & 0 & 1 \\
\hline Regime change & 29909 & .0601491 & .2377669 & 0 & 1 \\
\hline Polyarchy & 22295 & .2831254 & .2583326 & .0084456 & .948767 \\
\hline Polyarchy sq. & 22295 & .1468927 & .2256154 & .0000713 & 9001589 \\
\hline GDP growth & 17172 & 1.454185 & 6.52284 & -68.93767 & 189.7407 \\
\hline L(GDP pc) & 17468 & 7.707957 & 1.051476 & 5.139029 & 11.34342 \\
\hline L(population) & 20835 & 10.812 & 3.25006 & 4.094345 & 21.00888 \\
\hline Duration & 29909 & 26.8461 & 40.05502 & 0 & 717 \\
\hline Duration2 & 29909 & 2325.064 & 13048.44 & 0 & 514089 \\
\hline Duration3 & 29909 & 464917.5 & 7794240 & 0 & $3.69 \mathrm{e}+08$ \\
\hline
\end{tabular}




\section{Appendix E: Additional figures}

Figure E1: Median size of monarchies / median size of non-monarchies in Europe and globally, 1100-2005

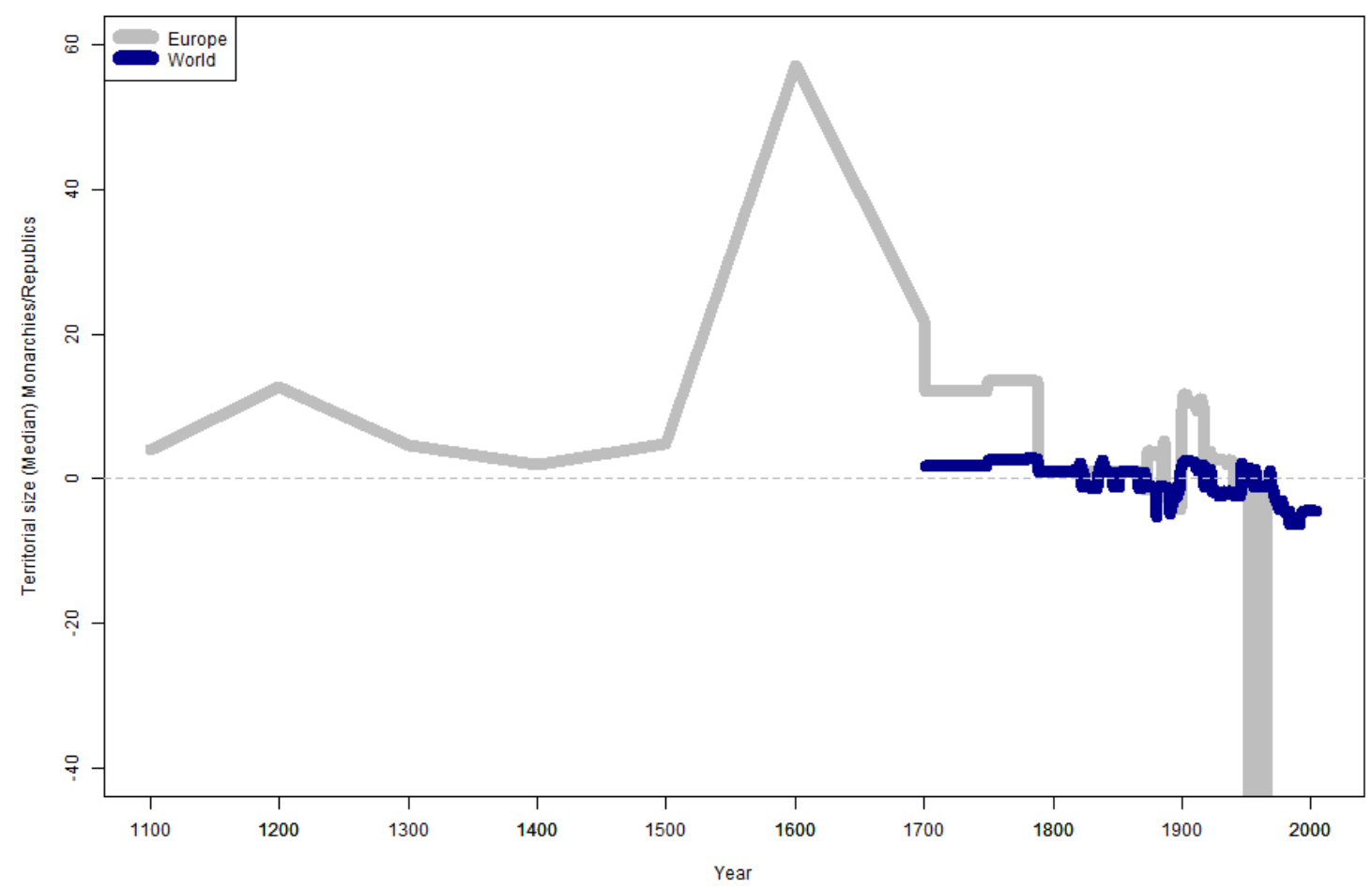




\section{Appendix References}

Aldrich, Robert, Cindy McCreery (eds). 2016. Crowns and Colonies: European Monarchies and Overseas Empires. Manchester: Manchester University Press.

Boix, Carles, Michael Miller, Sebastian Rosato. 2013. "A Complete Dataset of Political Regimes, 1800-2007." Comparative Political Studies 46, 1523-54.

Bolt, Jutta, Jan Luiten van Zanden. 2014. "The Maddison Project: collaborative research on historical national accounts." The Economic History Review 67.3: 627-651.

Boucoyannis, Deborah A. 2017. From Roving to Stationary Judges: Power, Land, Justice, and the Origins of Representative Institutions. Cambridge: Cambridge University Press.

Comin, Diego, Bart Hobijn. 2009. "Cross-country Historical Adoption of Technology (CHAT) dataset.” NBER Working Paper 15319.

Coppedge, Michael, John Gerring, Staffan I. Lindberg, Svend-Erik Skaaning, Jan Teorell, David Altman, Michael Bernhard, M. Steven Fish, Adam Glynn, Allen Hicken, Carl Henrik Knutsen, Kyle L. Marquardt, Kelly McMann, Valeriya Mechkova, Pamela Paxton, Daniel Pemstein, Laura Saxer, Brigitte Seim, Rachel Sigman, and Jeffrey Staton. 2017. "V-Dem Codebook v7.1." Varieties of Democracy (V-Dem) Project.

Coppedge, Michael, John Gerring, Carl Henrik Knutsen, Staffan I. Lindberg, Jan Teorell, Vlad Ciobanu, and Lisa Gastaldi. 2019. "V-Dem Country Coding Units v9" Varieties of Democracy (V-Dem) Project.

Elliott, John Huxtable. 1992. “A Europe of Composite Monarchies.” Past, Present 137 (November): 48-71.

Epstein, Stephan R. 1999. “The rise and decline of Italian city-states.” Working paper 51/99, London School of Economics. http://eprints.lse.ac.uk/22389/1/wp51.pdf

Geddes, Barbara, Joseph Wright, Erica Frantz. 2014. "Autocratic breakdown and regime transitions: A new data set." Perspectives on Politics 12.2: 313-331.

Grant, A., K. Stringer (eds). 1995. Uniting the Kingdom? The Making of British History. London: Routledge.

Graves, Michael A.R. 2001. The Parliaments of Early Modern Europe. Harlow, UK: Pearson.

Haber, Stephen, Victor Menaldo. 2011. "Do natural resources fuel authoritarianism? A reappraisal of the resource curse." American political science Review 105.1: 1-26.

Hansen, Mogens Herman (ed). 2000. A comparative study of thirty city-state cultures: an investigation. Copenhagen: Royal Danish Academy of Sciences and Letters.

La Porta, Rafael, Florencio Lopez-de-Silanes, Andrei Shleifer, Robert W. Vishny. 1999. "The Quality of Government." Journal of Economics, Law and Organization 15:1, 222-79.

Machiavelli, Niccolo. 1990. Florentine Histories, trans. Laura F. Banfield, Harvey C. Mansfield. Princeton: Princeton University Press.

Marongiu, Antonio. 1968. Medieval Parliaments: A Comparative Study. London: Eyre, Spottiswoode.

Monahan, Arthur P. 1987. Consent, Coercion, and Limit: The Medieval Origins of Parliamentary Democracy. Carleton University Press.

Myers, A. R. 1975. Parliaments and estates in Europe to 1789. Thames, Hudson. 
Nussli, Christos. 2017. "Euratlas Historical Atlas and Gazetteer of Europe."

Ober, Josiah. 2015. The Rise and Fall of Classical Greece. Princeton. Princeton University Press.

Stasavage, David. 2010. "When Distance Mattered: Geographic Scale and the Development of European Representative Assemblies.” American Political Science Review (forthcoming).

Stasavage, David. 2011. States of Credit: Size, Power, and the Development of European Polities. Princeton: Princeton University Press.

Stasavage, David. 2016. "Representation and Consent Why They Arose in Europe and Not Elsewhere." Annual Review of Political Science (forthcoming).

Van Zanden, Jan Luiten, Eeltjo Buringh, Maarten Bosker. 2010. "The Rise and Decline of European Parliaments, 1188-1789.” Economic History Review, 65(3): 835-61. 